\title{
Brug of kloof?
}

Citation for published version (APA):

de Vries, R., \& van der Velden, R. K. W. (2005). Brug of kloof? De ervaringen van HAVO- en VWOschoolverlaters over de aansluiting tussen VO en HO voor en na de invoering tweede fase VO. Researchcentrum voor Onderwijs en Arbeidsmarkt, Faculteit der Economische Wetenschappen. ROA Reports No. 008 https://doi.org/10.26481/umarep.2005008

Document status and date:

Published: 01/01/2005

DOI:

10.26481/umarep.2005008

Document Version:

Publisher's PDF, also known as Version of record

\section{Please check the document version of this publication:}

- A submitted manuscript is the version of the article upon submission and before peer-review. There can be important differences between the submitted version and the official published version of record.

People interested in the research are advised to contact the author for the final version of the publication, or visit the DOI to the publisher's website.

- The final author version and the galley proof are versions of the publication after peer review.

- The final published version features the final layout of the paper including the volume, issue and page numbers.

Link to publication

\footnotetext{
General rights rights.

- You may freely distribute the URL identifying the publication in the public portal. please follow below link for the End User Agreement:

www.umlib.nl/taverne-license

Take down policy

If you believe that this document breaches copyright please contact us at:

repository@maastrichtuniversity.nl

providing details and we will investigate your claim.
}

Copyright and moral rights for the publications made accessible in the public portal are retained by the authors and/or other copyright owners and it is a condition of accessing publications that users recognise and abide by the legal requirements associated with these

- Users may download and print one copy of any publication from the public portal for the purpose of private study or research.

- You may not further distribute the material or use it for any profit-making activity or commercial gain

If the publication is distributed under the terms of Article $25 \mathrm{fa}$ of the Dutch Copyright Act, indicated by the "Taverne" license above, 


\section{Brug of kloof?}

\section{De ervaringen van HAVO- en VWO-schoolverlaters over de aansluiting tussen $\mathrm{VO}$ en $\mathrm{HO}$ vóór en ná de invoering tweede fase $\mathrm{VO}$}

ROA-R-2005/8

Robert de Vries

Rolf van der Velden

Researchcentrum voor Onderwijs en Arbeidsmarkt

Faculteit der Economische Wetenschappen en Bedrijfskunde Universiteit Maastricht

Maastricht, september 2005 
ISBN 90-5321-419-4

Sec05.094 


\section{Inhoud}

Samenvatting en conclusie

1 Inleiding 1

2 Doorstroom naar het hoger onderwijs 5

3 Aansluiting tussen gevolgde opleiding en vervolgopleiding $\quad 7$

4 Algemene vaardigheden $\quad 15$

5 De keuze voor de vervolgopleiding achteraf gezien 31

6 Uitval in de vervolgopleiding $\quad 35$

7 Keuze van het vakkenpakket/profiel $\quad 41$

8 Hulp bij studie- of beroepskeuze $\quad 45$

Bijlage $\quad 51$ 



\section{Samenvatting en conclusie}

Centraal in dit rapport staat de vraag hoe HAVO- en VWO-schoolverlaters de aansluiting tussen het voortgezet en hoger onderwijs ervaren voor en na de invoering van de tweede fase. Hiervoor zijn de antwoorden van gediplomeerde schoolverlaters van het HAVO/VWO oude stijl (d.w.z. voor de invoering van de tweede fase) vergeleken met die van gediplomeerde schoolverlaters van het HAVO/NWO nieuwe stijl. Dit is gedaan voor schoolverlaters van het HAVO die doorstromen naar het HBO, schoolverlaters van het VWO die doorstromen naar het $\mathrm{HBO}$ en schoolverlaters van het VWO die doorstromen naar het WO.

De resultaten laten zien dat volgens HAVO- en VWO-schoolverlaters de aansluiting tussen de gevolgde opleiding en de vervolgopleiding is verbeterd na de invoering van de tweede fase. Dit blijkt uit het feit dat de huidige generatie schoolverlaters de aansluiting tussen de gevolgde opleiding en de vervolgopleiding vaker goed vinden dan de oudere generaties schoolverlaters. Met name havisten nieuwe stijl zijn nu vaker tevreden over de aansluiting dan voorheen. Daarnaast is naar voren gekomen dat HAVO/VWO-schoolverlaters de begeleiding in het eerste jaar van de vervolgopleiding na de invoering van de tweede fase vaker goed vinden dan ervoor. Verder geldt dat HAVO- en VWO-schoolverlaters nu vaker zeggen achteraf gezien voor dezelfde vervolgopleiding aan dezelfde instelling te kiezen dan voorheen.

Aan HAVO/VWO-schoolverlaters is een lijst met algemene vaardigheden voorgelegd die in 12 categorieën zijn onderscheiden; zelfstandig werken, creativiteit, initiatief, communicatieve vaardigheden, samenwerken, studieplanning, informatie verzamelen en verwerken, taalvaardigheid, rekenvaardigheden, computervaardig-heden, nauwkeurig werken en analytische vaardigheden. Schoolverlaters oude en nieuwe stijl zeggen deze vaardigheden in vrijwel gelijke mate nodig te hebben in de vervolgopleiding. Bovendien verschillen de oude en nieuwe stijl schoolverlaters niet in de mate waarin ze aangeven deze vaardigheden te beheersen.

Wel lijkt het erop dat sinds de introductie van het studiehuis er een verschuiving heeft plaatsgevonden van de plaats waar vaardigheden worden geleerd. Schoolverlaters geven nu vaker dan voorheen aan dat ze zelfstandig werken hebben geleerd in het voortgezet onderwijs. Hetzelfde zien we bij samenwerken. Waarschijnlijk speelt hierbij mee dat sinds de invoering van de tweede fase de nadruk minder ligt op klassikaal onderwijs en meer op vaardigheidsonderwijs. Daarnaast is naar voren gekomen dat HAVO/VWO-schoolverlaters na de invoering van de tweede fase minder vaak zeggen dat in het voortgezet onderwijs meer aandacht moet worden besteed aan zelfstandig werken. Het bovenstaande geeft aan dat naar eigen inschatting de zelfstandigheid van schoolverlaters is toegenomen.

Het aandeel HAVO/VWO-schoolverlaters dat zegt de vervolgopleiding voortijdig te hebben verlaten is na de invoering van de tweede fase iets afgenomen. We zien dat dit aandeel vooral vanaf 2003 is afgenomen. De belangrijkste redenen die 
schoolverlaters noemen om de vervolgopleiding voortijdig te verlaten zijn: 'achteraf gezien liever een andere opleiding volgen' en 'onvoldoende motivatie'. Daarbij geldt dat HAVO- en VWO-schoolverlaters de reden 'onvoldoende motivatie' nu minder vaak noemen dan vroeger. Hetzelfde zien we bij redenen 'de lessen waren niet interessant' en 'de opleiding was te moeilijk'.

Verder blijkt dat met name havisten sinds de invoering van de tweede fase vaker tevreden zijn over de hulp bij het vakkenpakket/profiel. Bovendien zeggen schoolverlaters nu vaker dan vroeger dat ze achteraf gezien voor hetzelfde vakkenpakket/profiel zouden kiezen. Ook hier geldt dit vooral voor havisten die doorstromen naar het HBO. De belangrijkste reden voor schoolverlaters nieuwe stijl om niet opnieuw te kiezen voor het gevolgde profiel is dat deze onvoldoende aansluit bij de vervolgopleiding.

Verder komt naar voren dat schoolverlaters nu wat minder positief zijn in hun oordeel over de hulp bij studie- of beroepskeuze dan voorheen. Zowel bij havisten die doorgaan naar het HBO als bij VWO'ers die doorstromen naar het HBO en WO is het aandeel schoolverlaters nieuwe stijl dat (zeer) tevreden is over de hulp bij de keuze van een vervolgopleiding of een beroep lager dan bij schoolverlaters oude stijl.

Geconcludeerd kan worden dat op de meeste terreinen HAVO- en VWOschoolverlaters nieuwe stijl positiever zijn in hun oordeel over de aansluiting tussen het voortgezet en hoger onderwijs dan HAVO- en VWO-schoolverlaters oude stijl. Ook lijkt de uitval in de vervolgopleiding iets te zijn afgenomen. Dit wijst in de richting van een verbeterde aansluiting tussen $\mathrm{VO}$ en $\mathrm{HO}$ als gevolg van de invoering van de tweede fase. 


\section{Inleiding}

In augustus 1998 is in het HAVO en VWO de tweede fase ingevoerd. Concreet betekende dit dat in augustus 1998125 scholen voor het HAVO en VWO zijn gestart met de tweede fase. De overige 430 scholen voor HAVO en VWO deden dat in augustus 1999 .

De doelstelling van de tweede fase in het voortgezet onderwijs is drieledig: 1) de aansluiting tussen het HAVO en VWO op het hoger onderwijs verbeteren, 2) het onderwijsprogramma in de hogere leerjaren moderniseren en leerlingen in beter herkenbare en meer samenhangende programma's gerichter voorbereiden op bepaalde opleidingen in het hoger onderwijs en 3) scholen meer ruimte geven in de keuze van werkvormen in het onderwijsprogramma voor de hoger leerjaren. De tweede fase van het VO is ingericht als een studiehuis. In dit studiehuis worden scholieren geleerd actief en zelfstandig kennis en vaardigheden tot zich te nemen ('leren leren'). Bovendien is het tot dan toe bestaande systeem van vakkenpakketkeuze in de hogere leerjaren vervangen door vier studieprofielen in te voeren; cultuur en maatschappij, economie en maatschappij, natuur en gezondheid en natuur en techniek.

Het Ministerie van OCenW heeft besloten de invoering van de tweede fase VO uitgebreid te monitoren en te evalueren. In dit kader heeft het Tweede Fase Adviespunt aan het Researchcentrum voor Onderwijs en Arbeidsmarkt (ROA) gevraagd om een deelonderzoek uit te voeren onder schoolverlaters van het HAVO en VWO. Centraal in dit onderzoek staat de vraag hoe HAVO- en VWOschoolverlaters de aansluiting tussen het voortgezet en hoger onderwijs voor en na de invoering van de tweede fase ervaren. Hiervoor zijn de antwoorden van gediplomeerde schoolverlaters van het HAVO/VWO oude stijl (d.w.z. voor de invoering van de tweede fase) vergeleken met die van gediplomeerde schoolverlaters van het HAVO/VWO nieuwe stijl. Daarbij maken we een onderscheid tussen drie groepen schoolverlaters, namelijk; schoolverlaters van het HAVO die doorstromen naar het $\mathrm{HBO}$, schoolverlaters van het VWO die doorstromen naar het $\mathrm{HBO}$ en schoolverlaters van het VWO die doorstromen naar het WO.

\section{Gegevens}

Voor dit rapport is gebruik gemaakt van gegevens uit het schoolverlatersonderzoek Registratie van Uitstroom en Bestemming van Schoolverlaters (RUBS). Dit is een grootschalig onderzoek dat het ROA jaarlijks uitvoert onder schoolverlaters van het algemeen voortgezet onderwijs (MAVO, HAVO, VWO), het voorbereidend beroepsonderwijs (VBO) en de beroepsopleidende (BOL) en beroepsbegeleidende (BBL) leerwegen van het secundair beroepsonderwijs. De schoolverlaters worden ongeveer anderhalf jaar na het verlaten van de opleiding ondervraagd middels een schriftelijke vragenlijst. Deze vragenlijst bestaat uit een gedeelte dat voor elke onderwijssoort identiek is en uit een variabel gedeelte waarbij de inhoud afhankelijk 
is van de onderwijssoort en/of de opleidingssector. Voor schoolverlaters van HAVO en VWO ligt het accent op de doorstroom naar vervolgonderwijs, waarbij vooral de aansluiting met het hoger onderwijs aan bod komt.

Zoals gezegd worden gediplomeerde schoolverlaters van het HAVO/VWO oude stijl vergeleken met gediplomeerde schoolverlaters van het HAVO/VWO nieuwe stijl. De gegevens van schoolverlaters van het HAVO/VWO oude stijl zijn afkomstig van de RUBS-enquête, metingen 2000, 2001 en 2002. Deze hebben betrekking op schoolverlaters die in het schooljaar 1998/1999, 1999/2000 en 2000/2001 het HAVO/VWO-diploma hebben behaald. De gegevens van schoolverlaters van het HAVO/NWO nieuwe stijl zijn afkomstig de RUBS-enquête, metingen 2002, 2003 en 2004. Deze hebben betrekking op schoolverlaters die in het schooljaar 2000/2001, 2001/2002 en 2002/2003 de HAVO/VWO-opleiding hebben afgerond.

De dekkingsgraad van de RUBS-enquête varieert enigszins tussen de jaren, maar bedraagt gemiddeld genomen ongeveer 6\% van alle HAVO/VWO onderwijsinstellingen in de meetjaren 2000, 2001 en 2002. De dekkingsgraad in de meetjaren 2003 en 2004 bedraagt zo'n 12\% van alle HAVO/VWO onderwijsinstellingen. De steekproef kan worden beschouwd als representatief voor alle HAVO- en VWOschoolverlaters in Nederland die in de betreffende schooljaren het diploma hebben behaald.

Tabel 1.1

Aantal gediplomeerde HAVO/VWO-schoolverlaters oude en nieuwe stijl, naar vervolgopleiding in het hoger onderwijs

HAVO oude stijl - HBO

VWO oude stijl - HBO

2.193

VWO oude stijl - WO

712

totaal

HAVO nieuwe stijl - HBO

VWO nieuwe stijl - HBO

Totaal

6.751

Tabel 1.1 geeft een overzicht van het aantal schoolverlaters van het HAVO en VWO dat is opgenomen in de analyses van dit rapport. Hierbij is een uitsplitsing gemaakt naar oude en nieuwe stijl. Bovendien is het niveau van de vervolgopleiding in het hoger onderwijs van de HAVO- en VWO-schoolverlaters weergegeven. Het betreft hier de ongewogen aantallen. In de kruistabellen van dit rapport is gebruik gemaakt van de gewogen aantallen. De weging is uitgevoerd om betrouwbare landelijke gegevens te kunnen presenteren. Bij de weging wordt rekening gehouden met opleiding, geslacht en regio. De weging wordt zodanig uitgevoerd dat de aantallen uiteindelijk corresponderen met de aantallen in de populatie. Voor de weging wordt 
gebruik gemaakt van populatiegegevens die beschikbaar zijn op basis van de Integrale Leerlingtellingen (Huijgen, 2004). ${ }^{1}$

\section{Opzet van het rapport}

Dit rapport is als volgt opgebouwd. Hoofdstuk 2 gaat in op de doorstroom naar een vervolgopleiding in het hoger onderwijs. Daarnaast wordt in dit hoofdstuk nog gekeken naar andere kenmerken van schoolverlaters van het HAVO en VWO, zoals het gevolgde profiel. Centraal in hoofdstuk 3 staat de aansluiting tussen gevolgde opleiding en vervolgopleiding in het hoger onderwijs. Voor HAVO/VWOschoolverlaters oude en nieuwe stijl wordt bekeken in hoeverre ze tevreden zijn over deze aansluiting. Bovendien wordt onderzocht of schoolverlaters tevreden zijn over de begeleiding in het eerste jaar van de vervolgopleiding. In hoofdstuk 4 komen algemene vaardigheden van schoolverlaters aan bod. Aan schoolverlaters is gevraagd in hoeverre ze deze vaardigheden nodig hebben in de vervolgopleiding, in welke mate ze de vaardigheden beheersen, en waar ze de vaardigheden hebben geleerd. Bovendien wordt onderzocht of schoolverlaters vinden dat deze vaardigheden voldoende aan bod zijn gekomen in de HAVO/VWO-opleiding. In het vijfde hoofdstuk van dit rapport wordt stilgestaan bij de vraag of schoolverlaters achteraf gezien dezelfde vervolgopleiding zouden kiezen. Besproken wordt in welke mate schoolverlaters aangeven achteraf bezien voor dezelfde vervolgopleiding te kiezen, en zo ja of dit een vervolgopleiding aan dezelfde instelling of een andere instelling betreft. Hoofdstuk 6 bespreekt de uitval in de vervolgopleiding. Hiervoor wordt eerst gekeken naar het aandeel schoolverlaters dat aangeeft de vervolgopleiding nog steeds te volgen of voortijdig te hebben verlaten. Daarna wordt ingegaan op de redenen die schoolverlaters geven om de vervolgopleiding voortijdig te verlaten. Ook wordt bekeken of de uitvallers opnieuw een opleiding zijn gaan volgen of hebben gekozen voor de arbeidsmarkt. In hoofdstuk 7 wordt voor HAVOen VWO-schoolverlaters de keuze voor het gevolgde vakkenpakket/profiel geëvalueerd. Bekeken wordt in hoeverre schoolverlaters tevreden zijn over de hulp bij de keuze van het vakkenpakket/profiel, en of ze achteraf gezien opnieuw voor hetzelfde vakkenpakket/profiel zouden kiezen. Ook de redenen om niet opnieuw voor het gevolgde vakkenpakket/profiel te kiezen wordt besproken in dit hoofdstuk. In het slothoofdstuk staat de hulp bij de studie- en beroepskeuze in het voortgezet onderwijs centraal. Ingegaan wordt op de informatie die schoolverlaters hebben ontvangen over de studie- en beroepskeuze. Eerst wordt besproken welke informatie schoolverlaters hebben ontvangen, en daarbij wordt bekeken in hoeverre schoolverlaters tevreden zijn over de kwaliteit van deze informatie. Vervolgens wordt ingegaan op de vraag welke informatiebronnen schoolverlaters hebben gebruikt en welke daarbij het nuttigst is geweest.

1. T. Huijgen (2004), Methodiek Schoolverlatersinformatiesysteem 2003, ROA-W-2004/3, Maastricht. 



\section{Doorstroom naar het hoger onderwijs}

In dit hoofdstuk wordt de bestemming van gediplomeerde HAVO/VWO-schoolverlaters bekeken voor en na de invoering van de tweede fase. Ingegaan wordt op de vraag voor welke vervolgopleiding schoolverlaters kiezen, en welk deel niet verder gaat studeren en kiest voor een andere bestemming. Daarna komt een aantal achtergrondkenmerken van de HAVO/VWO-schoolverlaters aan bod, zoals het gevolgde profiel.

Tabel 2.1 laat de bestemming zien van HAVO en VWO-schoolverlaters. In deze tabel is vermeld welk type vervolgopleiding schoolverlaters hebben gekozen en bovendien is aangegeven welk deel van de schoolverlaters aangeeft te hebben gekozen voor een combinatie van werken en leren of een betaalde baan. Uit deze tabel blijkt dat schoolverlaters van het HAVO na de invoering van de tweede fase vaker aangeven dat ze hebben gekozen voor het HBO. Waar voor de invoering van de tweede fase $77 \%$ van de havisten aangeeft verder te gaan in het $\mathrm{HBO}$, zegt nu $85 \%$ te hebben gekozen voor een vervolgopleiding in het $\mathrm{HBO}$. Bij het WO zien we dat voorheen $66 \%$ van de schoolverlaters verder studeerde in het $W O$, en nu zegt $75 \%$ dit. Daarnaast blijkt uit tabel 2.1 dat havisten en VWO'ers nu minder vaak dan voorheen aangeven te hebben gekozen voor betaald werk.

Overigens laten cijfers van het Centraal Bureau voor de Statistiek (CBS) zien dat het aandeel HAVO/VWO-schoolverlaters dat doorstroomt naar het hoger onderwijs de afgelopen tien jaar vrij geleidelijk is toegenomen. Er lijkt dus eerder sprake te zijn van een trendmatige ontwikkeling, waarbij steeds meer gediplomeerden van het HAVO en VWO doorstromen naar het hoger onderwijs, dan van een trendbreuk na de invoering van de tweede fase.

Tabel 2.1

Bestemming van HAVO/NWO-schoolverlaters oude en nieuwe stijl

\begin{tabular}{|c|c|c|c|c|c|c|c|}
\hline & VWO & MBO & $\mathrm{HBO}$ & WO & $\begin{array}{l}\text { Werkend } \\
\text { leren }\end{array}$ & $\begin{array}{c}\text { Betaald } \\
\text { werk }\end{array}$ & Overig \\
\hline \multicolumn{8}{|c|}{ Oude stijl } \\
\hline HAVO & 2 & 10 & 77 & 0 & 1 & 5 & 4 \\
\hline VWO & 0 & 0 & 30 & 66 & 0 & 2 & 2 \\
\hline \multicolumn{8}{|c|}{ Nieuwe stijl } \\
\hline HAVO & 1 & 5 & 85 & 1 & 2 & 3 & 3 \\
\hline VWO & 0 & 0 & 21 & 75 & 0 & 1 & 2 \\
\hline
\end{tabular}

Tabel 2.2 vermeldt het profiel dat HAVO/VWO-schoolverlaters hebben gevolgd. Het blijkt dat het merendeel van de havisten het profiel cultuur en maatschappij en economie en maatschappij hebben gevolgd. Daarbij geldt dat bij het HAVO vrouwen duidelijk vaker kiezen voor het profiel cultuur en maatschappij. Mannen vinden we daarentegen vaker terug in de profielen economie en maatschappij en natuur en 
techniek. Verder kiezen in het HAVO mannen en vrouwen bijna even vaak voor natuur en gezondheidszorg.

Door schoolverlaters van het VWO zijn de profielen economie en maatschappij en natuur en gezondheid het vaakst gekozen. Ook bij het VWO bestaan duidelijke verschillen tussen mannen en vrouwen. Mannen kiezen vaker voor economie en maatschappij én mannen zijn duidelijk oververtegenwoordigd in het profiel natuur en techniek. Vrouwen kiezen daarentegen vaker voor de profielen cultuur en maatschappij en natuur en gezondheid. De cijfers in tabel 2.2 zijn vergelijkbaar met cijfers van het CBS over het gevolgde profiel van gediplomeerde HAVO- en VWOschoolverlaters.

Verder blijkt dat maar weinig havisten en VWO'ers van profiel wisselen tijdens de opleiding. In totaal $5 \%$ van de HAVO-schoolverlaters en $6 \%$ van de VWOschoolverlaters zegt van profiel te zijn gewisseld (hier niet vermeld in tabelvorm).

Tabel 2.2

Gevolgde profiel HAVO/VWO-schoolverlaters nieuwe stijl, naar geslacht

\begin{tabular}{lrccr}
\hline & $\begin{array}{c}\text { cultuur en } \\
\text { maatschappij }\end{array}$ & $\begin{array}{c}\text { economie en } \\
\text { maatschappij }\end{array}$ & $\begin{array}{c}\text { natuur en } \\
\text { gezondheid }\end{array}$ & $\begin{array}{c}\text { natuur en } \\
\text { techniek }\end{array}$ \\
\hline HAVO & & & & \\
$\quad$ Totaal & 33 & 40 & 15 & 12 \\
Man & 9 & 54 & 13 & 25 \\
$\quad$ Vrouw & 52 & 29 & 17 & 2 \\
VWO & 20 & 34 & 28 & 18 \\
$\quad$ Totaal & 5 & 39 & 21 & 35 \\
Man & 32 & 29 & 34 & 5 \\
Vrouw & & & & \\
\hline
\end{tabular}




\section{Aansluiting tussen gevolgde opleiding en vervolgopleiding}

In dit hoofdstuk staat de aansluiting tussen de HAVO/VWO-opleiding en de opleiding in het hoger onderwijs centraal. Eerst wordt bekeken hoe schoolverlaters van het HAVO en VWO de aansluiting tussen de gevolgde opleiding en de vervolgopleiding hebben ervaren voor en na de invoering van de tweede fase. Vervolgens wordt ingegaan op de vraag in hoeverre HAVO/VWO-schoolverlaters tevreden zijn over de begeleiding in het eerste jaar van de vervolgopleiding.

\section{Aansluiting HAVONWO en het hoger onderwijs}

Aan schoolverlaters van HAVO en VWO is gevraagd hoe ze de aansluiting tussen de gevolgde HAVO/VWO-opleiding en de vervolgopleiding hebben ervaren; goed, redelijk, matig of slecht. In tabel 3.1 zijn de resultaten hiervan weergegeven voor schoolverlaters oude en nieuwe stijl. Voor de invoering van de tweede fase vond $24 \%$ van de HAVO-schoolverlaters de aansluiting tussen het HAVO en het HBO goed, $43 \%$ vond deze aansluiting redelijk, $25 \%$ matig en $7 \%$ slecht. Interessant is dat schoolverlaters van het HAVO na de invoering van de tweede fase duidelijk vaker aangeven de aansluiting met het $\mathrm{HBO}$ als goed te ervaren. In totaal vindt $38 \%$ van de havisten nieuwe stijl de aansluiting met het $\mathrm{HBO}$ goed. Bovendien is het aandeel schoolverlaters van het HAVO dat redelijk tevreden is over de aansluiting met het HBO nu iets hoger dan voorheen.

Tabel 3.1

Aandeel HAVO/VWO-schoolverlaters oude en nieuwe stijl dat de aansluiting tussen de gevolgde opleiding en vervolgopleiding goed, redelijk, matig of slecht vindt

\begin{tabular}{lcccc}
\hline & goed & redelijk & matig & slecht \\
\hline HAVO oude stijl - HBO & 24 & 43 & 25 & 7 \\
VWO oude stijl - HBO & 47 & 39 & 10 & 3 \\
VWO oude stijl - WO & 39 & 45 & 14 & 2 \\
& & & & \\
HAVO nieuwe stijl - HBO & 38 & 46 & 13 & 3 \\
VWO nieuwe stijl - HBO & 54 & 35 & 9 & 3 \\
VWO nieuwe stijl - WO & 44 & 40 & 13 & \\
\hline
\end{tabular}

Tabel 3.1 laat zien dat bij het VWO het aandeel schoolverlaters dat de aansluiting met de vervolgopleiding in het hoger onderwijs goed vindt ook is toegenomen na de invoering van de tweede fase. Deze toename is echter minder groot dan voor schoolverlaters van het HAVO. Waarschijnlijk heeft dit te maken met het feit dat in vergelijking met het HAVO relatief veel schoolverlaters van het VWO oude stijl de aansluiting met het hoger onderwijs al redelijk tot goed vonden. Uit tabel $3.1 \mathrm{komt}$ naar voren dat voorheen $47 \%$ van de VWO'ers de aansluiting met het HBO goed 
vindt, terwijl dit na de invoering van de tweede fase $54 \%$ is. Voor VWO'ers die doorstromen naar het WO geldt dat voorheen $39 \%$ de aansluiting met het WO goed vond, en nu is dit $44 \%$. Daarentegen is het aandeel schoolverlaters van het VWO dat de aansluiting met een opleiding in het hoger onderwijs redelijk vindt na de invoering van de tweede fase iets gedaald. Het aandeel VWO'ers dat deze aansluiting matig of slecht vindt, is vrijwel gelijk voor VWO-schoolverlaters oude en nieuwe stijl.

Al met al kan worden geconcludeerd dat volgens schoolverlaters van het HAVO en het VWO de aansluiting tussen de gevolgde opleiding en vervolgopleiding in het hoger onderwijs is verbeterd na de invoering van de tweede fase. Dit geldt met name voor schoolverlaters van het HAVO. Belangrijk is te vermelden dat er duidelijk sprake is van een trendbreuk na de invoering van de tweede fase, en niet van een trendmatige ontwikkeling. Dit blijkt wanneer we elk meetjaar afzonderlijk bekijken (in onze tabellen worden zoals in de inleiding is vermeld meerdere meetjaren samengenomen). Vóór de invoering van de tweede fase vinden we voor elk meetjaar een percentage van ongeveer $24 \%$ van de havisten dat zegt de aansluiting met de vervolgopleiding goed te vinden (zie figuur 3.1). Ná de invoering van de tweede fase is dit percentage voor ieder meetjaar ongeveer $38 \%$. Een zelfde trendbreuk vinden we na de invoering van de tweede fase bij VWO'ers die verder gaan in het WO, en in zekere zin ook bij VWO'ers die doorstromen naar het HBO.

Figuur 3.1

Aandeel HAVO/VWO-schoolverlaters oude en nieuwe stijl dat de aansluiting tussen de gevolgde opleiding en vervolgopleiding goed vindt per meetjaar

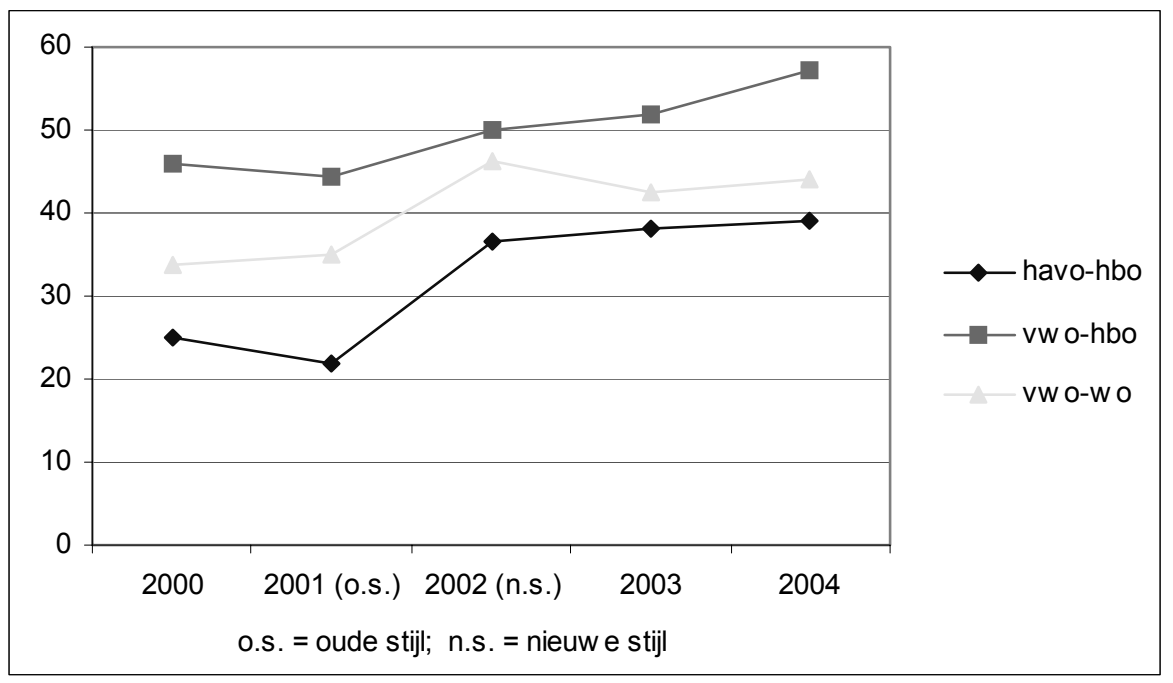

Tabel 3.2 vermeldt de aansluiting tussen de gevolgde opleiding en vervolgopleiding voor schoolverlaters van het HAVO en VWO naar profiel. Voor schoolverlaters van het HAVO die doorstromen naar het HBO geldt dat degenen die het profiel cultuur en maatschappij hebben gevolgd duidelijk het vaakst aangeven dat de aansluiting met de vervolgopleiding goed is. Schoolverlaters van het HAVO met een ander profiel 
dan cultuur en maatschappij zeggen relatief vaak dat de aansluiting met de vervolgopleiding in het $\mathrm{HBO}$ redelijk is. Bij schoolverlaters van het VWO die verder studeren in het $\mathrm{HBO}$ zijn wat dit betreft vrij weinig verschillen te zien naar profiel. Van de VWO'ers die verder studeren in het WO geven degenen die cultuur en maatschappij of natuur en gezondheid hebben gevolgd het vaakst aan dat de aansluiting met de vervolgopleiding goed is.

Tabel 3.2

Aandeel HAVO/VWO-schoolverlaters dat de aansluiting tussen de gevolgde opleiding en vervolgopleiding goed, redelijk, matig of slecht vindt, naar profiel

\begin{tabular}{|c|c|c|c|c|}
\hline & goed & redelijk & matig & slecht \\
\hline \multicolumn{5}{|l|}{ HAVO nieuwe stijl - HBO } \\
\hline cultuur en maatschappij & 47 & 41 & 11 & 2 \\
\hline economie en maatschappij & 34 & 50 & 12 & 4 \\
\hline natuur en gezondheid & 34 & 48 & 16 & 3 \\
\hline natuur en techniek & 32 & 44 & 18 & 7 \\
\hline \multicolumn{5}{|l|}{ VWO nieuwe stijl - HBO } \\
\hline cultuur en maatschappij & 55 & 39 & 4 & 2 \\
\hline economie en maatschappij & 55 & 32 & 11 & 2 \\
\hline natuur en gezondheid & 53 & 37 & 9 & 1 \\
\hline natuur en techniek & 49 & 34 & 14 & 2 \\
\hline \multicolumn{5}{|l|}{ VWO nieuwe stijl - WO } \\
\hline cultuur en maatschappij & 48 & 41 & 9 & 2 \\
\hline economie en maatschappij & 37 & 44 & 16 & 3 \\
\hline natuur en gezondheid & 53 & 36 & 8 & 2 \\
\hline natuur en techniek & 39 & 41 & 17 & 3 \\
\hline
\end{tabular}

De aansluiting tussen de gevolgde opleiding en de vervolgopleiding is vervolgens multivariaat geanalyseerd. Aan de hand van een multivariate analyse kan de zelfstandige invloed van verschillende kenmerken van schoolverlaters tegelijkertijd in één analyse worden onderzocht. We hebben hier de kans dat schoolverlaters van het HAVO/VWO de aansluiting met de vervolgopleiding goed vinden geanalyseerd. In deze multivariate analyse zijn de volgende kenmerken meegenomen; sekse, het gevolgde profiel, profieloverstap, het gemiddeld examencijfer, de hoogst behaalde vooropleiding, de duur van de HAVO/VWO-opleiding en de sector van de vervolgopleiding. Voorwaarde voor zo'n analyse is dat de kenmerken die worden opgenomen onderling niet heel sterk met elkaar zijn gecorreleerd. Dit blijkt in onze analyse niet het geval te zijn. In tabel 3.3 zijn de resultaten van de multivariate analyse weergegeven. Vermeld is of een bepaald kenmerk een negatief significant effect, positief significant effect of geen significant effect heeft op de kans dat schoolverlaters de aansluiting met de vervolgopleiding goed vinden.

Tabel 3.3 laat eerst de resultaten zien voor havisten die verder gaan in het HBO. Hieruit blijkt allereerst dat geslacht een significante invloed heeft op de kans dat havisten de aansluiting met een opleiding in het HBO goed vinden. Mannen vinden significant minder vaak dan vrouwen dat deze aansluiting goed is. Daarnaast laat het 
behaalde examencijfer hier een significant positief effect zien. Dit betekent dat havisten de aansluiting met de vervolgopleiding vaker goed vinden naarmate ze een hoger eindexamencijfer hebben behaald. Verder geldt dat vooral havisten die kiezen voor een vervolgopleiding in de sector onderwijs de aansluiting met de vervolgopleiding goed vinden.

Tabel 3.3

Multivariate analyse van de kans dat HAVO/NWO-schoolverlaters de aansluiting met de vervolgopleiding goed vinden

\begin{tabular}{|c|c|c|c|}
\hline & $\begin{array}{l}\text { HAVO nieuwe } \\
\text { stijl - HBO }\end{array}$ & $\begin{array}{l}\text { VWO nieuwe } \\
\text { stijl - HBO }\end{array}$ & $\begin{array}{l}\text { VWO nieuwe } \\
\text { stijl - WO }\end{array}$ \\
\hline \multicolumn{4}{|l|}{ Geslacht } \\
\hline vrouw & referentie & referentie & referentie \\
\hline man & - & 0 & - \\
\hline \multicolumn{4}{|l|}{ Profiel } \\
\hline cultuur en maatschappij & 0 & 0 & 0 \\
\hline economie en maatschappij & referentie & referentie & referentie \\
\hline natuur en gezondheid & 0 & - & + \\
\hline natuur en techniek & 0 & 0 & + \\
\hline Profieloverstap & 0 & 0 & 0 \\
\hline Gemiddeld examencijfer & + & 0 & + \\
\hline \multicolumn{4}{|l|}{ Hoogst behaalde vooropleiding } \\
\hline geen & referentie & referentie & referentie \\
\hline mavo & 0 & \# & \# \\
\hline havo & \# & 0 & 0 \\
\hline anders & 0 & 0 & 0 \\
\hline Duur havo/vwo opleiding & 0 & 0 & 0 \\
\hline \multicolumn{4}{|l|}{ Sector vervolgopleiding } \\
\hline landbouw & 0 & 0 & + \\
\hline onderwijs & + & 0 & \# \\
\hline techniek & 0 & 0 & 0 \\
\hline economie & referentie & referentie & referentie \\
\hline gezondheidszorg & 0 & + & + \\
\hline gedrag en maatschappij & 0 & 0 & + \\
\hline taal en cultuur & 0 & 0 & + \\
\hline recht en openbare orde & \# & \# & 0 \\
\hline natuurwetenschappen & \# & \# & 0 \\
\hline
\end{tabular}

- = negatief significant effect op 5\%-niveau

$0=$ geen significant effect op $5 \%$-niveau

$+=$ positief significant effect op $5 \%$-niveau

$\#=$ komt niet voor

Vervolgens zijn in tabel 3.3 de resultaten van de multivariate analyse weergegeven voor schoolverlaters van het VWO die verder gaan in het HBO. Van de VWO'ers die verder studeren in het $\mathrm{HBO}$ vinden schoolverlaters met het profiel natuur en gezondheid het minst vaak de aansluiting met de vervolgopleiding goed. Daarnaast blijkt dat VWO'ers die kiezen voor een HBO-opleiding in de sector gezondheidszorg vaker de aansluiting met de vervolgopleiding goed vinden dan VWO'ers die kiezen voor een vervolgopleiding in een andere sector van het $\mathrm{HBO}$. 
Tabel 3.3 laat verder zien dat verschillende kenmerken van schoolverlaters van het VWO die doorstromen naar het WO van invloed zijn op de kans dat deze de aansluiting met de vervolgopleiding goed vinden. Ten eerste blijkt dat mannen minder vaak dan vrouwen de aansluiting tussen het VWO en de vervolgopleiding in het WO goed vinden. Ten tweede vinden VWO'ers met het profiel natuur en gezondheid of natuur en techniek de aansluiting met de opleiding in het WO vaker goed dan VWO'ers met het profiel economie en maatschappij. Ten derde vinden VWO'ers de aansluiting met de vervolgopleiding in het WO vaker goed als ze een hoger eindexamencijfer hebben behaald. Ten vierde geldt dat met name VWO'ers die kiezen voor een vervolgopleiding in de sectoren WO landbouw, WO gezondheidszorg, WO gedrag en maatschappij en WO taal en cultuur de aansluiting met de vervolgopleiding goed vinden.

\section{Begeleiding in het eerste jaar van de vervolgopleiding}

In tabel 3.4 is het aandeel schoolverlaters van het HAVO en VWO vermeld dat de begeleiding in het eerste jaar van de vervolgopleiding goed, redelijk, matig of slecht vindt.

Tabel 3.4

Aandeel HAVO/VWO-schoolverlaters oude en nieuwe stijl dat de begeleiding in het eerste jaar van de vervolgopleiding goed, redelijk, matig of slecht vindt

\begin{tabular}{lcccc}
\hline & goed & redelijk & matig & slecht \\
\hline HAVO oude stijl - HBO & 29 & 42 & 21 & 9 \\
VWO oude stijl - HBO & 37 & 39 & 18 & 6 \\
VWO oude stijl - WO & 28 & 45 & 19 & 8 \\
& & & & 5 \\
HAVO nieuwe stijl - HBO & 33 & 44 & 18 & 4 \\
VWO nieuwe stijl - HBO & 44 & 40 & 12 & 5 \\
VWO nieuwe stijl - WO & 33 & 43 & 19 & \\
\hline
\end{tabular}

Tabel 3.4 laat zien dat HAVO/VWO-schoolverlaters na de invoering van de tweede fase iets vaker tevreden zijn over de begeleiding in het eerste jaar dan voor de invoering. Voor de begeleiding in het eerste jaar van de vervolgopleiding geldt dus ook dat HAVO/VWO-schoolverlaters nieuwe stijl meer tevreden zijn dan HAVO/VWO-schoolverlaters oude stijl. De verschillen zijn hier echter niet bijzonder groot. Van de havisten zegt nu 33\% dat de begeleiding in het eerste jaar van de HBO-vervolgopleiding goed is, tegen $29 \%$ voorheen. Van de VWO'ers die doorstromen naar het $\mathrm{HBO}$ vindt $44 \%$ van de schoolverlaters oude stijl en $37 \%$ van de schoolverlaters oude stijl de begeleiding in het eerste jaar goed. Voor schoolverlaters van het VWO die doorstromen naar het WO bedraagt dit aandeel nu $33 \%$ en eerder $28 \%$. Verder valt ook hier op dat vooral schoolverlaters van het VWO die verder gaan studeren in het HBO de begeleiding in het eerste jaar het vaakst goed vinden. 
In tabel 3.5 is de mate waarin schoolverlaters tevreden zijn over de begeleiding in het eerste jaar van de vervolgopleiding uitgesplitst naar profiel. Voor havisten die doorstromen naar het HBO geldt dat schoolverlaters met het profiel cultuur en maatschappij en natuur en gezondheid de begeleiding in het eerste jaar vaker goed vinden dan havisten die het profiel economie en maatschappij en natuur en techniek hebben gevolgd. Van de VWO'ers vinden vooral degenen die het profiel natuur en gezondheid of het profiel natuur en techniek hebben gevolgd de begeleiding in het eerste jaar van de vervolgopleiding goed. Dit geldt zowel voor VWO'ers die verder gaan studeren in het HBO als voor VWO'ers die doorstromen naar het WO.

Tabel 3.5

Aandeel HAVO/VWO-schoolverlaters dat de begeleiding in het eerste jaar van de vervolgopleiding goed, redelijk, matig of slecht vindt, naar profiel

\begin{tabular}{lllll}
\hline & goed & redelijk & matig & slecht \\
\hline HAVO nieuwe stijl - HBO & & & & \\
cultuur en maatschappij & 37 & 43 & 16 & 4 \\
economie en maatschappij & 32 & 43 & 19 & 6 \\
natuur en gezondheid & 37 & 46 & 13 & 4 \\
natuur en techniek & 27 & 42 & 23 & 8 \\
vwo nieuwe stijl - HBO & & & & \\
cultuur en maatschappij & 43 & 36 & 16 & 6 \\
economie en maatschappij & 38 & 45 & 12 & 5 \\
natuur en gezondheid & 51 & 38 & 8 & 3 \\
natuur en techniek & 52 & 37 & 9 & 2 \\
vwo nieuwe stijl - wo & & & & \\
cultuur en maatschappij & 28 & 46 & 20 & 7 \\
economie en maatschappij & 26 & 42 & 24 & 8 \\
natuur en gezondheid & 40 & 41 & 16 & 2 \\
natuur en techniek & 37 & 43 & 15 & 4 \\
& & & & \\
\hline
\end{tabular}

De mate waarin schoolverlaters tevreden zijn over de begeleiding in het eerste jaar van de vervolgopleiding is ook multivariaat geanalyseerd. Het betreft hier de kans dat schoolverlaters de begeleiding in het eerste jaar van de vervolgopleiding goed vinden. In deze analyse zijn dezelfde kenmerken opgenomen als bij de kans dat schoolverlaters de aansluiting tussen gevolgde opleiding en vervolgopleiding goed vinden. Tabel 3.6 vermeldt de resultaten van deze analyse. Dit is eerst weergegeven voor havisten die verder gaan in het HBO. Hieruit komt naar voren dat vrouwen significant vaker dan mannen de begeleiding in eerste jaar van de opleiding in het HBO goed vinden. Daarnaast speelt de vooropleiding van havisten een rol. Naar voren komt dat leerlingen die voorafgaand aan het HAVO het MAVO hebben gevolgd de begeleiding in het eerste jaar van het HBO minder vaak goed vinden dan leerlingen die via het basisonderwijs zijn ingestroomd in het HAVO.

Ook voor VWO'ers die doorstromen naar het HBO geldt dat vrouwen vaker dan mannen de begeleiding in eerste jaar van de opleiding in het HBO goed vinden. Bij 
VWO'ers die verder gaan studeren in het WO laten de overige kenmerken geen significante effecten zien.

Bij VWO'ers die doorstromen naar het WO laten het gevolgde profiel, het gemiddeld examencijfer en de sector van de vervolgopleiding significante effecten zien. Het blijkt dat VWO'ers met het profiel natuur en techniek de begeleiding in het eerste jaar van de opleiding in het WO vaker goed vinden dan VWO'ers met een ander profiel. Daarnaast vinden degenen die een hoog examencijfer hebben behaald in het VWO de begeleiding in het eerste jaar van het WO vaker goed dan degenen die een lager cijfer hebben behaald. Bovendien vinden vooral VWO'ers die kiezen voor een vervolgopleiding in de WO-sectoren landbouw, gezondheidszorg, taal en cultuur en natuurwetenschappen de begeleiding in het eerste jaar van de vervolgopleiding goed.

Tabel 3.6

Multivariate analyse van de kans dat HAVO/VWO-schoolverlaters de begeleiding in het eerste jaar van de vervolgopleiding goed vinden

HAVO nieuwe stijl - VWO nieuwe stijl - VWO nieuwe stijl $\mathrm{HBO}$ $\mathrm{HBO}$ WO

Geslacht
vrouw
man
Profiel
cultuur en maatschappij
economie en maatschappij
natuur en gezondheid
natuur en techniek
Profieloverstap
Gemiddeld examencijfer
Hoogst behaalde vooropleiding
geen
mavo
havo
anders
Duur havo/vwo opleiding
Sector vervolgopleiding
landbouw
onderwijs
techniek
economie
gezondheidszorg
gedrag en maatschappij
taal en cultuur
recht en openbare orde
natuurwetenschappen

referentie
-
0
referentie
0
0
0
0

referentie

0 referentie

0

0

0
0

referentie

\#

\#

\section{0}

$+$

referentie

0

0

\# referentie

\#

0

0

0

0

0

referentie

0

0

0

\# referentie

0

0

referentie

0

$+$

0
+

referentie

\#

0

0

0

$+$

\#

referentie

$+$

0

$+$

0

- = negatief significant effect op 5\%-niveau

$0=$ geen significant effect op $5 \%$-niveau

$+=$ positief significant effect op $5 \%$-niveau

\# = komt niet voor 



\section{Algemene vaardigheden}

In dit hoofdstuk wordt ingegaan op de algemene vaardigheden van schoolverlaters van het HAVO en VWO. Aan HAVO/VWO-schoolverlaters is een lijst met algemene vaardigheden voorgelegd die in 12 categorieën zijn onderscheiden; zelfstandig werken, creativiteit, initiatief, communicatieve vaardigheden, samenwerken, studieplanning, informatie verzamelen en verwerken, taalvaardigheid, rekenvaardig-heden, computervaardigheden, nauwkeurig werken en analytische vaardigheden. De schoolverlaters hebben kunnen aangeven 1) in hoeverre ze de vaardigheden nodig hebben in de vervolgopleiding, 2) hoe goed ze de vaardigheden beheersen, 3) waar ze de vaardigheden vooral hebben geleerd en 4) aan welke van de vaardigheden meer aandacht had moeten worden besteed in de opleiding.

\section{Vaardigheden die nodig zijn in de vervolgopleiding}

Aan de schoolverlaters is eerst gevraagd voor iedere vaardigheid aan te geven in hoeverre ze deze nodig hebben in de vervolgopleiding. Dit is gemeten op een vijfpuntschaal die loopt van vrijwel niet tot heel veel. In figuur 4.1 is voor de havisten en VWO'ers oude en nieuwe stijl het aandeel schoolverlaters vermeld dat aangeeft de betreffende vaardigheid (heel) veel nodig te hebben in de vervolgopleiding (antwoordcategorie 4 of 5). Hieruit blijkt dat schoolverlaters van het HAVO die doorstromen naar het HBO voor en na de invoering van de tweede fase vrijwel even vaak zeggen de vaardigheden nodig te hebben in de vervolgopleiding. Nergens is het verschil tussen havisten oude en havisten nieuwe stijl groter dan $10 \%$. Verder komt naar voren dat havisten die verder studeren in het HBO vaak aangeven dat ze de vaardigheden zelfstandig werken, communicatieve vaardigheden en samenwerken (heel) veel nodig hebben in de vervolgopleiding (aandeel tenminste 90\%). Creativiteit en rekenvaardigheden hebben havisten relatief het minst vaak nodig in de vervolgopleiding.

Dit laatste geldt ook voor VWO'ers die doorstromen naar het HBO. Bij VWO'ers die verder gaan in het $\mathrm{HBO}$ zien we overigens wel enigszins verschil tussen schoolverlaters oude en nieuwe stijl in de mate waarin ze bepaalde vaardigheden zeggen nodig te hebben in de vervolgopleiding. Het blijkt dat schoolverlaters nu minder vaak dan voorheen zeggen dat ze taalvaardigheid en computervaardigheden nodig hebben in de vervolgopleiding (verschil tenminste 10\%).

VWO'ers oude en nieuwe stijl die verder gaan studeren in het WO verschillen weinig in de mate waarin ze de 12 algemene vaardigheden zeggen nodig te hebben in de vervolgopleiding. Daarbij geven veel VWO'ers aan zelfstandig werken nodig te hebben in de vervolgopleiding. Zowel voor als na de invoering van de tweede fase zegt $95 \%$ van de schoolverlaters dat ze zelfstandig werken (heel) veel nodig hebben in de vervolgopleiding. Daarentegen geven maar relatief weinig VWO'ers aan creativiteit (heel) veel nodig te hebben in de WO-vervolgopleiding. 
Figuur 4.1

Aandeel HAVO/VWO-schoolverlaters oude en nieuwe stijl dat de vaardigheid (heel) veel nodig heeft in de vervolgopleiding
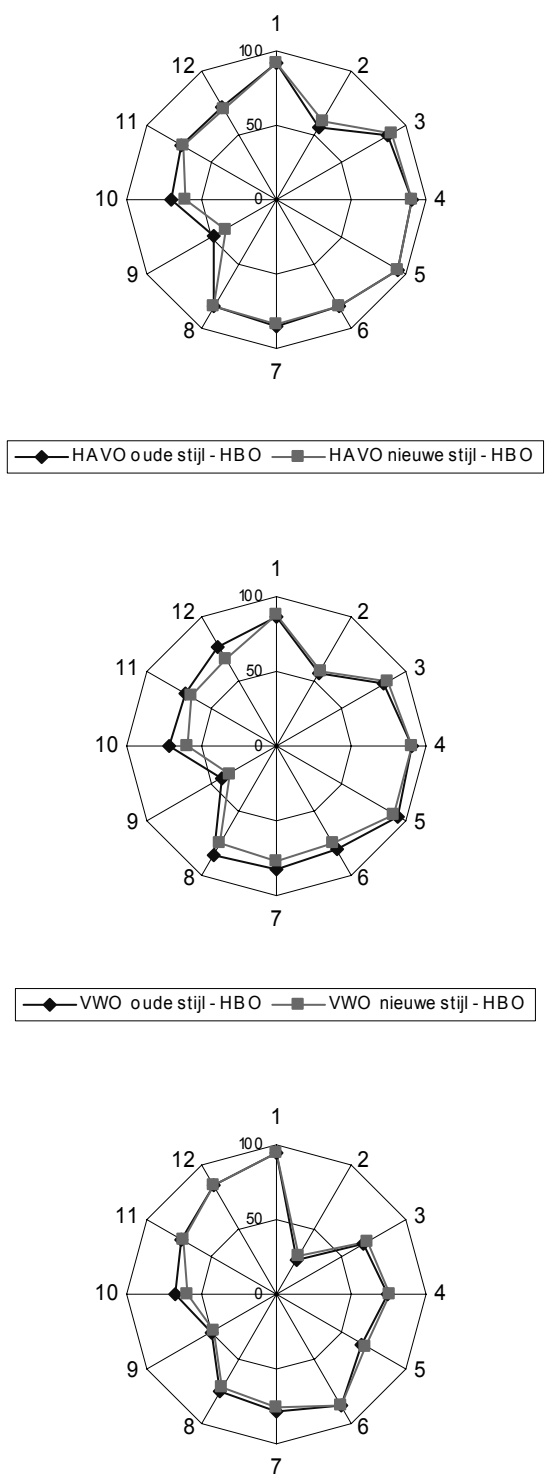

$$
\multimap-V W O \text { oude stijl - WO } \multimap-\text { VWO nieuwe stijl - WO }
$$

1) zelfstandig werken

2) creativiteit

3) initiatief

5) samenwerken

6) studieplanning

7) informatie verzamelen en verwerken

4) communicatieve vaardigheden 8) taalvaardigheid
9) rekenvaardigheden

10) computervaardigheden

11) nauwkeurig werken

12) analytische vaardighd. 
Schoolverlaters met een uiteenlopend profiel verschillen enigszins wat betreft de mate waarin ze vinden dat de vaardigheden nodig zijn in de vervolgopleiding. Tabel 4.1 laat dit zien. Vooral bij taalvaardigheid, rekenvaardigheid en computervaardigheden zijn de verschillen tussen schoolverlaters naar profiel groot. HAVO/VWOschoolverlaters met het profiel cultuur en maatschappij en economie en maatschappij zeggen taalvaardigheid vaker nodig te hebben in de vervolgopleiding dan HAVO/VWO-schoolverlaters met het profiel natuur en techniek. Havisten en VWO'ers die het profiel natuur en techniek hebben gevolgd, zeggen vaker dan havisten en VWO'ers met een ander profiel dat rekenvaardigheden en computervaardigheden nodig zijn in de vervolgopleiding.

Daarnaast komt uit tabel 4.1 naar voren dat van de havisten en VWO'ers die doorstromen naar het HBO schoolverlaters met het profiel cultuur en maatschappij het vaakst aangeven creativiteit nodig te hebben in de vervolgopleiding. Verder geldt voor VWO'ers die verder studeren in het WO dat schoolverlaters met het profiel natuur en techniek minder vaak zeggen studieplanning en informatie verzamelen en verwerken nodig te hebben in de vervolgopleiding dan schoolverlaters met een ander profiel.

Tabel 4.1

Aandeel HAVO/VWO-schoolverlaters nieuwe stijl dat de vaardigheid (heel) veel nodig heeft in de vervolgopleiding, naar profiel

$\begin{array}{llllllllllll}1 & 2 & 3 & 4 & 5 & 6 & 7 & 8 & 9 & 10 & 11 & 12\end{array}$

HAVO nieuwe stijl - HBO

cultuur en maatschappi economie en maatschappij natuur en gezondheid natuur en techniek

$\begin{array}{llllllllllll}93 & 68 & 90 & 91 & 93 & 88 & 85 & 87 & 30 & 55 & 72 & 68 \\ 91 & 58 & 90 & 91 & 93 & 81 & 84 & 84 & 40 & 62 & 69 & 71 \\ 91 & 55 & 88 & 91 & 93 & 85 & 85 & 78 & 36 & 57 & 75 & 73 \\ 92 & 58 & 85 & 84 & 93 & 79 & 78 & 65 & 63 & 80 & 73 & 74\end{array}$

VWO nieuwe stijl - HBO

cultuur en maatschappij economie en maatschappij natuur en gezondheid natuur en techniek

$\begin{array}{llllllllllll}89 & 71 & 93 & 94 & 90 & 81 & 81 & 80 & 28 & 51 & 66 & 68 \\ 87 & 51 & 89 & 91 & 91 & 73 & 79 & 82 & 38 & 65 & 64 & 68 \\ 89 & 60 & 79 & 87 & 87 & 74 & 78 & 64 & 30 & 52 & 70 & 68 \\ 87 & 50 & 84 & 81 & 93 & 63 & 60 & 57 & 54 & 75 & 63 & 66\end{array}$

VWO nieuwe stijl - WO

cultuur en maatschappij economie en maatschappij natuur en gezondheid natuur en techniek

$\begin{array}{llllllllllll}97 & 29 & 73 & 78 & 62 & 93 & 86 & 86 & 25 & 52 & 73 & 83 \\ 95 & 27 & 70 & 76 & 63 & 90 & 78 & 77 & 43 & 55 & 69 & 84 \\ 95 & 26 & 70 & 81 & 73 & 87 & 75 & 70 & 43 & 58 & 72 & 81 \\ 93 & 40 & 70 & 67 & 78 & 78 & 67 & 58 & 78 & 74 & 75 & 88\end{array}$

Antwoord 4 of 5 op een schaal van 1 (vrijwel niet) $t / m 5$ (heel veel)

$\begin{array}{ll}\text { Antwoord } 4 \text { of } 5 \text { op een schaal van } 1 \text { (vrijwel niet) } t / m 5 \text { (heel veel) } & \text { 9) rekenvaardigheden } \\ \begin{array}{lll}\text { 1) zelfstandig werken } & \text { 5) samenwerken } & \text { 10) computervaardigheden } \\ \text { 2) creativiteit } & \text { 6) studieplanning } & \text { 11) nauwkeurig werken } \\ \text { 3) initiatief } & \text { 7) informatie verzamelen en verwerken } & \text { 12) analytische vaardighd. } \\ \text { 4) communicatieve vaardigheden } & \text { 8) taalvaardigheid } & \end{array}\end{array}$

De kans dat schoolverlaters nieuwe stijl deze algemene vaardigheden (heel) veel nodig hebben in de vervolgopleiding is bovendien multivariaat onderzocht. Hiervoor is voor iedere vaardigheid afzonderlijk een analyse uitgevoerd. In tabellen 1a tot en met $1 \mathrm{c}$ van de bijlage worden de resultaten hiervan vermeld. In deze analyse wordt de kans geschat dat schoolverlaters aangeven de betreffende vaardigheid (heel) veel 
nodig te hebben in de vervolgopleiding. De resultaten van deze multivariate analyse worden hier verder niet besproken.

\section{Beheersing van vaardigheden}

Vervolgens is aan de HAVO/NWO-schoolverlaters gevraagd hoe goed ze de 12 verschillende vaardigheden beheersen (antwoordcategorieën goed, redelijk, matig en slecht). Figuur 4.2 laat het aandeel havisten en VWO'ers zien dat aangeeft de betreffende vaardigheid redelijk tot goed te beheersen. Wat meteen opvalt aan deze figuur is dat er geen grote verschillen bestaan in de mate waarin schoolverlaters oude en nieuwe stijl zeggen de 12 algemene vaardigheden te beheersen. Nergens is het verschil tussen schoolverlaters oude en nieuwe stijl groter dan $10 \%$. Bovendien blijkt uit figuur 4.1 dat het overgrote deel van de schoolverlaters van het HAVO en VWO aangeeft de verschillende vaardigheden redelijk tot goed te beheersen.

Tabel 4.2

Aandeel HAVO/VWO-schoolverlaters nieuwe stijl dat de vaardigheid redelijk tot goed beheerst, naar profiel

\begin{tabular}{|c|c|c|c|c|c|c|c|c|c|c|c|c|}
\hline & 1 & 2 & 3 & 4 & 5 & 6 & 7 & 8 & 9 & 10 & 11 & 12 \\
\hline \multicolumn{13}{|l|}{ HAVO nieuwe stijl - HBO } \\
\hline cultuur en maatschappij & 95 & 91 & 90 & 95 & 94 & 67 & 94 & 93 & 53 & 83 & 89 & 87 \\
\hline economie en maatschappij & 92 & 83 & 89 & 92 & 94 & 64 & 92 & 86 & 76 & 87 & 85 & 87 \\
\hline natuur en gezondheid & 94 & 86 & 90 & 89 & 95 & 67 & 91 & 87 & 86 & 90 & 88 & 89 \\
\hline natuur en techniek & 93 & 85 & 87 & 87 & 90 & 56 & 92 & 79 & 92 & 93 & 78 & 86 \\
\hline \multicolumn{13}{|l|}{ VWO nieuwe stijl - HBO } \\
\hline cultuur en maatschappij & 94 & 93 & 94 & 95 & 93 & 75 & 96 & 98 & 50 & 85 & 88 & 87 \\
\hline economie en maatschappij & 97 & 82 & 91 & 92 & 94 & 70 & 95 & 93 & 86 & 90 & 87 & 89 \\
\hline natuur en gezondheid & 98 & 81 & 91 & 93 & 98 & 71 & 93 & 89 & 90 & 91 & 87 & 91 \\
\hline natuur en techniek & 92 & 86 & 90 & 86 & 97 & 59 & 91 & 93 & 99 & 95 & 84 & 96 \\
\hline \multicolumn{13}{|l|}{ VWO nieuwe stijl - WO } \\
\hline cultuur en maatschappij & 95 & 86 & 87 & 92 & 94 & 71 & 96 & 95 & 51 & 81 & 88 & 89 \\
\hline economie en maatschappij & 91 & 77 & 89 & 92 & 92 & 70 & 93 & 92 & 73 & 88 & 87 & 90 \\
\hline natuur en gezondheid & 95 & 84 & 91 & 93 & 96 & 74 & 93 & 90 & 87 & 86 & 86 & 93 \\
\hline natuur en techniek & 91 & 82 & 88 & 89 & 94 & 66 & 90 & 86 & 89 & 90 & 85 & 93 \\
\hline
\end{tabular}

Antwoord 4 of 5 op een schaal van 1 (vrijwel niet) t/m 5 (heel veel)

\begin{tabular}{ll}
\hline Antwoord 4 of 5 op een schaal van 1 (vrijwel niet) t/m 5 (heel veel) \\
$\begin{array}{lll}\text { 1) zelfstandig werken } & \text { 5) samenwerken } & \text { 9) rekenvaardigheden } \\
\text { 2) creativiteit } & \text { 6) studieplanning } & \text { 10) computervaardigheden } \\
\text { 3) initiatief } & \text { 7) informatie verzamelen en verwerken } & \text { 11) nauwkeurig werken } \\
\text { 4) communicatieve vaardigheden } & \text { 8) taalvaardigheid } & \text { 12) analytische vaardighd. }\end{array}$
\end{tabular}

4) communicatieve vaardigheden 8 ) taalvaardigheid

12) analytische vaardighd.

In tabel 4.2 is voor de verschillende profielen het aandeel schoolverlaters vermeld dat zegt de 12 vaardigheiden redelijk tot goed te beheersen. Hieruit blijkt dat over het algemeen acht à negen van de tien schoolverlaters de verschillende vaardigheden redelijk tot goed beheersen. Opvallend is dat alléén bij rekenvaardigheden relatief weinig HAVO/VWO-schoolverlaters met het profiel cultuur en maatschappij vinden dat ze deze vaardigheid redelijk tot goed worden beheersen. Vooral veel HAVO/ VWO-schoolverlaters met het profiel natuur en techniek zeggen rekenvaardigheden redelijk tot goed te beheersen. Bovenstaande verschillen tussen schoolverlaters met 
het profiel cultuur en maatschappij en natuur en techniek vinden we ook voor computervaardigheden, maar dan in veel mindere mate. Dit mag min of meer ook worden verwacht, aangezien we eerder hebben gezien dat vooral schoolverlaters met het profiel natuur en techniek zeggen reken- en computervaardigheden veel nodig te hebben in de vervolgopleiding.

We hebben de kans dat schoolverlaters nieuwe stijl de vaardigheden redelijk tot goed beheersen ook multivariaat onderzocht. Voor iedere vaardigheid is afzonderlijk een analyse uitgevoerd. In tabellen $2 a$ tot en met $2 c$ van de bijlage zijn de resultaten hiervan vermeld.

Waar zijn volgens schoolverlaters de vaardigheden geleerd?

Aan de schoolverlaters is bovendien gevraagd waar ze de vaardigheden vooral hebben geleerd: in het HAVO/VWO, in de vervolgopleiding of elders. In figuur 4.3 tot en met 4.5 zijn de resultaten hiervan weergegeven. Deze figuren zijn zo opgebouwd dat de vaardigheden die door schoolverlaters oude stijl vooral in het HAVO of VWO zijn geleerd bovenaan, en de vaardigheden die door schoolverlaters oude stijl vooral in de vervolgopleiding of elders zijn opgedaan onderaan staan. In figuur 4.3 worden de resultaten gepresenteerd voor havisten die doorstromen naar het HBO.

Figuur 4.3 laat zien dat rekenvaardigheden en taalvaardigheden volgens havisten vooral worden geleerd in het HAVO. Daarbij zeggen havisten voor de invoering van de tweede fase vaker dan na de invoering dat reken- en taalvaardigheid vooral worden geleerd in het HAVO. Het tegenovergestelde zien we bij informatie verzamelen en verwerken, samenwerken, nauwkeurig werken, computervaardigheden, communicatieve vaardigheden en initiatief. Bij deze vaardigheden zien we juist dat havisten nieuwe stijl vaker aangeven dat ze deze vooral hebben opgedaan in het HAVO (verschil met havisten oude stijl tenminste 10\%). Waarschijnlijk speelt hierbij mee dat sinds de invoering van de tweede fase de nadruk minder ligt op klassikaal onderwijs en meer op vaardigheidsonderwijs. In dit verband is opvallend dat zelfstandig werken hier geen verschil laat zien tussen havisten oude en nieuwe stijl. Overigens vinden we tussen VWO'ers oude en nieuwe stijl dit verschil wel. Uit figuur 4.4 blijkt dat VWO'ers die doorstromen naar het HBO nu vaker dan voor de invoering van de tweede fase vinden dat ze zelfstandig werken vooral in het VWO hebben opgedaan (verschil tenminste 10\%). Bovendien zeggen VWO'ers die doorstromen naar het $\mathrm{HBO}$ na de invoering van de tweede fase vaker dan ervoor dat taalvaardigheid, studieplanning en samenwerken vooral in het VWO is opgedaan.

Figuur 4.5 laat een ongeveer vergelijkbaar beeld zien voor VWO'ers die verder studeren in het WO. VWO'ers nieuwe stijl geven hier vaker dan VWO'ers oude stijl aan dat samenwerken, taalvaardigheid en zelfstandig werken vooral in het VWO zijn geleerd (verschil tenminste 10\%). Voor VWO'ers geldt waarschijnlijk ook dat na de invoering van de tweede fase een verschuiving heeft plaatsgevonden van waar bepaalde vaardigheden worden geleerd. 
Figuur 4.2

Aandeel HAVO/VWO-schoolverlaters oude en nieuwe stijl dat de vaardigheid redelijk tot goed beheerst
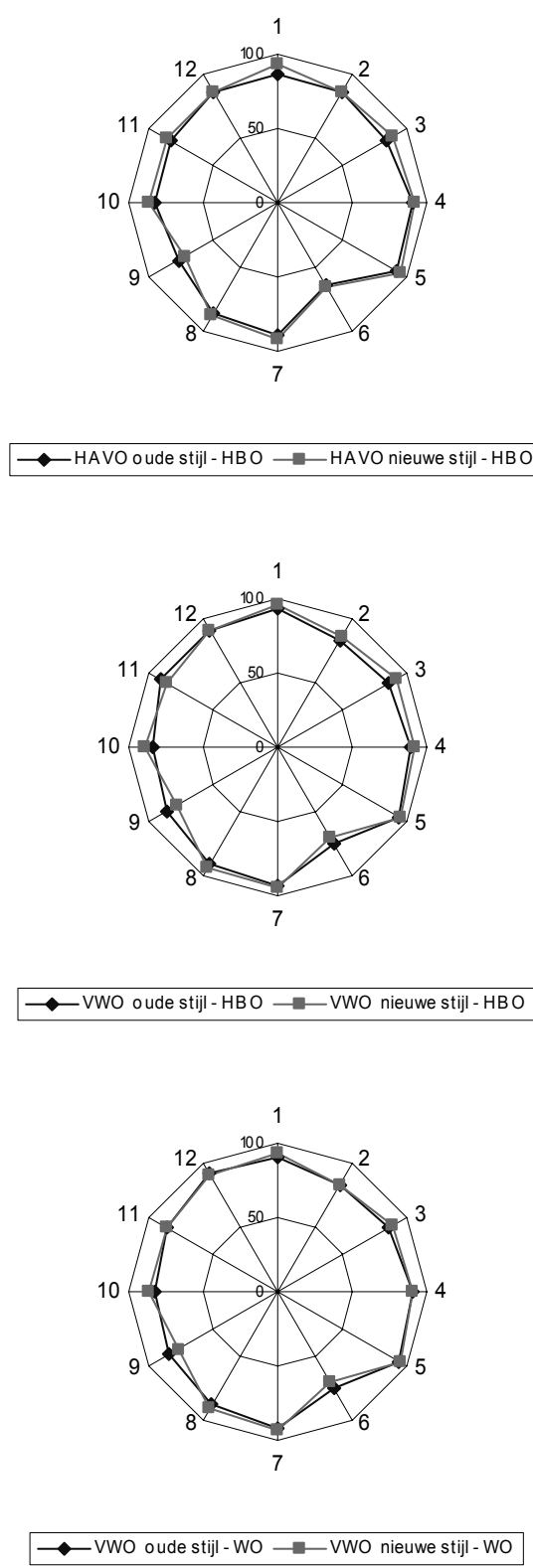
1) zelfstandig werken
5) samenwerken
9) rekenvaardigheden
2) creativiteit
6) studieplanning
10) computervaardigheden
3) initiatief
7) informatie verzamelen en verwerken
11) nauwkeurig werken
4) communicatieve vaardigheden 8) taalvaardigheid
12) analytische vaardighd. 
Figuur 4.3

De plaats waar vaardigheiden vooral zijn geleerd volgens HAVO-schoolverlaters die doorstromen naar het $\mathrm{HBO}$

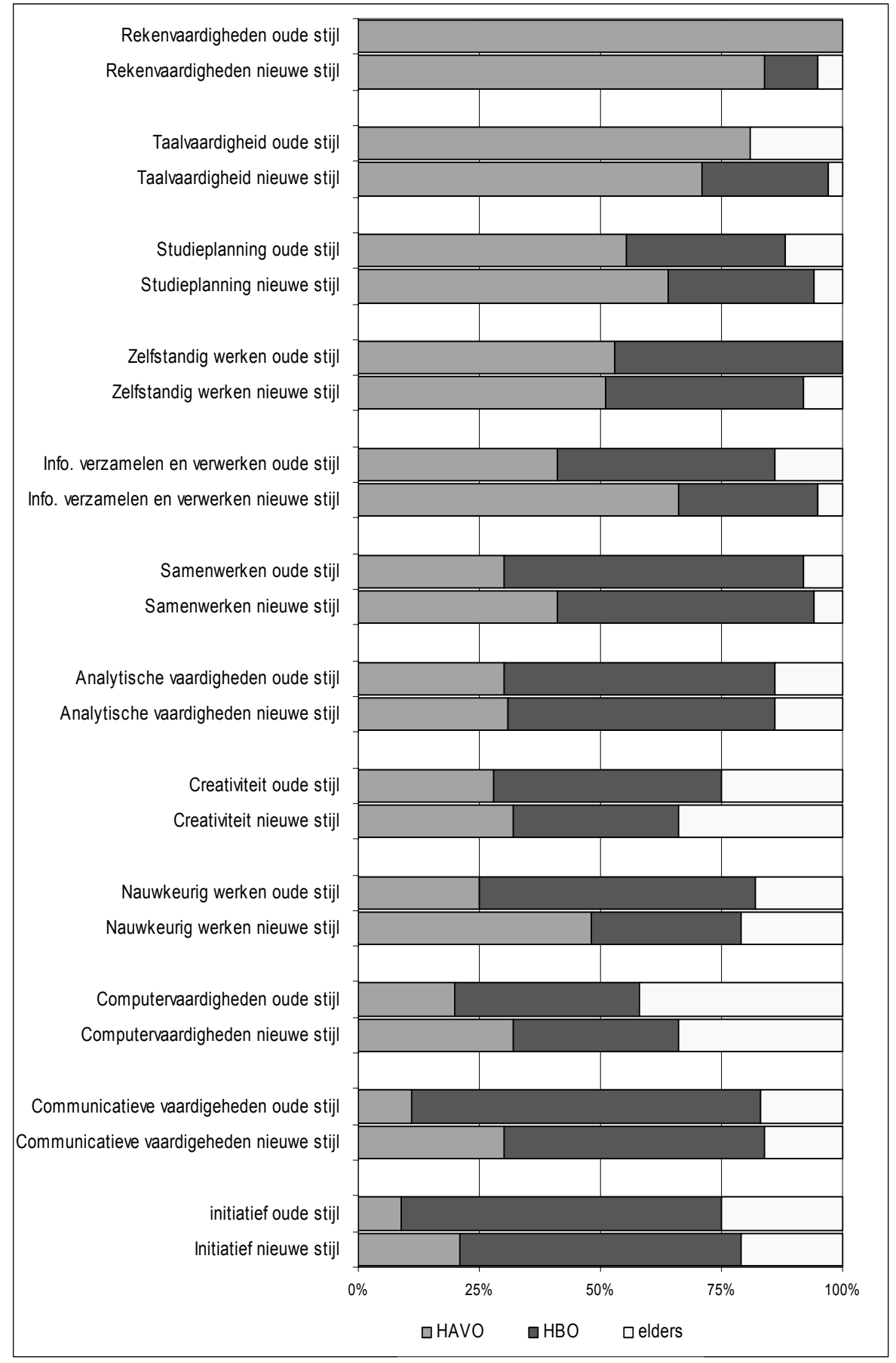


Figuur 4.4

De plaats waar vaardigheiden vooral zijn geleerd volgens VWO-schoolverlaters die doorstromen naar het $\mathrm{HBO}$

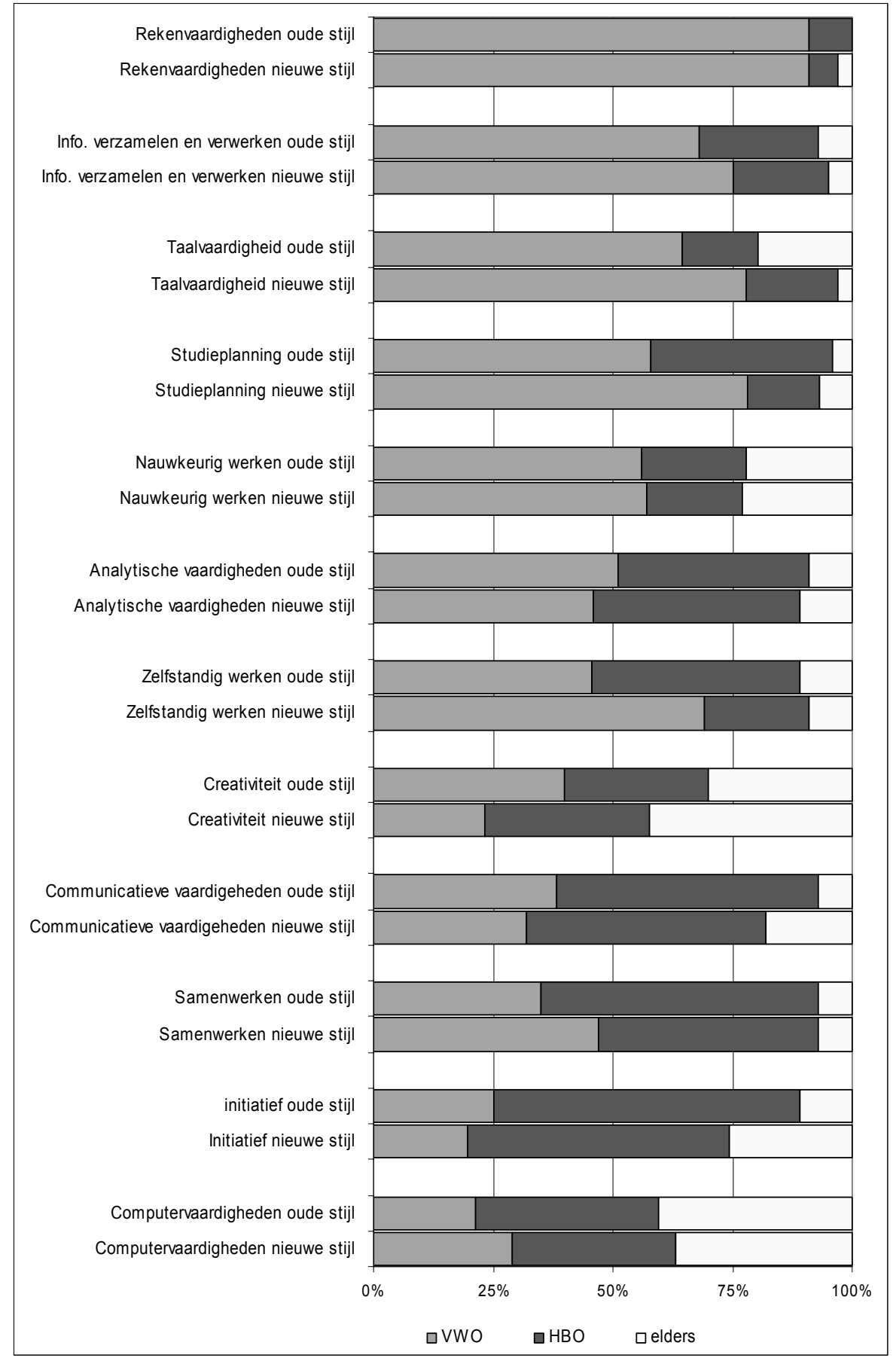


Figuur 4.5

De plaats waar vaardigheiden vooral zijn geleerd volgens VWO-schoolverlaters die doorstromen naar het WO

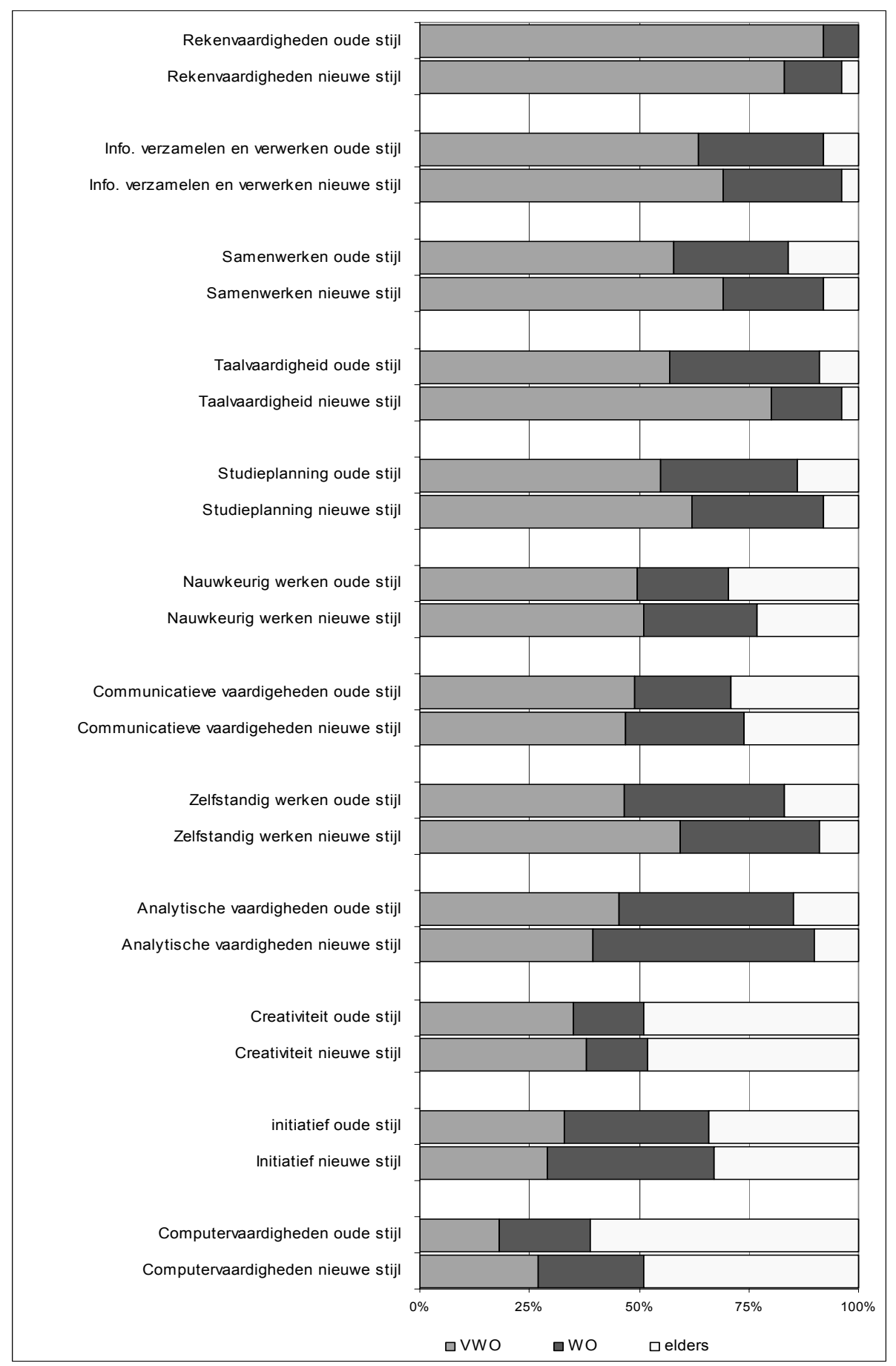


Ook voor de verschillende profielen is bekeken waar schoolverlaters de verschillende vaardigheden vooral hebben geleerd. De resultaten hiervan zijn in tabel 3 van de bijlage vermeld en worden hier verder niet besproken. Bovendien hebben we de kans dat schoolverlaters de betreffende vaardigheden hebben geleerd in de HAVO/VWO-opleiding, in de vervolgopleiding of elders multivariaat geanalyseerd. Tabellen $4 \mathrm{a}$ tot en met $4 \mathrm{c}$ van de bijlage laten de resultaten van deze analyse zien.

\section{Vaardigheden die volgens schoolverlaters meer aandacht verdienen in de opleiding}

Tot slot van dit hoofdstuk wordt ingegaan op de vraag of de verschillende vaardigheden volgens schoolverlaters voldoende aan bod zijn gekomen in de HAVO/VWOopleiding. Hiervoor is aan de HAVO/VWO-schoolverlaters gevraagd om van de 12 vaardigheden er maximaal drie te noemen waarvan zij vinden dat in de opleiding meer aandacht moet worden besteed. Voor elke vaardigheid is bepaald hoe vaak deze is genoemd door de schoolverlaters. Deze percentages zijn voor de 12 vaardigheden vermeld in figuur 4.6.

Uit figuur 4.6 blijkt dat havisten oude stijl op een aantal vaardigheden verschillen van havisten nieuwe stijl. Hierbij geldt dat havisten voor de invoering van de tweede fase vaker dan na de invoering zeggen dat in de HAVO-opleiding meer aandacht had moeten worden besteed aan zelfstandig werken en computervaardigheden. Voor zelfstandig werken en computervaardigheden geldt dat bijna $40 \%$ van de havisten oude stijl zegt dat deze meer aandacht verdienen in de opleiding. Bij havisten nieuwe stijl wordt dit door respectievelijk $29 \%$ en $22 \%$ van de schoolverlaters gezegd. De invoering van de tweede fase in het voortgezet onderwijs had onder meer tot doel de zelfstandigheid van de leerlingen te verhogen. Bovenstaande cijfers met betrekking tot zelfstandig werken lijken aan te geven dat de zelfstandigheid volgens de perceptie van schoolverlaters van het HAVO inderdaad is toegenomen.

Gevolg van het feit dat maximaal drie vaardigheden mogen worden genoemd waaraan onvoldoende aandacht is besteed in de opleiding, is dat schoolverlaters na de invoering van de tweede fase vaker andere vaardigheden dan zelfstandig werken zullen noemen. Het blijkt dat havisten nu vaker dan vroeger aangeven dat initiatief, communicatieve vaardigheden en nauwkeurig werken meer aandacht verdienen in de opleiding. Van de havisten oude stijl zegt $23 \%$ dat initiatief, $32 \%$ dat communicatieve vaardigheden en $8 \%$ dat nauwkeurig werken onvoldoende aan bod is gekomen. Voor havisten nieuwe stijl zijn deze percentages respectievelijk $32 \%$, $38 \%$ en $14 \%$.

Bij VWO'ers die doorstromen naar het HBO doen de grootste verschillen tussen schoolverlaters oude en nieuwe stijl zich hier voor bij zelfstandig werken, creativiteit, initiatief, samenwerken, computervaardigheden en analytische vaardigheden (verschil > 5\%). Deze VWO'ers geven na de invoering van de tweede fase minder vaak dan vroeger aan dat meer aandacht had moeten worden besteed aan zelfstandig werken en computervaardigheden in de opleiding. Volgens de perceptie van schoolverlaters is ook hier dus de zelfstandigheid van schoolverlaters toegenomen. Bovendien vinden VWO'ers nu minder vaak dan voorheen dat 
samenwerken te weinig aan bod is gekomen in het VWO. Daartegenover staat dat VWO'ers tegenwoordig vaker zeggen dat creativiteit, initiatief en analytische vaardigheden onvoldoende aan bod zijn gekomen in de opleiding.

Voor VWO'ers die verder gaan in het WO geldt dat er zich weinig grote verschillen voordoen tussen schoolverlaters oude en nieuwe stijl in de mate waarin zij vinden dat er meer aandacht zou moeten worden besteed aan de verschillende vaardigheden in de opleiding. Alléén bij computervaardigheden zeggen schoolverlaters oude stijl (38\%) duidelijk vaker dan schoolverlaters nieuwe stijl $(25 \%)$ dat deze te weinig aan bod is gekomen. Hieruit kan worden geconcludeerd dat voor alle groepen schoolverlaters van het HAVO en VWO geldt dat na de invoering van de tweede fase minder schoolverlaters zeggen dat computervaardigheden te weinig aan bod zijn gekomen in de opleiding.

In tabel 4.3 is de mate waarin schoolverlaters vinden dat aan bepaalde vaardigheden meer aandacht moet worden besteed in de opleiding voor de verschillende profielen weergegeven. Bij het HAVO zien we maar weinig verschillen tussen de profielen. Een uitzondering is dat relatief veel havisten met het profiel natuur en techniek samenwerken noemen (49\%).

Tabel 4.3

Aandeel HAVO/VWO-schoolverlaters nieuwe stijl dat aangeeft dat aan de vaardigheid meer aandacht moet worden besteed in de HAVO/VWO opleiding, naar profiel

\begin{tabular}{|c|c|c|c|c|c|c|c|c|c|c|c|c|}
\hline & 1 & 2 & 3 & 4 & 5 & 6 & 7 & 8 & 9 & 10 & 11 & 12 \\
\hline \multicolumn{13}{|l|}{ HAVO nieuwe stijl - HBO } \\
\hline cultuur en maatschappij & 27 & 18 & 35 & 37 & 36 & 31 & 14 & 15 & 8 & 22 & 12 & 18 \\
\hline economie en maatschappij & 29 & 16 & 28 & 40 & 38 & 29 & 15 & 15 & 8 & 22 & 16 & 19 \\
\hline natuur en gezondheid & 33 & 16 & 34 & 40 & 33 & 37 & 13 & 12 & 4 & 20 & 13 & 18 \\
\hline natuur en techniek & 28 & 14 & 32 & 33 & 49 & 29 & 11 & 12 & 8 & 25 & 15 & 17 \\
\hline \multicolumn{13}{|l|}{ VWO nieuwe stijl - HBO } \\
\hline cultuur en maatschappij & 12 & 28 & 41 & 35 & 36 & 19 & 12 & 8 & 6 & 26 & 12 & 29 \\
\hline economie en maatschappij & 14 & 28 & 33 & 43 & 33 & 20 & 13 & 19 & 6 & 31 & 7 & 23 \\
\hline natuur en gezondheid & 18 & 28 & 38 & 41 & 26 & 20 & 17 & 17 & 3 & 15 & 10 & 23 \\
\hline natuur en techniek & 25 & 15 & 38 & 41 & 35 & 24 & 6 & 11 & 6 & 23 & 11 & 22 \\
\hline \multicolumn{13}{|l|}{ VWO nieuwe stijl - WO } \\
\hline cultuur en maatschappij & 32 & 16 & 29 & 24 & 12 & 35 & 26 & 17 & 8 & 25 & 14 & 33 \\
\hline economie en maatschappij & 29 & 15 & 25 & 29 & 13 & 31 & 18 & 16 & 14 & 23 & 15 & 34 \\
\hline natuur en gezondheid & 25 & 17 & 28 & 33 & 15 & 28 & 18 & 16 & 6 & 26 & 17 & 25 \\
\hline natuur en techniek & 25 & 18 & 30 & 26 & 20 & 28 & 11 & 12 & 20 & 24 & 13 & 28 \\
\hline
\end{tabular}

Antwoord 4 of 5 op een schaal van 1 (vrijwel niet) $t / m 5$ (heel veel)
1) zelfstandig werken
5) samenwerken
9) rekenvaardigheden
2) creativiteit
6) studieplanning
10) computervaardigheden
3) initiatief
7) informatie verzamelen en verwerken
11) nauwkeurig werken

4) communicatieve vaardigheden 8) taalvaardigheid

12) analytische vaardighd. 
Figuur 4.6

Aandeel HAVO/VWO-schoolverlaters oude en nieuwe stijl dat aangeeft dat aan de vaardigheid meer aandacht moet worden besteed in de HAVO/VWO opleiding
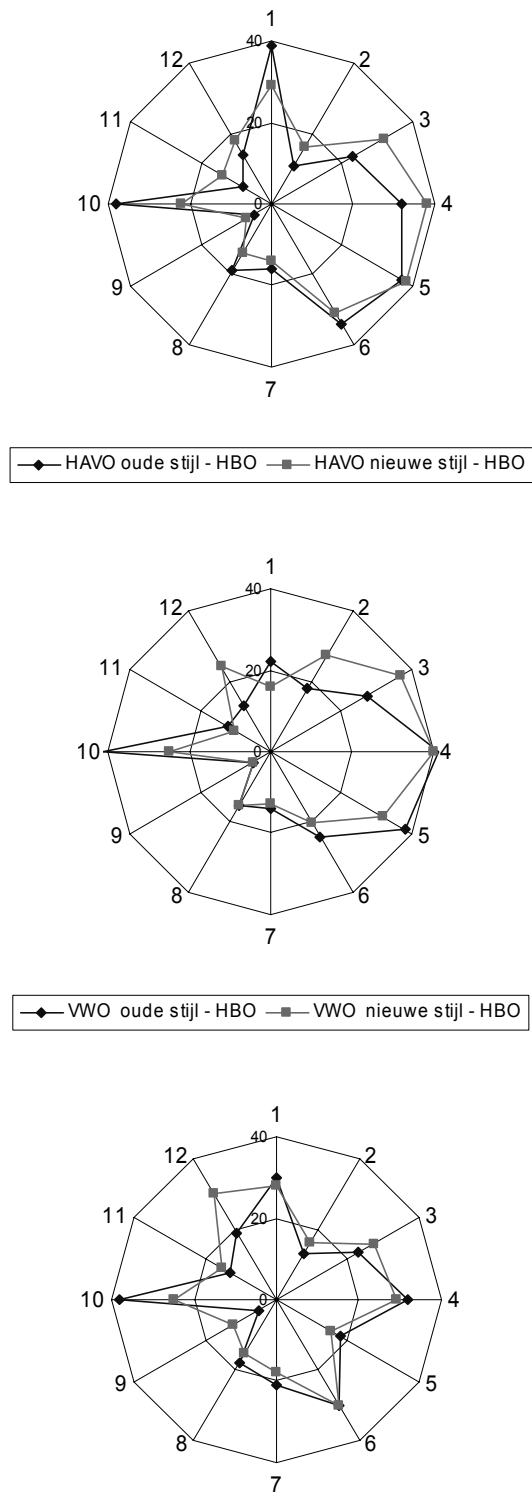

$\multimap-$ WWO oude stijl - WO - WWO nieuwe stij - WO
1) zelfstandig werken
5) samenwerken
9) rekenvaardigheden
2) creativiteit
6) studieplanning
10) computervaardigheden
3) initiatief
7) informatie verzamelen en verwerken
11) nauwkeurig werken
4) communicatieve vaardigheden 8) taalvaardigheid
12) analytische vaardighd. 
Ook voor VWO'ers die verder studeren in het WO geldt dat er zich weinig verschillen voordoen naar profiel. Voor VWO'ers die doorgaan in het HBO geldt dat vooral VWO'ers met een ander profiel dan natuur en techniek zeggen dat creativiteit onvoldoende aan bod is gekomen in de VWO-opleiding. VWO'ers met het profiel natuur en techniek vinden vaker dan VWO'ers met een ander profiel dat aan zelfstandig werken meer aandacht had moeten worden besteed in de opleiding. Verder zeggen VWO'ers met het profiel natuur en gezondheid minder vaak dan VWO'ers met een ander profiel dat computervaardigheden onvoldoende aan bod zijn gekomen.

Tabel 4.4

Multivariate analyse van de kans dat schoolverlaters aangeven dat aan de vaardigheid meer aandacht moet worden besteed in de HAVO opleiding

\begin{tabular}{|c|c|c|c|c|c|c|c|c|c|c|c|c|}
\hline HAVO nieuwe stijl - HBO & 1 & 2 & 3 & 4 & 5 & 6 & 7 & 8 & 9 & 10 & 11 & 12 \\
\hline \multicolumn{13}{|l|}{ Geslacht } \\
\hline vrouw & ref. & ref. & ref. & ref. & ref. & ref. & ref. & ref. & ref. & ref. & ref. & ref. \\
\hline man & 0 & 0 & 0 & 0 & 0 & + & 0 & 0 & 0 & - & + & 0 \\
\hline \multicolumn{13}{|l|}{ Profiel } \\
\hline cultuur en maatschappij & 0 & 0 & 0 & 0 & 0 & 0 & 0 & 0 & + & 0 & 0 & 0 \\
\hline economie en maatschappij & ref. & ref. & ref. & ref. & ref. & ref. & ref. & ref. & ref. & ref. & ref. & ref. \\
\hline natuur en gezondheid & 0 & 0 & 0 & 0 & 0 & 0 & 0 & 0 & 0 & 0 & + & 0 \\
\hline natuur en techniek & 0 & 0 & 0 & 0 & 0 & 0 & 0 & 0 & 0 & 0 & 0 & 0 \\
\hline Profieloverstap & 0 & 0 & 0 & 0 & 0 & 0 & 0 & 0 & 0 & 0 & 0 & 0 \\
\hline Gemiddeld examencijfer & - & 0 & 0 & 0 & 0 & - & 0 & 0 & - & 0 & 0 & + \\
\hline \multicolumn{13}{|l|}{ Hoogst behaalde vooropleiding } \\
\hline geen & ref. & ref. & ref. & ref. & ref. & ref. & ref. & ref. & ref. & ref. & ref. & ref. \\
\hline mavo & 0 & 0 & 0 & 0 & 0 & 0 & 0 & 0 & 0 & 0 & 0 & 0 \\
\hline anders & 0 & 0 & 0 & 0 & 0 & 0 & 0 & + & 0 & 0 & 0 & 0 \\
\hline Duur havo opleiding & 0 & 0 & 0 & 0 & 0 & + & 0 & - & 0 & + & 0 & 0 \\
\hline \multicolumn{13}{|l|}{ Sector vervolgopleiding } \\
\hline landbouw & 0 & 0 & 0 & 0 & - & 0 & 0 & 0 & 0 & 0 & 0 & 0 \\
\hline onderwijs & 0 & + & + & 0 & - & + & 0 & - & 0 & - & 0 & 0 \\
\hline techniek & 0 & 0 & 0 & 0 & 0 & 0 & 0 & 0 & 0 & 0 & 0 & 0 \\
\hline economie & ref. & ref. & ref. & ref. & ref. & ref. & ref. & ref. & ref. & ref. & ref. & ref. \\
\hline gezondheidszorg & + & 0 & 0 & 0 & - & 0 & + & - & - & - & 0 & 0 \\
\hline gedrag en maatschappij & 0 & 0 & 0 & + & 0 & 0 & 0 & 0 & - & - & 0 & + \\
\hline taal en cultuur & 0 & + & 0 & 0 & - & 0 & 0 & 0 & 0 & 0 & 0 & 0 \\
\hline \multicolumn{13}{|c|}{$\begin{array}{l}\text { ref.= referentie } \\
-=\text { negatief significant effect op } 5 \% \text {-niveau } \\
0=\text { geen significant effect op } 5 \% \text {-niveau } \\
+=\text { positief significant effect op } 5 \% \text {-niveau }\end{array}$} \\
\hline 1) zelfstandig werken & \multicolumn{7}{|c|}{ 5) samenwerken } & \multicolumn{5}{|c|}{ 9) rekenvaardigheden } \\
\hline 2) creativiteit & \multicolumn{7}{|c|}{ 6) studieplanning } & \multirow{2}{*}{\multicolumn{5}{|c|}{$\begin{array}{l}\text { 10) computervaardigheden } \\
\text { 11) nauwkeurig werken } \\
\text { 12) analytische vaardighd. }\end{array}$}} \\
\hline $\begin{array}{l}\text { 3) initiatief } \\
\text { 4) communicatieve vaardigheden } 8\end{array}$ & $\begin{array}{l}\text { inform } \\
\text { taalva }\end{array}$ & $\begin{array}{l}\text { atie ve } \\
\text { ardigh }\end{array}$ & erzame & elen er & $n$ verw & rerken & & & & & & \\
\hline
\end{tabular}

De mate waarin schoolverlaters vinden dat de vaardigheden meer aandacht verdienen in de opleiding hebben we ook multivariaat geanalyseerd. Hiervoor hebben we voor elke vaardigheid afzonderlijk de kans bepaald dat HAVO/VWOschoolverlaters zeggen dat de betreffende vaardigheid meer aandacht verdient in de opleiding. In tabel 4.4 zijn de resultaten hiervan weergegeven voor schoolverlaters van het HAVO die doorstromen naar het HBO. Verschillende kenmerken zijn hier van 
invloed. Zo komt naar voren dat geslacht een positief significant effect heeft bij studieplanning en nauwkeurig werken, en een negatief significant effect bij computervaardigheden. Dit houdt in dat mannen vaker zeggen dat er meer aandacht moet worden besteed aan studieplanning en nauwkeurig werken, terwijl vrouwen vaker aangeven dat er meer aandacht moet worden besteed aan computervaardigheden in de HAVO-opleiding. Daarnaast blijkt dat havisten met het profiel cultuur en maatschappij vaker zeggen dat rekenvaardigheden meer aandacht hadden verdiend in de opleiding. Hetzelfde geldt bij nauwkeurig werken voor havisten die het profiel natuur en gezondheid hebben gevolgd. Ook het eindexamencijfer van havisten doet er hier toe. Havisten die gemiddeld een laag eindexamencijfer hebben behaald, vinden significant vaker dat meer aandacht had moeten worden besteed in de opleiding aan zelfstandig werken, studieplanning en rekenvaardigheden. Havisten met een hoog gemiddeld eindexamencijfer vinden vaker dat er meer aandacht had moeten worden besteed aan analytische vaardigheden.

Verder laten de hoogst behaalde vooropleiding en de duur van de HAVO-opleiding een significant effect zien bij studieplanning, taalvaardigheid en computervaardigheden. Havisten met een andere vooropleiding dan het MAVO zeggen vaker dat er meer aandacht had moeten worden besteed aan taalvaardigheid in de HAVOopleiding. Havisten die relatief lang over de HAVO-opleiding hebben gedaan zeggen vaker dat meer aandacht had moeten worden besteed aan studieplanning en computervaardigheden, en minder vaak dat meer aandacht had moeten worden besteed aan taalvaardigheid. Tot slot blijkt dat de sector van de vervolgopleiding een belangrijke rol speelt bij de mate waarin havisten vinden dat bepaalde vaardigheden voldoende aan bod zijn gekomen in de opleiding. Havisten die kiezen voor een vervolgopleiding in de sector landbouw zeggen minder vaak dat meer aandacht moet worden besteed aan samenwerken. Havisten die verder gaan in de sector onderwijs geven relatief vaak aan dat meer aandacht moet worden besteed aan creativiteit, initiatief en studieplanning. Voor havisten die kiezen voor de sector gezondheidszorg geldt dat ze relatief vaak aangeven dat zelfstandig werken en informatie verzamelen en verwerken te weinig aan bod zijn gekomen. Havisten die verder gaan in de sector gedrag en maatschappij geven relatief vaak aan dat communicatieve vaardigheden en analytische vaardigheden onvoldoende aan bod zijn gekomen. Havisten die kiezen voor de sector taal en cultuur vinden relatief vaak dat er meer aandacht moet worden besteed aan creativiteit.

Bij VWO'ers die doorstromen naar het HBO (zie tabel 4.5) geldt dat mannen vaker aangeven dat in de VWO-opleiding meer aandacht had moeten worden besteed aan nauwkeurig werken. Daarnaast zien we dat schoolverlaters met het profiel cultuur en maatschappij en natuur en gezondheid relatief vaak zeggen dat meer aandacht moet worden besteed aan initiatief. Bovendien vinden veel schoolverlaters met het profiel cultuur en maatschappij dat samenwerken onvoldoende aan bod is gekomen in de VWO-opleiding. Ook voor VWO'ers die verder gaan in het HBO geldt dat het gemiddeld eindexamencijfer hier van invloed is. VWO'ers die een relatief hoog cijfer hebben behaald, zeggen vaker dat creativiteit en initiatief onvoldoende aan bod zijn 
gekomen, en minder vaak dat meer aandacht had moeten worden besteed aan rekenvaardigheid in de opleiding. Wat betreft de sector van de vervolgopleiding geldt dat VWO'ers die doorstromen naar een opleiding in het HBO onderwijs relatief vaak zeggen dat rekenvaardigheid en nauwkeurig werken onvoldoende aan bod is gekomen in het VWO. VWO'ers die doorstromen naar een HBO-opleiding in de sector techniek geven vaak aan dat meer aandacht moet worden besteed aan rekenen computervaardigheden. Net als bij havisten zien we dat VWO'ers die kiezen voor een HBO opleiding in de sector taal en cultuur vaak aangeven dat er meer aandacht had moeten worden besteed aan creativiteit.

Tabel 4.5

Multivariate analyse van de kans dat schoolverlaters aangeven dat aan de vaardigheid meer aandacht moet worden besteed in de VWO opleiding

\begin{tabular}{|c|c|c|c|c|c|c|c|c|c|c|c|c|}
\hline VWO nieuwe stijl - HBO & 1 & 2 & 3 & 4 & 5 & 6 & 7 & 8 & 9 & 10 & 11 & 12 \\
\hline \multicolumn{13}{|l|}{ Geslacht } \\
\hline vrouw & ref. & ref. & ref. & ref. & ref. & ref. & ref. & ref. & ref. & ref. & ref. & ref. \\
\hline man & 0 & 0 & 0 & 0 & 0 & 0 & 0 & 0 & 0 & 0 & + & 0 \\
\hline \multicolumn{13}{|l|}{ Profiel } \\
\hline cultuur en maatschappij & 0 & 0 & + & 0 & + & 0 & 0 & 0 & 0 & 0 & 0 & 0 \\
\hline economie en maatschappij & ref. & ref. & ref. & ref. & ref. & ref. & ref. & ref. & ref. & ref. & ref. & ref. \\
\hline natuur en gezondheid & 0 & 0 & + & 0 & 0 & 0 & 0 & 0 & 0 & 0 & 0 & 0 \\
\hline natuur en techniek & 0 & 0 & 0 & 0 & 0 & 0 & 0 & 0 & 0 & - & 0 & 0 \\
\hline Profieloverstap & 0 & 0 & 0 & 0 & 0 & 0 & 0 & 0 & 0 & 0 & 0 & 0 \\
\hline Gemiddeld examencijfer & 0 & + & + & 0 & 0 & 0 & 0 & 0 & - & 0 & 0 & 0 \\
\hline geen & ref. & ref. & ref. & ref. & ref. & ref. & ref. & ref. & ref. & ref. & ref. & ref. \\
\hline havo & 0 & 0 & 0 & 0 & 0 & 0 & 0 & 0 & 0 & 0 & + & 0 \\
\hline anders & 0 & 0 & 0 & 0 & 0 & 0 & 0 & 0 & + & 0 & 0 & 0 \\
\hline Duur vwo opleiding & 0 & 0 & - & 0 & 0 & 0 & 0 & 0 & 0 & 0 & 0 & 0 \\
\hline \multicolumn{13}{|l|}{ Sector vervolgopleiding } \\
\hline landbouw & 0 & 0 & 0 & 0 & 0 & 0 & 0 & 0 & 0 & 0 & 0 & 0 \\
\hline onderwijs & 0 & 0 & 0 & 0 & 0 & 0 & 0 & 0 & + & 0 & + & 0 \\
\hline techniek & 0 & 0 & 0 & - & 0 & 0 & 0 & 0 & + & + & 0 & 0 \\
\hline economie & ref. & ref. & ref. & ref. & ref. & ref. & ref. & ref. & ref. & ref. & ref. & ref. \\
\hline gezondheidszorg & 0 & 0 & 0 & 0 & 0 & 0 & 0 & 0 & 0 & - & 0 & 0 \\
\hline gedrag en maatschappij & 0 & 0 & 0 & 0 & 0 & 0 & 0 & 0 & 0 & - & 0 & 0 \\
\hline taal en cultuur & 0 & + & 0 & 0 & - & 0 & 0 & 0 & 0 & 0 & 0 & 0 \\
\hline
\end{tabular}

ref.= referentie

- = negatief significant effect op 5\%-niveau

$0=$ geen significant effect op $5 \%$-niveau

$+=$ positief significant effect op $5 \%$-niveau

$\begin{array}{lll}\text { 1) zelfstandig werken } & 5 \text { ) samenwerken } & 9 \text { ) rekenvaardigheden }\end{array}$

$\begin{array}{lll}2) \text { creativiteit } & 6) \text { studieplanning } & \text { 10) computervaardigheden }\end{array}$

$\begin{array}{lll}3) \text { initiatief } & 7 \text { ) informatie verzamelen en verwerken 11) nauwkeurig werken }\end{array}$

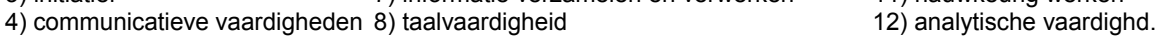

Voor VWO'ers die doorstromen naar het WO (tabel 4.6) geldt dat mannen vaker zeggen dat in de VWO-opleiding meer aandacht had moeten worden besteed aan zelfstandig werken, nauwkeurig werken en analytische vaardigheden. Vrouwen vinden daarentegen vaker dat meer aandacht had moeten worden besteed aan computervaardigheden in de VWO-opleiding. Verder vinden VWO'ers met het profiel cultuur en maatschappij relatief vaak dat zelfstandig werken onvoldoende aan bod is 
gekomen in de opleiding. VWO'ers met het profiel natuur en techniek geven vaak aan dat initiatief onvoldoende aan bod is gekomen in de opleiding. Daarnaast blijkt dat VWO'ers die een profieloverstap hebben gemaakt vaak aangeven dat creativiteit onvoldoende aan bod is gekomen in de VWO-opleiding. Naarmate VWO'ers die verder gaan in het WO een hoger gemiddeld cijfer hebben behaald, geven ze vaker aan dat in de opleiding meer aandacht had moeten worden besteed aan creativiteit en computervaardigheden. VWO'ers met een laag eindexamencijfer geven daarentegen vaker aan dat meer tijd aan zelfstandig werken en studieplanning had moeten worden besteed. VWO'ers die verder gaan in een WO-opleiding in de sector gedrag en maatschappij of de sector taal en cultuur vinden vaak dat meer aandacht had moeten worden besteed aan creativiteit en informatie verzamelen. VWO'ers die kiezen voor een WO-opleiding in de sector recht en openbare orde geven vaak aan dat in de VWO-opleiding meer aandacht had moeten worden besteed aan studieplanning.

Tabel 4.6

Multivariate analyse van de kans dat schoolverlaters aangeven dat aan de vaardigheid meer aandacht moet worden besteed in de VWO opleiding

\begin{tabular}{|c|c|c|c|c|c|c|c|c|c|c|c|c|}
\hline VWO nieuwe stijl - WO & 1 & 2 & 3 & 4 & 5 & 6 & 7 & 8 & 9 & 10 & 11 & 12 \\
\hline \multicolumn{13}{|l|}{ Geslacht } \\
\hline vrouw & ref. & ref. & ref. & ref. & ref. & ref. & ref. & ref. & ref. & ref. & ref. & ref. \\
\hline man & + & 0 & 0 & 0 & 0 & 0 & 0 & 0 & 0 & - & + & + \\
\hline \multicolumn{13}{|l|}{ Profiel } \\
\hline cultuur en maatschappij & + & 0 & 0 & 0 & 0 & 0 & 0 & 0 & 0 & 0 & 0 & 0 \\
\hline economie en maatschappij & ref. & ref. & ref. & ref. & ref. & ref. & ref. & ref. & ref. & ref. & ref. & ref. \\
\hline natuur en gezondheid & 0 & 0 & 0 & 0 & 0 & 0 & 0 & 0 & - & 0 & 0 & - \\
\hline natuur en techniek & 0 & 0 & + & 0 & 0 & 0 & 0 & 0 & 0 & 0 & 0 & - \\
\hline Profieloverstap & 0 & + & 0 & 0 & 0 & 0 & 0 & 0 & 0 & 0 & 0 & 0 \\
\hline Gemiddeld examencijfer & - & + & 0 & 0 & 0 & - & 0 & 0 & 0 & + & 0 & 0 \\
\hline \multicolumn{9}{|l|}{ Hoogst behaalde vooropleiding } & ref. & ref. & ref. & ref. \\
\hline havo & 0 & 0 & 0 & 0 & 0 & 0 & 0 & 0 & 0 & 0 & 0 & 0 \\
\hline anders & 0 & 0 & 0 & 0 & 0 & 0 & 0 & 0 & 0 & 0 & 0 & 0 \\
\hline Duur vwo opleiding & 0 & 0 & 0 & 0 & 0 & 0 & 0 & 0 & 0 & 0 & 0 & 0 \\
\hline \multicolumn{13}{|l|}{ Sector vervolgopleiding } \\
\hline landbouw & 0 & 0 & 0 & 0 & 0 & 0 & 0 & 0 & 0 & 0 & 0 & 0 \\
\hline techniek & 0 & 0 & 0 & - & 0 & 0 & 0 & 0 & 0 & 0 & 0 & 0 \\
\hline economie & ref. & ref. & ref. & ref. & ref. & ref. & ref. & ref. & ref. & ref. & ref. & ref. \\
\hline gezondheidszorg & 0 & 0 & 0 & 0 & 0 & 0 & 0 & 0 & 0 & - & 0 & 0 \\
\hline gedrag en maatschappij & 0 & + & 0 & 0 & 0 & 0 & + & 0 & - & - & 0 & 0 \\
\hline taal en cultuur & 0 & + & 0 & - & 0 & 0 & + & 0 & - & - & + & 0 \\
\hline recht en openbare orde & 0 & 0 & 0 & 0 & - & + & 0 & 0 & - & - & + & 0 \\
\hline natuurwetenschappen & 0 & 0 & 0 & - & 0 & 0 & 0 & 0 & 0 & 0 & 0 & 0 \\
\hline \multicolumn{13}{|c|}{$\begin{array}{l}\text { ref.= referentie } \\
-=\text { negatief significant effect op } 5 \% \text {-niveau } \\
0=\text { geen significant effect op } 5 \% \text {-niveau } \\
+=\text { positief significant effect op } 5 \% \text {-niveau }\end{array}$} \\
\hline 1) zelfstandig werken & \multicolumn{7}{|c|}{ 5) samenwerken } & \multicolumn{5}{|c|}{ 9) rekenvaardigheden } \\
\hline 2) creativiteit & \multicolumn{7}{|c|}{ 6) studieplanning } & \multicolumn{5}{|c|}{ 10) computervaardigheden } \\
\hline 3) initiatief & \multicolumn{7}{|c|}{ 7) informatie verzamelen en verwerken } & \multicolumn{5}{|c|}{ 11) nauwkeurig werken } \\
\hline \multicolumn{8}{|c|}{ 4) communicatieve vaardigheden 8) taalvaardigheid } & \multicolumn{5}{|c|}{ 12) analytische vaardighd. } \\
\hline
\end{tabular}




\section{De keuze voor de vervolgopleiding achteraf gezien}

In dit hoofdstuk staat de vraag centraal of schoolverlaters achteraf gezien opnieuw zouden kiezen voor dezelfde vervolgopleiding. In tabel 5.1 is vermeld of schoolverlaters van het HAVO en VWO opnieuw zouden kiezen voor dezelfde vervolgopleiding, en zo ja of ze deze vervolgopleiding aan dezelfde instelling of aan een andere instelling zouden willen volgen. Hieruit blijkt dat schoolverlaters nieuwe stijl gemiddeld wat vaker dan schoolverlaters oude stijl aangeven achteraf gezien dezelfde opleiding aan dezelfde instelling te zullen kiezen. Het aandeel schoolverlaters dat zegt dezelfde vervolgopleiding aan een andere instelling te willen volgen en het aandeel schoolverlaters dat zegt een andere vervolgopleiding te willen volgen is iets gedaald na de invoering van de tweede fase.

Tabel 5.1

Aandeel HAVO/VWO-schoolverlaters oude en nieuwe stijl dat de vervolgopleiding achteraf gezien opnieuw zou kiezen

\begin{tabular}{lcccc}
\hline & $\begin{array}{c}\text { Ja, zelfde } \\
\text { vervolg- } \\
\text { opleiding } \\
\text { aan zelfde } \\
\text { instelling }\end{array}$ & $\begin{array}{c}\text { Ja, zelfde } \\
\text { vervolg- } \\
\text { opleiding } \\
\text { aan andere } \\
\text { instelling }\end{array}$ & $\begin{array}{c}\text { Nee, } \\
\text { andere } \\
\text { vervolg- } \\
\text { opleiding }\end{array}$ & $\begin{array}{c}\text { Nee, } \\
\text { geen } \\
\text { vervolg- } \\
\text { opleiding }\end{array}$ \\
\hline HAVO oude stijl - HBO & 69 & 10 & 20 & 1 \\
VWO oude stijl - HBO & 78 & 8 & 14 & 0 \\
VWO oude stijl - WO & 81 & 5 & 14 & 1 \\
HAVO nieuwe stijl - HBO & 75 & 8 & 17 & 1 \\
VWO nieuwe stijl - HBO & 82 & 6 & 11 & 0 \\
VWO nieuwe stijl - WO & 83 & 4 & 14 & 0 \\
\hline
\end{tabular}

In tabel 5.2 is de keuze voor de opleiding achteraf gezien weergegeven voor de verschillende profielen. We zien dat schoolverlaters wat dit betreft enigszins verschillen. Opvallend daarbij is dat HAVO- en VWO-schoolverlaters die verder studeren in het $\mathrm{HBO}$ en het profiel economie en maatschappij hebben gevolgd het minst vaak zeggen achteraf gezien opnieuw te kiezen voor dezelfde vervolgopleiding aan dezelfde instelling. Voor havisten varieert het aandeel schoolverlaters dat achteraf dezelfde vervolgopleiding aan dezelfde instelling zou kiezen van $72 \%$ voor schoolverlaters met het profiel economie en maatschappij tot $78 \%$ voor schoolverlaters met het profiel natuur en gezondheid. Bij VWO'ers die doorstromen naar het $\mathrm{HBO}$ van $78 \%$ voor schoolverlaters met het profiel economie en maatschappij tot $90 \%$ voor schoolverlaters met het profiel natuur en techniek. En bij schoolverlaters van het VWO die doorstromen naar het WO zijn de verschillen tussen de profielen verwaarloosbaar klein, deze varieert van $82 \%$ tot $84 \%$.

Verder is vrij opvallend dat relatief veel schoolverlaters van het HAVO met het profiel natuur en techniek die verder gaan in het HBO zeggen achteraf gezien liever een 
andere vervolgopleiding te kiezen, terwijl dit aandeel voor VWO'ers met het profiel natuur en techniek die verder gaan in het $\mathrm{HBO}$ zeer klein is. Waarschijnlijk komt dit omdat de overgang van het profiel natuur en techniek naar de vervolgopleiding in het HBO voor havisten minder eenvoudig verloopt dan voor VWO'ers

Tabel 5.2

aandeel HAVO/VWO-schoolverlaters dat de vervolgopleiding achteraf gezien opnieuw zou kiezen, naar profiel

\begin{tabular}{|c|c|c|c|c|}
\hline & $\begin{array}{c}\text { Ja, zelfde } \\
\text { vervolg- } \\
\text { opleiding aan } \\
\text { zelfde instelling }\end{array}$ & $\begin{array}{l}\text { Ja, zelfde } \\
\text { vervolg- } \\
\text { opleiding aan } \\
\text { andere } \\
\text { instelling }\end{array}$ & $\begin{array}{l}\text { Nee, andere } \\
\text { vervolg- } \\
\text { opleiding }\end{array}$ & $\begin{array}{c}\text { Nee, geen } \\
\text { vervolg- } \\
\text { opleiding }\end{array}$ \\
\hline \multicolumn{5}{|l|}{ HAVO nieuwe stijl - HBO } \\
\hline cultuur en maatschappij & 77 & 7 & 16 & 0 \\
\hline economie en maatschappij & 72 & 9 & 18 & 1 \\
\hline natuur en gezondheid & 78 & 9 & 13 & 1 \\
\hline natuur en techniek & 73 & 6 & 19 & 2 \\
\hline \multicolumn{5}{|l|}{ VWO nieuwe stijl - HBO } \\
\hline cultuur en maatschappij & 81 & 7 & 11 & 1 \\
\hline economie en maatschappij & 78 & 8 & 13 & 0 \\
\hline natuur en gezondheid & 86 & 3 & 11 & 1 \\
\hline natuur en techniek & 90 & 6 & 4 & 0 \\
\hline \multicolumn{5}{|l|}{ VWO nieuwe stijl - WO } \\
\hline cultuur en maatschappij & 82 & 4 & 14 & 1 \\
\hline economie en maatschappij & 82 & 4 & 14 & 0 \\
\hline natuur en gezondheid & 84 & 3 & 13 & 0 \\
\hline natuur en techniek & 83 & 5 & 12 & 0 \\
\hline
\end{tabular}

De keuze van de vervolgopleiding achteraf gezien is vervolgens multivariaat geanalyseerd. Tabel 5.3 laat de resultaten van deze analyse zien. Weergegeven is de kans dat schoolverlaters achteraf gezien opnieuw voor dezelfde vervolgopleiding zouden kiezen aan dezelfde of een andere instelling. Overigens kan het zijn dat de resultaten van de multivariate analyse verschillen van die van de kruistabellen. Dit komt omdat in een multivariate analyse rekening wordt gehouden met meerdere kenmerken van schoolverlaters.

In tabel 5.3 zien we alléén bij havisten die doorstromen naar het HBO en bij VWO'ers die verder gaan studeren in het WO significante effecten. Daarbij is vooral de sector van de vervolgopleiding van belang. Vooral havisten die doorstromen naar een HBOopleiding in de sector onderwijs, techniek, gedrag en maatschappij geven aan achteraf gezien opnieuw voor dezelfde vervolgopleiding te kiezen. Daarnaast geldt dat mannelijke havisten minder vaak dan vrouwelijke havisten opnieuw voor dezelfde vervolgopleiding in het HBO zouden kiezen. Verder blijkt dat havisten minder vaak zeggen dezelfde vervolgopleiding te kiezen naarmate ze langer over de opleiding in het HAVO hebben gedaan. 
Tabel 5.3

Multivariate analyse van de kans dat HAVO/VWO-schoolverlaters de vervolgopleiding achteraf gezien opnieuw zouden kiezen*

\begin{tabular}{|c|c|c|c|}
\hline & $\begin{array}{l}\text { HAVO nieuwe } \\
\text { stijl - HBO }\end{array}$ & $\begin{array}{l}\text { VWO nieuwe } \\
\text { stijl - HBO }\end{array}$ & $\begin{array}{l}\text { VWO nieuwe } \\
\text { stijl - WO }\end{array}$ \\
\hline \multicolumn{4}{|l|}{ Geslacht } \\
\hline vrouw & referentie & referentie & referentie \\
\hline man & - & 0 & 0 \\
\hline \multicolumn{4}{|l|}{ Profiel } \\
\hline cultuur en maatschappij & referentie & referentie & referentie \\
\hline economie en maatschappij & 0 & 0 & 0 \\
\hline natuur en gezondheid & 0 & 0 & 0 \\
\hline natuur en techniek & 0 & 0 & 0 \\
\hline Profieloverstap & 0 & 0 & - \\
\hline Gemiddeld examencijfer & 0 & 0 & + \\
\hline \multicolumn{4}{|l|}{ Hoogst behaalde vooropleiding } \\
\hline geen & referentie & referentie & referentie \\
\hline mavo & 0 & 0 & 0 \\
\hline havo & 0 & 0 & 0 \\
\hline anders & 0 & 0 & 0 \\
\hline Duur havo/vwo opleiding & - & 0 & 0 \\
\hline \multicolumn{4}{|l|}{ Sector vervolgopleiding } \\
\hline landbouw & 0 & 0 & 0 \\
\hline onderwijs & + & 0 & \# \\
\hline techniek & + & 0 & 0 \\
\hline economie & referentie & referentie & referentie \\
\hline gezondheidszorg & 0 & 0 & + \\
\hline gedrag en maatschappij & + & 0 & + \\
\hline taal en cultuur & 0 & 0 & 0 \\
\hline recht en openbare orde & \# & \# & 0 \\
\hline natuurwetenschappen & \# & \# & 0 \\
\hline
\end{tabular}

* betreft de kans dat schoolverlaters achteraf gezien dezelfde vervolgopleiding zouden kiezen, aan dezelfde of een andere instelling

- = negatief significant effect op 5\%-niveau

$0=$ geen significant effect op $5 \%$-niveau

$+=$ positief significant effect op $5 \%$-niveau

Van de schoolverlaters van het VWO die verder studeren in het WO zeggen met name degenen die doorstromen naar een WO-opleiding in de sector gezondheidszorg en gedrag en maatschappij dat ze achteraf gezien opnieuw zouden kiezen voor dezelfde vervolgopleiding. Ook een profieloverstap blijkt hier van invloed te zijn. Schoolverlaters van het VWO die ooit een profieloverstap hebben gemaakt, zeggen minder vaak dat ze opnieuw voor dezelfde vervolgopleiding zouden kiezen. Bovendien geldt dat VWO'ers minder vaak aangeven opnieuw voor dezelfde vervolgopleiding te kiezen wanneer ze het profiel natuur en techniek hebben gevolgd. Tot slot komt hier naar voren dat degenen met een gemiddeld hoog eindexamencijfer vaker zeggen dezelfde vervolgopleiding te kiezen dan degenen met een lager eindexamencijfer. 



\section{Uitval in de vervolgopleiding}

Eén van de voornaamste redenen om de tweede fase in te voeren in het voortgezet onderwijs was het probleem van de aansluiting tussen voortgezet en hoger onderwijs. Dit kwam onder meer tot uiting in het aantal studenten dat de vervolgopleiding in het hoger onderwijs voortijdig beëindigde. In dit hoofdstuk wordt bekeken welk deel van de schoolverlaters oude en nieuwe stijl aangeeft de vervolgopleiding nog steeds te volgen of voortijdig te hebben verlaten. Daarna wordt ingegaan op de redenen van schoolverlaters voor het voortijdig verlaten van de vervolgopleiding. Tot slot wordt bekeken of schoolverlaters die de vervolgopleiding voortijdig hebben verlaten in het onderwijs zijn gebleven en verder zijn gegaan in een andere vervolgopleiding.

Aan de schoolverlaters is gevraagd of ze na de HAVO- of VWO-opleiding een vervolgopleiding zijn gaan doen. Daarna is gevraagd of ze deze vervolgopleiding nog steeds volgen. In tabel 6.1 is het aandeel schoolverlaters weergegeven dat zegt de vervolgopleiding nog steeds te volgen en het aandeel schoolverlaters dat zegt de vervolgopleiding voortijdig te hebben verlaten. Zoals in de inleiding is vermeld, zijn deze cijfers gebaseerd op de situatie ongeveer anderhalf jaar na het verlaten van het HAVO of VWO. Het merendeel van de schoolverlaters zegt de vervolgopleiding nog steeds te volgen. Daarbij geven schoolverlaters na de invoering van de tweede fase iets vaker dan voorheen aan de vervolgopleiding nog steeds te volgen. In figuur 6.1 is per meetjaar de uitval onder schoolverlaters van het HAVO en VWO vermeld. Deze figuur laat zien dat het aandeel HAVO/VWO-schoolverlaters dat zegt de vervolgopleiding in het $\mathrm{HBO}$ of WO voortijdig te hebben verlaten met name vanaf 2003 afneemt. De vraag is of deze trend zich voortzet. Overigens laten ook cijfers van het CBS over de uitval in het eerste en tweede jaar van de opleiding in het hoger onderwijs zien dat na de invoering van de tweede fase de uitval iets is afgenomen.

Tabel 6.1

Aandeel HAVO/VWO-schoolverlaters oude en nieuwe stijl dat de vervolgopleiding nog steeds volgt of heeft verlaten

\begin{tabular}{lcc}
\hline & $\begin{array}{c}\text { Ja, volg vervolgopleiding } \\
\text { nog steeds }\end{array}$ & $\begin{array}{c}\text { Nee, voortijdig } \\
\text { vervolgopleiding verlaten }\end{array}$ \\
\hline HAVO oude stijl - HBO & 81 & 19 \\
VWO oude stijl - HBO & 87 & 13 \\
VWO oude stijl - WO & 86 & 14 \\
& & 16 \\
HAVO nieuwe stijl - HBO & 84 & 11 \\
VWO nieuwe stijl - HBO & 89 & 15 \\
VWO nieuwe stijl - WO & 85 &
\end{tabular}


Figuur 6.1

Aandeel HAVO/VWO-schoolverlaters oude en nieuwe stijl dat de vervolgopleiding heeft verlaten per meetjaar

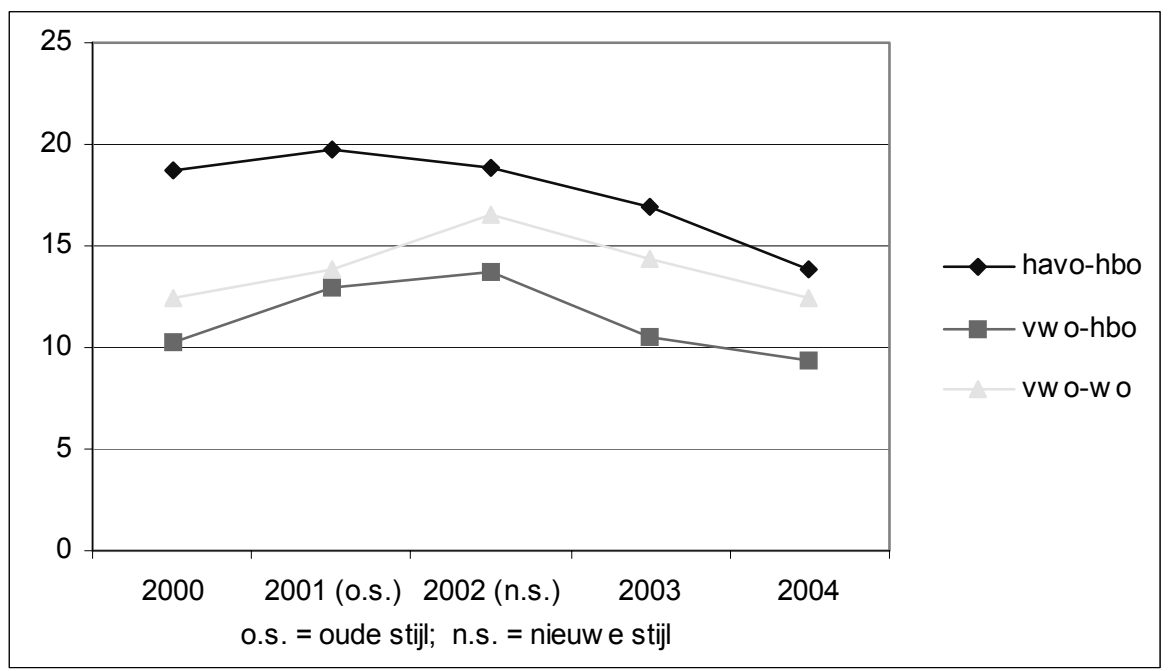

Tabel 6.2 laat voor de verschillende studieprofielen zien in hoeverre schoolverlaters aangeven de vervolgopleiding nog steeds te volgen. Voor havisten die verder gaan in het HBO geldt dat schoolverlaters met het profiel natuur en techniek het minst vaak en schoolverlaters met het profiel natuur en gezondheid het vaakst zeggen de vervolgopleiding nog steeds te volgen. Bij VWO'ers die doorstromen naar het HBO geldt juist dat degenen met het profiel natuur en techniek het vaakst zeggen de vervolgopleiding nog steeds te volgen. Eerder hebben we voor het profiel natuur en techniek al gezien dat de aansluiting met het hoger onderwijs volgens schoolverlaters beter verloopt voor VWO'ers die verder gaan in het HBO dan voor havisten die verder gaan in het HBO. Verder blijkt voor VWO'ers die verder gaan in het $\mathrm{HBO}$ en WO dat de uitval het hoogst is voor schoolverlaters die het profiel cultuur en maatschappij hebben gevolgd.

Vervolgens hebben we onderzocht welke factoren van invloed zijn op het voortijdig beëindigen van de vervolgopleiding. Hiervoor hebben we een multivariate analyse uitgevoerd van de kans dat HAVO- en VWO-schoolverlaters aangeven de vervolgopleiding nog steeds te volgen relatief ten opzichte van de kans dat HAVOen VWO-schoolverlaters zeggen de vervolgopleiding voortijdig te hebben verlaten. In tabel 6.3 zijn de resultaten hiervan weergegeven. Bij havisten die verder studeren in het HBO heeft de duur van de HAVO-opleiding en de sector van de vervolgopleiding een significante invloed. Naarmate havisten langer hebben gedaan over de HAVOopleiding is de kans kleiner dat ze aangeven de vervolgopleiding nog steeds te volgen. Daarnaast blijkt dat relatief veel havisten die verder gaan in een vervolgopleiding in de sector $\mathrm{HBO}$ onderwijs de opleiding nog steeds volgen. 
Tabel 6.2

Aandeel HAVO/VWO-schoolverlaters oude en nieuwe stijl dat de vervolgopleiding nog steeds volgt of heeft verlaten, naar profiel

Ja, volg vervolgopleiding Nee, voortijdig vervolgopleiding nog steeds verlaten

HAVO nieuwe stijl - HBO

cultuur en maatschappij

economie en maatschappij

natuur en gezondheid

natuur en techniek

$\begin{array}{ll}84 & 16 \\ 83 & 17 \\ 87 & 13 \\ 81 & 19\end{array}$

VWO nieuwe stijl - HBO

cultuur en maatschappi

economie en maatschappij

natuur en gezondheid

natuur en techniek

$\begin{array}{lc}88 & 12 \\ 89 & 11 \\ 91 & 9 \\ 93 & 7\end{array}$

VWO nieuwe stijl - WO

cultuur en maatschappij

economie en maatschappij

natuur en gezondheid

natuur en techniek

$\begin{array}{ll}84 & 16 \\ 86 & 14 \\ 86 & 14 \\ 88 & 12\end{array}$

Bij VWO'ers die verder gaan in het HBO zien we geen significante effecten van de variabelen die zijn opgenomen in de analyse. Daarentegen vinden we bij VWO'ers die doorstromen naar het WO dat een profieloverstap, het gemiddeld examencijfer en de sector van de vervolgopleiding een rol spelen bij de kans de vervolgopleiding nog steeds te volgen. Het blijkt dat degenen die een profieloverstap hebben gemaakt minder vaak aangeven de vervolgopleiding nog steeds te volgen dan degenen die geen profieloverstap hebben gemaakt. Verder geldt dat VWO'ers die een hoog gemiddeld examencijfer hebben behaald vaker zeggen de opleiding nog steeds te volgen dan VWO'ers die een lager examencijfer hebben behaald. Bovendien komt naar voren dat met name VWO'ers die hebben gekozen voor een WOvervolgopleiding in de sector gezondheidszorg en gedrag en maatschappij nog steeds deze vervolgopleiding volgen.

In tabel 6.4 wordt vervolgens ingegaan op de redenen die schoolverlaters geven om de vervolgopleiding voortijdig te verlaten. 'Achteraf gezien liever een andere opleiding volgen' en 'onvoldoende motivatie' worden het vaakst genoemd door schoolverlaters als reden voor de uitval in de vervolgopleiding. Opvallend daarbij is dat HAVO- en VWO-schoolverlaters die verder gaan in het $\mathrm{HBO}$ na de invoering van de tweede fase de reden 'onvoldoende motivatie' minder vaak noemen dan voor de invoering. Hetzelfde zien we bij de redenen 'de lessen waren niet interessant' en 'de opleiding was te moeilijk'. Dit duidt er op dat havisten en VWO'ers die doorstromen naar het HBO vaker zeggen gemotiveerd te zijn in de vervolgopleiding en deze vervolgopleiding minder vaak te moeilijk vinden sinds de invoering van de tweede fase. 
Tabel 6.3

Multivariate analyse van de kans dat HAVO/VWO-schoolverlaters de vervolgopleiding nog steeds volgen*

\begin{tabular}{|c|c|c|c|}
\hline & $\begin{array}{l}\text { HAVO nieuwe } \\
\text { stijl - HBO }\end{array}$ & $\begin{array}{l}\text { VWO nieuwe } \\
\text { stijl - HBO }\end{array}$ & $\begin{array}{l}\text { VWO nieuwe } \\
\text { stijl - WO }\end{array}$ \\
\hline \multicolumn{4}{|l|}{ Geslacht } \\
\hline vrouw & referentie & referentie & referentie \\
\hline man & 0 & 0 & 0 \\
\hline \multicolumn{4}{|l|}{ Profiel } \\
\hline cultuur en maatschappij & referentie & referentie & referentie \\
\hline economie en maatschappij & 0 & 0 & 0 \\
\hline natuur en gezondheid & 0 & 0 & 0 \\
\hline natuur en techniek & 0 & 0 & 0 \\
\hline Profieloverstap & 0 & 0 & - \\
\hline Gemiddeld examencijfer & 0 & 0 & + \\
\hline \multicolumn{4}{|l|}{ Hoogst behaalde vooropleiding } \\
\hline geen & referentie & referentie & referentie \\
\hline mavo & 0 & 0 & 0 \\
\hline havo & 0 & 0 & 0 \\
\hline anders & 0 & 0 & 0 \\
\hline Duur havo/vwo opleiding & - & 0 & 0 \\
\hline \multicolumn{4}{|l|}{ Sector vervolgopleiding } \\
\hline landbouw & 0 & 0 & 0 \\
\hline onderwijs & + & 0 & \# \\
\hline techniek & 0 & 0 & 0 \\
\hline economie & referentie & referentie & referentie \\
\hline gezondheidszorg & 0 & 0 & + \\
\hline gedrag en maatschappij & 0 & 0 & + \\
\hline taal en cultuur & 0 & 0 & 0 \\
\hline recht en openbare orde & \# & \# & 0 \\
\hline natuurwetenschappen & \# & \# & 0 \\
\hline
\end{tabular}

* relatief ten opzichte van schoolverlaters die de vervolgopleiding voortijdig hebben verlaten

- = negatief significant effect op 5\%-niveau

$0=$ geen significant effect op 5\%-niveau

$+=$ positief significant effect op $5 \%$-niveau

Tabel 6.4

Reden van HAVO/VWO-schoolverlaters oude en nieuwe stijl voor het voortijdig verlaten van de vervolgopleiding

\begin{tabular}{lcccccc}
\hline & $\begin{array}{c}\text { Onvol- } \\
\text { doende } \\
\text { gemoti- } \\
\text { veerd }\end{array}$ & $\begin{array}{c}\text { Lessen } \\
\text { niet } \\
\text { interes- } \\
\text { sant }\end{array}$ & $\begin{array}{c}\text { De } \\
\text { opleiding } \\
\text { was te } \\
\text { moeilijk }\end{array}$ & $\begin{array}{c}\text { Achteraf } \\
\text { andere } \\
\text { opleiding } \\
\text { volgen }\end{array}$ & $\begin{array}{c}\text { Wil liever } \\
\text { gaan } \\
\text { werken }\end{array}$ & Anders \\
\hline Totaal & & & & & & \\
HAVO oude stijl - HBO & 39 & 36 & 23 & 48 & 6 & 40 \\
VWO oude stijl - HBO & 40 & 39 & 14 & 48 & 6 & 51 \\
VWO oude stijl - WO & 43 & 33 & 23 & 45 & 2 & 39 \\
HAVO nieuwe stijl - HBO & 31 & 28 & 18 & 49 & 4 & 39 \\
VWO nieuwe stijl - HBO & 29 & 30 & 5 & 43 & 2 & 57 \\
VWO nieuwe stijl - WO & 42 & 31 & 24 & 48 & 1 & 32 \\
\hline *merdere antwOF & & & & & & \\
\hline
\end{tabular}

* meerdere antwoorden mogelijk 
Tabel 6.5

Reden van HAVO/VWO-schoolverlaters voor het voortijdig verlaten van de vervolgopleiding, naar profiel $^{*}$

\begin{tabular}{|c|c|c|c|c|c|c|}
\hline & $\begin{array}{l}\text { Onvol- } \\
\text { doende } \\
\text { gemoti- } \\
\text { veerd }\end{array}$ & $\begin{array}{c}\text { Lessen } \\
\text { niet } \\
\text { interes- } \\
\text { sant }\end{array}$ & $\begin{array}{c}\text { De } \\
\text { opleiding } \\
\text { was te } \\
\text { moeilijk }\end{array}$ & $\begin{array}{l}\text { Achteraf } \\
\text { andere } \\
\text { opleiding } \\
\text { volgen }\end{array}$ & $\begin{array}{l}\text { Wil liever } \\
\text { gaan } \\
\text { werken }\end{array}$ & Anders \\
\hline \multicolumn{7}{|l|}{ HAVO nieuwe stijl - HBO } \\
\hline cultuur en maatschappij & 24 & 22 & 10 & 48 & 2 & 49 \\
\hline economie en maatschappij & 33 & 33 & 18 & 56 & 6 & 30 \\
\hline natuur en gezondheid & 37 & 28 & 20 & 39 & 1 & 44 \\
\hline natuur en techniek & 33 & 30 & 28 & 41 & 3 & 37 \\
\hline \multicolumn{7}{|l|}{ VWO nieuwe stijl - HBO } \\
\hline cultuur en maatschappij & 19 & 26 & 4 & 50 & 0 & 54 \\
\hline economie en maatschappij & 31 & 29 & 2 & 40 & 0 & 57 \\
\hline natuur en gezondheid & 30 & 37 & 5 & 50 & 11 & 70 \\
\hline natuur en techniek & $\mathrm{x}$ & $x$ & $x$ & $x$ & $x$ & $x$ \\
\hline \multicolumn{7}{|l|}{ VWO nieuwe stijl - WO } \\
\hline cultuur en maatschappij & 40 & 25 & 14 & 47 & 3 & 42 \\
\hline economie en maatschappij & 47 & 39 & 27 & 46 & 0 & 22 \\
\hline natuur en gezondheid & 40 & 30 & 21 & 52 & 2 & 35 \\
\hline natuur en techniek & 43 & 28 & 33 & 47 & 1 & 36 \\
\hline
\end{tabular}

* meerdere antwoorden mogelijk

$x=$ te weinig waarnemingen

De redenen voor het voortijdig verlaten van de vervolgopleiding verschillen voor schoolverlaters naar studieprofiel (zie tabel 6.5). Over het algemeen zien we dat schoolverlaters met het profiel cultuur en maatschappij minder vaak 'onvoldoende motivatie', 'oninteressante lessen' of 'de opleiding was te moeilijk' noemen als reden om te stoppen met de vervolgopleiding dan schoolverlaters met een ander studieprofiel. Daarnaast blijkt dat van de havisten degenen met het profiel economie en maatschappij het vaakst zeggen dat ze achteraf liever een andere opleiding volgen. Havisten met het profiel natuur en techniek die verder gaan studeren in het HBO zeggen vaker dan havisten met een ander profiel dat de opleiding te moeilijk was. Hetzelfde zien we bij VWO'ers met het studieprofiel natuur en techniek die verder studeren in het WO.

In de tabellen $5 a$ tot en met $5 c$ van de bijlage zijn de resultaten vermeld van de multivariate analyse van de redenen voor het voortijdig verlaten van de vervolgopleiding. In deze rapportage wordt hier niet nader op ingegaan.

Tot slot van dit hoofdstuk wordt ingegaan op de vraag of degenen die voortijdig de vervolgopleiding hebben verlaten van studie zijn gewisseld. Dit aandeel studiewisselaars hebben we bepaald op basis van het aandeel schoolverlaters dat de vervolgopleiding voortijdig heeft verlaten en zegt dat de belangrijkste bezigheid op dit moment scholier/student is. De overigen geven aan dat ze naar de arbeidsmarkt zijn gegaan, werken combineren met leren of zeggen nog een andere bestemming te 
hebben (huishouden, reizen et. cetera). In tabel 6.6 is het aandeel uitvallers weergegeven dat zegt opnieuw voor een vervolgopleiding te hebben gekozen, voor schoolverlaters oude en nieuwe stijl en voor verschillende profielen.

Tabel 6.6

Aandeel uitvallers dat opnieuw een vervolgopleiding heeft gekozen

\begin{tabular}{|c|c|c|c|c|c|}
\hline & totaal & $\begin{array}{c}\text { cultuur en } \\
\text { maatschappij }\end{array}$ & $\begin{array}{l}\text { economie en } \\
\text { maatschappij }\end{array}$ & $\begin{array}{l}\text { natuur en } \\
\text { gezondheid }\end{array}$ & $\begin{array}{c}\text { natuur en } \\
\text { techniek }\end{array}$ \\
\hline HAVO oude stijl - HBO & 72 & n.v.t & n.v.t & n.v.t & n.v.t \\
\hline VWO oude stijl - HBO & 87 & n.v.t & n.v.t & n.v.t & n.v.t \\
\hline VWO oude stijl - WO & 83 & n.v.t & n.v.t & n.v.t & n.v.t \\
\hline HAVO nieuwe stijl - HBO & 78 & 78 & 78 & 76 & 80 \\
\hline VWO nieuwe stijl - HBO & 65 & 57 & 65 & 74 & $x$ \\
\hline VWO nieuwe stijl - WO & 90 & 85 & 90 & 91 & 93 \\
\hline
\end{tabular}

n.v.t. = niet van toepassing

$\mathrm{x}=$ te weinig waarnemingen

Opvallend in tabel 6.6 is dat VWO'ers die uitvallen in het $\mathrm{HBO}$ tegenwoordig minder vaak dan voorheen van studie wisselen. Nu geeft 'slechts' $65 \%$ van de VWO'ers die uitvallen in het $\mathrm{HBO}$ aan opnieuw te hebben gekozen voor een vervolgopleiding, terwijl dit aandeel vroeger $87 \%$ bedroeg. Daarbij zien we dat van de VWO'ers nieuwe stijl die uitvallen in het HBO degenen met het profiel cultuur en maatschappij het minst vaak zeggen opnieuw te kiezen voor een vervolgopleiding (57\%). Havisten die de opleiding in het HBO voortijdig verlaten en VWO'ers die de opleiding in het WO voortijdig verlaten, kiezen daarentegen na de invoering van de tweede fase vaker opnieuw voor een vervolgopleiding dan ervoor. Overigens blijkt uit hier niet gepresenteerde cijfers dat het merendeel van de uitvallers nieuwe stijl die niet opnieuw kiezen voor een vervolgopleiding de arbeidsmarkt betreden. 


\section{Keuze van het vakkenpakket/profiel}

In dit hoofdstuk staat het vakkenpakket/profiel dat havisten en VWO'ers hebben gevolgd centraal. Eerst wordt bekeken in hoeverre schoolverlaters van het HAVO en VWO tevreden zijn over de hulp bij het gekozen vakkenpakket/profiel. Daarna wordt ingegaan op de vraag of schoolverlaters achteraf gezien opnieuw zouden kiezen voor het gevolgde vakkenpakket/profiel. Vervolgens komen aan het einde van dit hoofdstuk de redenen aan bod om niet opnieuw te kiezen voor het gevolgde vakkenpakket/profiel.

Aan schoolverlaters is gevraagd hoe tevreden ze zijn over de hulp die ze hebben gehad bij de keuze van het vakkenpakket/profiel. Dit is gemeten op een vijfpuntschaal die loopt van zeer ontevreden tot zeer tevreden. In tabel 7.1 is het aandeel schoolverlaters vermeld dat (zeer) tevreden is over de hulp bij de keuze van het vakkenpakket/profiel (antwoordcategorieën 4 en 5). Over het algemeen is het aandeel schoolverlaters dat (zeer) tevreden is over de hulp bij de keuze van het vakkenpakket/profiel niet bijzonder groot. Om en nabij de helft van de schoolverlaters zegt hierover (zeer) tevreden te zijn. Bij havisten oude stijl die doorstromen naar het $\mathrm{HBO}$ is dit percentage, met $27 \%$, opvallend laag. Voor havisten nieuwe stijl die doorstromen naar het HBO ligt dit aandeel met $47 \%$ echter hoger. Met andere woorden: havisten die doorstromen naar het $\mathrm{HBO}$ zijn nu meer tevreden over de hulp bij de keuze van het vakkenpakket/profiel dan voorheen. Bij VWO'ers zien we dit minder sterk. Alléén voor VWO'ers die verder studeren in het WO is het aandeel schoolverlaters dat (zeer) tevreden is over de hulp bij de keuze van het vakkenpakket/profiel iets toegenomen van $49 \%$ voor de invoering van de tweede fase naar $53 \%$ na de invoering. Overigens blijkt voor schoolverlaters nieuwe stijl dat degenen met het studieprofiel economie en maatschappij doorgaans het minst vaakst zeggen (zeer) tevreden te zijn over de hulp bij de keuze van het vakkenpakket/profiel.

Tabel 7.1

Aandeel HAVO/VWO-schoolverlaters oude en nieuwe stijl dat (zeer) tevreden is over de hulp bij de keuze voor het vakkenpakket/profiel

\begin{tabular}{lccccc}
\hline & totaal & $\begin{array}{c}\text { cultuur en } \\
\text { maatschappij maatschappij }\end{array}$ & $\begin{array}{c}\text { natuur en } \\
\text { gezondheid }\end{array}$ & $\begin{array}{c}\text { natuur en } \\
\text { techniek }\end{array}$ \\
\hline HAVO oude stijl - HBO & 27 & n.v.t & n.v.t & n.v.t & n.v.t \\
VWO oude stijl - HBO & 46 & n.v.t & n.v.t & n.v.t & n.v.t \\
VWO oude stijl - WO & 49 & n.v.t & n.v.t & n.v.t & n.v.t \\
HAVO nieuwe stijl - HBO & 47 & 49 & 44 & 49 & 48 \\
VWO nieuwe stijl - HBO & 46 & 51 & 41 & 47 & 45 \\
VWO nieuwe stijl - WO & 53 & 51 & 48 & 57 & 55 \\
& & & & & \\
\hline
\end{tabular}

Antwoord 4 of 5 op een schaal van 1 (zeer ontevreden) t/m 5 (zeer tevreden)

n.v.t. = niet van toepassing 
Vervolgens is aan de schoolverlaters gevraagd of ze achteraf gezien opnieuw voor hetzelfde vakkenpakket/profiel zouden kiezen. Hieruit blijkt dat schoolverlaters nu vaker dan voorheen aangeven opnieuw te kiezen voor het gevolgde vakkenpakket/profiel (zie tabel 7.2). Ook hier is het verschil tussen schoolverlaters oude en nieuwe stijl het grootst bij havisten die verder gaan in het HBO. Waar voorheen $62 \%$ van de havisten aangaf opnieuw te kiezen voor het gevolgde vakkenpakket/profiel, is dit aandeel nu 85\%. Verder zien we in tabel 7.2 dat schoolverlaters met een uiteenlopend profiel maar weinig verschillen in de keuze voor het vakkenpakket/ profiel achteraf gezien.

Tabel 7.2

Aandeel HAVO/VWO-schoolverlaters oude en nieuwe stijl dat achteraf gezien het gevolgde vakkenpakket/profiel opnieuw zou kiezen

\begin{tabular}{lccccc}
\hline & totaal & $\begin{array}{c}\text { cultuur en } \\
\text { maatschappij }\end{array}$ & & economie en \\
matschappij & $\begin{array}{c}\text { natuur en } \\
\text { gezondheid }\end{array}$ & $\begin{array}{c}\text { natuur en } \\
\text { techniek }\end{array}$ \\
\hline HAVO oude stijl - HBO & 62 & n.v.t & n.v.t & n.v.t & n.v.t \\
VWO oude stijl - HBO & 79 & n.v.t & n.v.t & n.v.t & n.v.t \\
VWO oude stijl - WO & 81 & n.v.t & n.v.t & n.v.t & n.v.t \\
HAVO nieuwe stijl - HBO & 85 & 86 & 84 & 85 & 87 \\
VWO nieuwe stijl - HBO & 87 & 86 & 87 & 88 & 87 \\
VWO nieuwe stijl - WO & 89 & 88 & 88 & 90 & 90 \\
\hline
\end{tabular}

n.v.t. = niet van toepassing

Tabel 7.3 laat de resultaten zien van de multivariate analyse van de kans dat schoolverlaters nieuwe stijl achteraf gezien het gevolgde profiel opnieuw zouden kiezen. Uit deze tabel komt naar voren dat verschillende factoren een rol spelen bij de keuze van het gevolgde profiel achteraf gezien. Vooral havisten met het profiel natuur en techniek zeggen achteraf gezien opnieuw te zullen kiezen voor het gevolgde profiel. Daarnaast geldt dat havisten met een hoog gemiddeld eindexamencijfer vaker zeggen achteraf gezien opnieuw voor het gevolgde profiel dan havisten met een lager cijfer. Verder komt naar voren dat havisten minder vaak zeggen opnieuw het gevolgde profiel te kiezen naarmate ze langer over de HAVOopleiding hebben gedaan. Bovendien zien we dat relatief veel havisten die kiezen voor een HBO-opleiding in de sector onderwijs, gezondheidszorg en gedrag en maatschappij aangeven achteraf gezien opnieuw voor het gevolgde profiel te kiezen.

Bij VWO'ers die verder gaan in het WO spelen geslacht, profiel, hoogst behaalde vooropleiding en sector van de vervolgopleiding een rol bij de keuze van het gevolgde profiel achteraf gezien. Ten eerste blijkt hier dat mannen minder vaak dan vrouwen zeggen opnieuw te kiezen voor het profiel. Ten tweede geven vooral VWO'ers met het profiel natuur en gezondheid minder vaak aan achteraf gezien opnieuw voor het gevolgde profiel te kiezen. Ten derde zouden VWO'ers met een andere vooropleiding dan het HAVO minder vaak opnieuw kiezen voor hetzelfde profiel. Ten vierde zeggen relatief veel VWO'ers die doorgaan in een WO-opleiding in de sector gezondheidszorg en relatief weinig VWO'ers die doorgaan in een WO- 
opleiding in de sector gedrag en maatschappij opnieuw voor het gevolgde profiel te kiezen.

Tabel 7.3

Multivariate analyse van de kans dat HAVO/VWO-schoolverlaters achteraf gezien het gevolgde profiel opnieuw zouden kiezen

\begin{tabular}{|c|c|c|c|}
\hline & $\begin{array}{l}\text { HAVO nieuwe } \\
\text { stijl - HBO }\end{array}$ & $\begin{array}{l}\text { VWO nieuwe } \\
\text { stijl - HBO }\end{array}$ & $\begin{array}{l}\text { VWO nieuwe } \\
\text { stijl - WO }\end{array}$ \\
\hline \multicolumn{4}{|l|}{ Geslacht } \\
\hline vrouw & referentie & referentie & referentie \\
\hline man & 0 & 0 & - \\
\hline \multicolumn{4}{|l|}{ Profiel } \\
\hline cultuur en maatschappij & 0 & 0 & 0 \\
\hline economie en maatschappij & referentie & referentie & referentie \\
\hline natuur en gezondheid & 0 & 0 & - \\
\hline natuur en techniek & + & 0 & 0 \\
\hline Profieloverstap & 0 & 0 & 0 \\
\hline Gemiddeld examencijfer & + & 0 & 0 \\
\hline \multicolumn{4}{|l|}{ Hoogst behaalde vooropleiding } \\
\hline geen & referentie & referentie & referentie \\
\hline mavo & 0 & 0 & 0 \\
\hline havo & 0 & 0 & 0 \\
\hline anders & 0 & 0 & - \\
\hline \multirow{2}{*}{\multicolumn{4}{|c|}{ Sector vervolgopleiding }} \\
\hline & & & \\
\hline landbouw & 0 & 0 & 0 \\
\hline onderwijs & - & 0 & \# \\
\hline techniek & 0 & 0 & 0 \\
\hline economie & referentie & referentie & referentie \\
\hline gezondheidszorg & - & 0 & + \\
\hline gedrag en maatschappij & - & 0 & - \\
\hline taal en cultuur & 0 & 0 & 0 \\
\hline recht en openbare orde & \# & \# & 0 \\
\hline natuurwetenschappen & \# & \# & 0 \\
\hline
\end{tabular}

Tabel 7.4 laat de redenen zien die schoolverlaters nieuwe stijl geven om achteraf gezien niet opnieuw te kiezen voor het gevolgde profiel. Schoolverlaters geven vaak aan dat het profiel onvoldoende aansluit bij de vervolgopleiding als reden om niet opnieuw het gevolgde profiel te kiezen. Dit aandeel varieert van 36\% voor VWO'ers die verder gaan in het WO tot $56 \%$ voor VWO'ers die doorstromen naar het HBO. Bij havisten die doorstromen naar het $\mathrm{HBO}$ zeggen relatief weinig schoolverlaters met het profiel natuur en techniek dat het gevolgde profiel onvoldoende aansluit bij de vervolgopleiding. Daarnaast zeggen havisten met het profiel economie en maatschappij vaker dan havisten met een ander profiel dat het gevolgde profiel niet goed aansluit bij de talenten. Havisten met het profiel natuur en gezondheid en natuur en techniek geven duidelijk vaker aan dan havisten met het profiel cultuur en maatschappij en economie en maatschappij niet opnieuw te kiezen voor het gevolgde profiel omdat deze te moeilijk is gebleken. 
Tabel 7.4

Redenen voor HAVO/VWO-schoolverlaters nieuwe stijl om niet opnieuw te kiezen voor het gevolgde profiel, naar profiel $^{\star}$

\begin{tabular}{|c|c|c|c|c|c|c|}
\hline & \multicolumn{6}{|c|}{ Het gevolgde profiel: } \\
\hline & $\begin{array}{c}\text { Niet } \\
\text { interes- } \\
\text { sant } \\
\text { genoeg }\end{array}$ & $\begin{array}{c}\text { Sluit } \\
\text { onvol- } \\
\text { doende } \\
\text { aan bij } \\
\text { vervolg- } \\
\text { opleiding }\end{array}$ & $\begin{array}{l}\text { Te moeilijk } \\
\text { gebleken }\end{array}$ & $\begin{array}{l}\text { Kun je } \\
\text { weinig } \\
\text { kanten } \\
\text { mee op }\end{array}$ & $\begin{array}{l}\text { Sluit niet } \\
\text { aan bij } \\
\text { mijn } \\
\text { talenten }\end{array}$ & Anders \\
\hline \multicolumn{7}{|l|}{ HAVO nieuwe stijl - HBO } \\
\hline $\begin{array}{l}\text { cultuur en maatschappij } \\
\text { economie en maatschappij }\end{array}$ & $\begin{array}{l}17 \\
18\end{array}$ & $\begin{array}{l}49 \\
46\end{array}$ & $\begin{array}{l}2 \\
7\end{array}$ & $\begin{array}{l}19 \\
10\end{array}$ & 36 & $\begin{array}{l}14 \\
17\end{array}$ \\
\hline natuur en gezondheid & 13 & 58 & 29 & 6 & 25 & 14 \\
\hline natuur en techniek & 15 & 38 & 29 & 11 & 20 & 27 \\
\hline Totaal & 17 & 48 & 11 & 13 & 28 & 16 \\
\hline \multicolumn{7}{|l|}{ VWO nieuwe stijl - HBO } \\
\hline economie en maatschappij & 16 & 64 & 12 & 12 & 29 & 18 \\
\hline natuur en gezondheid & 8 & 60 & 26 & 8 & 25 & 14 \\
\hline natuur en techniek & 15 & 78 & 15 & 12 & 46 & 15 \\
\hline Totaal & 13 & 56 & 14 & 13 & 26 & 22 \\
\hline \multicolumn{7}{|l|}{ VWO nieuwe stijl - WO } \\
\hline economie en maatschappij & 27 & 37 & 5 & 19 & 38 & 23 \\
\hline natuur en gezondheid & 8 & 44 & 6 & 2 & 28 & 30 \\
\hline natuur en techniek & 25 & 33 & 11 & 5 & 16 & 41 \\
\hline Totaal & 20 & 36 & 5 & 17 & 27 & 30 \\
\hline
\end{tabular}

Van de VWO'ers die doorstromen naar het HBO zeggen schoolverlaters met het studieprofiel cultuur en maatschappij duidelijk minder vaak dan VWO'ers met een ander profiel dat het gevolgde profiel onvoldoende aansluit bij de vervolgopleiding. Daarnaast valt bij VWO'ers die doorstromen naar het HBO op dat relatief veel schoolverlaters met het profiel natuur en techniek zeggen niet opnieuw te kiezen voor het gevolgde profiel omdat deze niet aansluit bij de talenten. Bij VWO'ers die verder studeren in het WO geven relatief veel schoolverlaters met het profiel cultuur en maatschappij aan dat ze met het gevolgde profiel maar weinig kanten op kunnen. Verder zeggen hier vooral schoolverlaters met het studieprofiel economie en maatschappij dat het gevolgde profiel niet goed aansluit bij de talenten. 


\section{Hulp bij studie- of beroepskeuze}

In het laatste hoofdstuk van dit rapport wordt ingegaan op de hulp die HAVO- en VWO-schoolverlaters hebben gehad bij de studie- of beroepskeuze. Eerst wordt de informatie die schoolverlaters hebben ontvangen over de studie- en beroepskeuze besproken. Vervolgens wordt ingegaan op de kwaliteit van de aangeboden informatie volgens de schoolverlaters. Verder wordt ingegaan op de vraag welke informatiebronnen schoolverlaters hebben gebruikt en welke daarbij het nuttigst is geweest. Tot slot wordt ingegaan op het algemeen oordeel van schoolverlaters over de hulp die ze hebben gekregen bij de studie- of beroepskeuze.

Tabel 8.1

Aandeel HAVO/VWO-schoolverlaters oude en nieuwe stijl dat informatie over de studie- en beroepskeuze heeft gekregen ( 9 items)

\begin{tabular}{lccccccccc}
\hline & 1 & 2 & 3 & 4 & 5 & 6 & 7 & 8 & 9 \\
\hline HAVO oude stijl - HBO & 94 & 92 & 98 & 94 & 83 & 86 & 89 & 91 & 89 \\
VWO oude stijl - HBO & 97 & 95 & 98 & 92 & 78 & 84 & 87 & 89 & 87 \\
VWO oude stijl - WO & 96 & 93 & 98 & 93 & 80 & 88 & 86 & 90 & 87 \\
& & & & & & & & & \\
HAVO nieuwe stijl - HBO & 98 & 98 & 98 & 96 & 77 & 81 & 81 & 90 & 81 \\
VWO nieuwe stijl - HBO & 99 & 99 & 99 & 98 & 76 & 79 & 81 & 90 & 81 \\
VWO nieuwe stijl - WO & 99 & 99 & 99 & 96 & 79 & 85 & 84 & 90 & 84
\end{tabular}

Antwoordcategorieën: 1) goed 2) redelijk 3) matig 4) slecht 5) geen informatie gehad. In de tabel is het aandeel schoolverlaters vermeld dat informatie heeft gekregen (antwoordcategorie 1, 2, 3 of 4)

1) informatie over de mogelijkheden van verschillende vakkenpakketten

2) informatie bij de keuze van een vakkenpakket

3) informatie over vervolgopleidingen

4) informatie over de hulp bij het kiezen van vervolgopleidingen

$5)$ informatie over de inhoud van de lessen op de vervolgopleiding

6 informatie over de manier waarop les wordt gegeven op de vervolgopleiding

7) informatie over de moeilijkheidsgraad van de vervolgopleiding

8) informatie over de beroepen die je met een vervolgopleiding kunt uitoefenen

9) informatie over de kans op werk met vervolgopleiding

Schoolverlaters kunnen over verschillende items die gerelateerd zijn aan de studieen beroepskeuze worden geïnformeerd. In tabel 8.1 staan negen van deze items vermeld. Aan de schoolverlaters is gevraagd of ze informatie over deze items hebben gehad. Duidelijk wordt uit tabel 8.1 dat bijna alle schoolverlaters van het HAVO en het VWO informatie hebben gehad over de mogelijkheden van verschillende vakkenpakketten, informatie bij de keuze van een vakkenpakket, informatie over vervolgopleidingen en informatie over de hulp bij het kiezen van vervolgopleiding. Bij de overige items zien we dat het aandeel schoolverlaters dat informatie heeft ontvangen lager is, maar hier geldt nog steeds dat het overgrote deel van de schoolverlaters informatie heeft gekregen. Daarbij bestaan kleine verschillen tussen schoolverlaters oude en nieuwe stijl. Schoolverlaters zeggen na de invoering van de tweede fase over het algemeen iets minder vaak dan voorheen informatie te hebben ontvangen over de inhoud van de lessen op de vervolg- 
opleiding, de manier van lesgeven op de vervolgopleiding, de moeilijkheidsgraad van de vervolgopleiding en de kans op werk met de vervolgopleiding.

\section{Figuur 8.1}

Gemiddelde kwaliteitscores HAVO/VWO-schoolverlaters oude en nieuwe stijl informatie over de studie- en beroepskeuze ${ }^{1}$

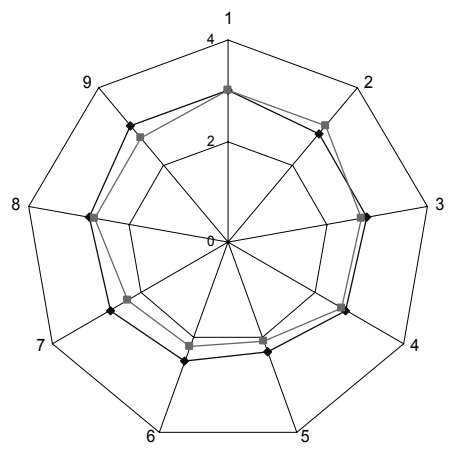

$\rightarrow-$ HAVO oude stij - HBO $\rightarrow-$ HAVO nieuwe stijl - HBO

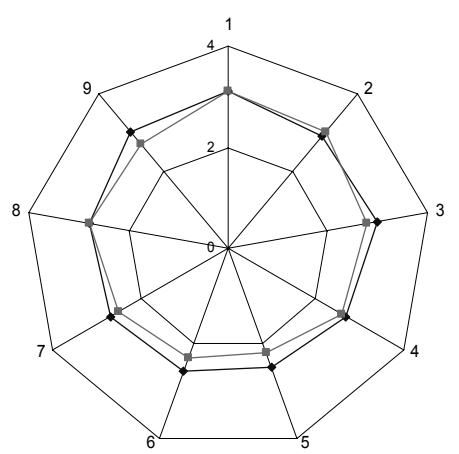

$\rightarrow-$ WWO oude stij - HBO $\rightarrow-$ WWO nieuwe stijl - HBO

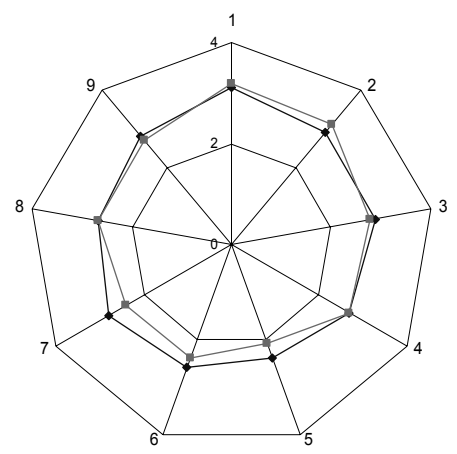

$\rightarrow-W O$ oude stij - WO $\rightarrow-W$ WO nieuwe stij - WO

${ }^{1}$ De kwaliteitscores zijn bepaald aan de hand van de vraag over de kwaliteit van negen verschillende informatiebronnen (antwoordcategorieën goed, redelijk, matig slecht). Voor de bepaling van de gemiddelde score zijn de volgende waarden aan de betreffende antwoordcategorieën toegekend; goed=4, redelijk=3, matig $=2$, slecht $=1$

1) informatie over de mogelijkheden van verschillende vakkenpakketten

2) informatie bij de keuze van een vakkenpakket

3) informatie over vervolgopleidingen

4) informatie over de hulp bij het kiezen van vervolgopleidingen

5) informatie over de inhoud van de lessen op de vervolgopleiding

6) informatie over de manier waarop les wordt gegeven op de vervolgopleiding

7) informatie over de moeilijkheidsgraad van de vervolgopleiding

8 ) informatie over de beroepen die je met een vervolgopleiding kunt uitoefenen

9 ) informatie over de kans op werk met vervolgopleiding

In tabel 6 van de bijlage is het aandeel schoolverlaters dat informatie heeft ontvangen over de negen items met betrekking tot studie- en beroepskeuze vermeld voor de verschillende profielen. Tabellen $7 a, 7 b$ en $7 c$ van de bijlage laten de 
resultaten zien van de multivariate analyse van de kans dat schoolverlaters informatie hebben gekregen over de betreffende items.

De schoolverlaters hebben kunnen aangeven wat ze vinden van de kwaliteit van de ontvangen informatie: 1) goed, 2) redelijk, 3) matig en 4) slecht. Figuur 8.1 laat de gemiddelde score hiervan zien voor schoolverlaters oude en nieuwe stijl. In tabel 8 van de bijlage zijn deze kwaliteitscores voor de verschillende profielen vermeld, en in de tabellen 9 a tot met $9 \mathrm{c}$ van de bijlage zijn de resultaten van de multivariate analyse van de kwaliteitscores weergegeven.

Allereerst blijkt uit figuur 8.1 dat voor HAVO- en VWO-schoolverlaters de kwaliteitscores gemiddeld het hoogst zijn bij informatie over de mogelijkheden van verschillende vakkenpakketten en informatie over de keuze van een vakkenpakket. De scores liggen hier voor schoolverlaters oude en nieuwe stijl om en nabij de 3,0. Dit betekent dat de gemiddelde schoolverlater aangeeft redelijk tevreden te zijn over deze informatie. Bij informatie over de inhoud van de lessen op de vervolgopleiding, de manier waarop les wordt gegeven op de vervolgopleiding en de moeilijkheidsgraad van de vervolgopleiding zijn de gemiddelde kwaliteitscores van schoolverlaters wat lager. Deze liggen om en nabij de 2,5. Daarbij geldt dat schoolverlaters nieuwe stijl hier over het algemeen genomen lager scoren dan schoolverlaters oude stijl. Dit betekent dat schoolverlaters niet alleen minder vaak informatie hebben gekregen over de inhoud van de lessen op de vervolgopleiding, de manier waarop les wordt gegeven op de vervolgopleiding en de moeilijkheidsgraad van de vervolgopleiding dan schoolverlaters oude stijl, maar ook vaker aangeven minder tevreden te zijn over de kwaliteit van de geboden informatie. Hetzelfde zien we overigens bij informatie over de kans op werk met de vervolgopleiding waar schoolverlaters nu doorgaans minder vaak tevreden zijn over de informatie dan voorheen.

Daarnaast is aan de schoolverlaters gevraagd aan te geven welke informatiebronnen zijn gebruikt bij de studiekeuze en welke daarbij het nuttigst werden ervaren. Tabellen 8.3 en 8.4 laten de resultaten hiervan zien. In de tabellen 10 en 11 van de bijlage zijn de resultaten voor de verschillende profielen weergegeven. In de tabellen $12 \mathrm{a}$ tot en met $13 \mathrm{c}$ zijn de resultaten van de multivariate analyses weergegeven.

Uit tabel 8.3 komt naar voren dat HAVO/VWO-schoolverlaters het vaakst zeggen opendagen bij de vervolgopleiding te gebruiken als informatiebron voor de studiekeuze. Ongeveer $90 \%$ van de schoolverlaters geeft aan naar opendagen te zijn geweest. Deze worden door schoolverlaters ook het vaakst nuttig gevonden (zie tabel 8.4). Daarnaast wordt door schoolverlaters relatief veel gebruik gemaakt van folders en computers/internet. In het huidige internettijdperk gebruiken schoolverlaters bij de studiekeuze vaker computers/internet en minder vaak folders dan vroeger. Overigens worden computers/internet en folders niet bijzonder vaak nuttig gevonden bij de studiekeuze. Verder blijkt dat schoolverlaters na de invoering van de tweede fase wat vaker gebruik maken van meeloopdagen bij de vervolgopleiding en wat minder gebruik maken van de begeleiding op school door leraren, mentoren of 
decanen. Opvallend zijn hier de meeloopdagen, die door schoolverlaters relatief vaak worden genoemd als de meest nuttige informatiebron bij de studiekeuze.

Tabel 8.3

Aandeel HAVO/VWO-schoolverlaters oude en nieuwe stijl dat gebruik heeft gemaakt van de betreffende informatiebron

\begin{tabular}{|c|c|c|c|c|c|c|}
\hline & $\begin{array}{l}\text { Begelei- } \\
\text { ding op } \\
\text { school }\end{array}$ & $\begin{array}{c}\text { Open- } \\
\text { dagen } \\
\text { vervolg- } \\
\text { opleiding }\end{array}$ & $\begin{array}{l}\text { Meeloop- } \\
\text { dagen } \\
\text { vervolg- } \\
\text { opleiding }\end{array}$ & Folders & $\begin{array}{l}\text { Compu- } \\
\text { ters/ } \\
\text { internet }\end{array}$ & Anders \\
\hline \multicolumn{7}{|l|}{ Totaal } \\
\hline HAVO oude stijl - HBO & 53 & 88 & 27 & 75 & 25 & 23 \\
\hline VWO oude stijl - HBO & 60 & 89 & 23 & 79 & 33 & 24 \\
\hline VWO oude stijl - WO & 57 & 90 & 34 & 85 & 39 & 17 \\
\hline HAVO nieuwe stijl - HBO & 49 & 87 & 30 & 67 & 61 & 18 \\
\hline VWO nieuwe stijl - HBO & 49 & 90 & 31 & 76 & 66 & 21 \\
\hline VWO nieuwe stijl - WO & 53 & 91 & 40 & 80 & 72 & 15 \\
\hline
\end{tabular}

${ }^{*}$ meerdere antwoorden mogelijk

Tabel 8.4

Informatiebron die HAVO/VWO-schoolverlaters het nuttigst vinden bij de studie- beroepskeuze, naar profiel* $^{*}$

\begin{tabular}{lcccccc}
\hline & $\begin{array}{c}\text { Begelei- } \\
\text { ding op } \\
\text { school }\end{array}$ & $\begin{array}{c}\text { Open- } \\
\text { dagen } \\
\text { vervolg- } \\
\text { opleiding }\end{array}$ & $\begin{array}{c}\text { Meeloop- } \\
\text { dagen } \\
\text { vervolg- } \\
\text { opleiding }\end{array}$ & $\begin{array}{c}\text { Folders } \\
\text { Compu- }\end{array}$ & $\begin{array}{c}\text { Anders } \\
\text { internet }\end{array}$ \\
\hline Totaal & & & & & & 7 \\
HAVO nieuwe stijl - HBO & 6 & 50 & 18 & 8 & 7 \\
VWO nieuwe stijl - HBO & 5 & 48 & 18 & 10 & 10 & 10 \\
VWO nieuwe stijl - WO & 4 & 46 & 24 & 11 & 9 & 6 \\
*Eén antwoord mogelijk & & & & & &
\end{tabular}

* Eén antwoord mogelijk

Aan schoolverlaters is ook gevraagd een algemeen oordeel te geven over de hulp die ze hebben gehad bij de keuze van een vervolgopleiding of een beroep. Dit is gemeten op een vijfpuntschaal die loopt van zeer ontevreden tot zeer tevreden. Tabel 8.5 vermeldt het aandeel schoolverlaters dat (zeer) tevreden is over deze hulp (antwoordcategorieën 4 en 5). Tabel 14 van de bijlage laat de resultaten zien van de kans dat schoolverlaters (zeer) tevreden zijn over de hulp bij de keuze van een vervolgopleiding of een beroep.

Uit tabel 8.5 komt naar voren dat schoolverlaters nu wat minder positief zijn in hun oordeel over de hulp bij studie- of beroepskeuze dan voorheen. Zowel bij havisten die doorgaan naar het $\mathrm{HBO}$ als bij VWO'ers die doorstromen naar het $\mathrm{HBO}$ en WO is het aandeel schoolverlaters nieuwe stijl dat (zeer) tevreden is over de hulp bij de keuze van een vervolgopleiding of een beroep lager dan bij schoolverlaters oude stijl. 
Daarbij geldt dat schoolverlaters met het studieprofiel economie en maatschappij minder vaak tevreden zijn over deze hulp dan schoolverlaters die een ander profiel hebben gevolgd.

Tabel 8.5

Aandeel HAVO/VWO-schoolverlaters oude en nieuwe stijl dat (zeer) tevreden is over de hulp die ze hebben gehad bij de keuze van een vervolgopleiding of een beroep

\begin{tabular}{lccccc}
\hline & totaal & $\begin{array}{c}\text { cultuur } \\
\text { en } \\
\text { matschappij }\end{array}$ & $\begin{array}{c}\text { economie } \\
\text { en } \\
\text { matschappij }\end{array}$ & $\begin{array}{c}\text { natuur } \\
\text { en } \\
\text { gezondheid }\end{array}$ & $\begin{array}{c}\text { natuur en } \\
\text { techniek }\end{array}$ \\
\hline HAVO oude stijl - HBO & 39 & n.v.t. & n.v.t. & n.v.t. & n.v.t. \\
VWO oude stijl - HBO & 37 & n.v.t. & n.v.t. & n.v.t. & n.v.t. \\
VWO oude stijl - WO & 43 & n.v.t. & n.v.t. & n.v.t. & n.v.t. \\
HAVO nieuwe stijl - HBO & 33 & 39 & 28 & 36 & 32 \\
VWO nieuwe stijl - HBO & 34 & 38 & 29 & 36 & 39 \\
VWO nieuwe stijl - WO & 37 & 40 & 32 & 41 & 39
\end{tabular}

Antwoord 4 of 5 op een schaal van 1 (zeer ontevreden) t/m 5 (zeer tevreden) n.v.t. = niet van toepassing

Geconcludeerd kan worden dat op allerlei terreinen HAVO- en VWO-schoolverlaters positiever zijn na de invoering van de tweede fase. Hier zien we dit echter niet. Mogelijk heeft dit te maken met een toegenomen zelfstandigheid van de scholieren na de invoering van de tweede fase. In een dergelijke situatie, waar de leerling geacht wordt meer informatie zelfstandig te verzamelen, wordt de hulp bij de studieof beroepskeuze wellicht als te gering ervaren. 



\section{Bijlage}

Tabel 1a

Multivariate analyse van de kans dat schoolverlaters de vaardigheid (heel) veel nodig hebben in de vervolgopleiding

\begin{tabular}{|c|c|c|c|c|c|c|c|c|c|c|c|c|}
\hline HAVO nieuwe stijl - HBO & 1 & 2 & 3 & 4 & 5 & 6 & 7 & 8 & 9 & 10 & 11 & 12 \\
\hline \multicolumn{13}{|l|}{ Geslacht } \\
\hline vrouw & ref. & ref. & ref. & ref. & ref. & ref. & ref. & ref. & ref. & ref. & ref. & ref. \\
\hline man & - & - & - & 0 & 0 & - & - & - & 0 & 0 & - & 0 \\
\hline \multicolumn{13}{|l|}{ Profiel } \\
\hline cultuur en maatschappij & 0 & 0 & 0 & 0 & 0 & 0 & 0 & 0 & - & 0 & 0 & 0 \\
\hline economie en maatschappij & ref. & ref. & ref. & ref. & ref. & ref. & ref. & ref. & ref. & ref. & ref. & ref. \\
\hline natuur en gezondheid & 0 & 0 & 0 & 0 & + & 0 & 0 & 0 & 0 & 0 & 0 & 0 \\
\hline natuur en techniek & 0 & 0 & 0 & - & 0 & 0 & 0 & - & + & 0 & 0 & 0 \\
\hline Profieloverstap & 0 & 0 & 0 & 0 & 0 & 0 & 0 & 0 & 0 & 0 & 0 & 0 \\
\hline Gemiddeld examencijfer & 0 & 0 & 0 & + & 0 & 0 & 0 & 0 & 0 & 0 & 0 & 0 \\
\hline \multicolumn{13}{|l|}{ Hoogst behaalde vooropleiding } \\
\hline geen & ref. & ref. & ref. & ref. & ref. & ref. & ref. & ref. & ref. & ref. & ref. & ref. \\
\hline mavo & 0 & 0 & 0 & 0 & 0 & 0 & 0 & 0 & 0 & 0 & 0 & 0 \\
\hline anders & 0 & 0 & 0 & 0 & 0 & 0 & 0 & 0 & 0 & 0 & 0 & 0 \\
\hline Duur havo opleiding & 0 & 0 & 0 & 0 & - & 0 & 0 & 0 & 0 & 0 & 0 & 0 \\
\hline \multicolumn{13}{|l|}{ Sector vervolgopleiding } \\
\hline landbouw & 0 & 0 & 0 & 0 & 0 & 0 & 0 & 0 & 0 & 0 & 0 & 0 \\
\hline onderwijs & 0 & + & 0 & 0 & 0 & 0 & - & 0 & + & - & 0 & - \\
\hline techniek & 0 & 0 & 0 & 0 & - & 0 & 0 & - & + & + & + & 0 \\
\hline economie & ref. & ref. & ref. & ref. & ref. & ref. & ref. & ref. & ref. & ref. & ref. & ref. \\
\hline gezondheidszorg & 0 & - & 0 & 0 & 0 & 0 & 0 & - & - & - & 0 & 0 \\
\hline gedrag en maatschappij & 0 & 0 & 0 & + & 0 & 0 & 0 & 0 & - & - & 0 & + \\
\hline taal en cultuur & 0 & + & 0 & 0 & - & 0 & - & - & - & 0 & 0 & 0 \\
\hline
\end{tabular}

Antwoord 4 of 5 op een schaal van 1 (vrijwel niet) t/m 5 (heel veel)

ref.= referentie

- = negatief significant effect op 5\%-niveau

$0=$ geen significant effect op $5 \%$-niveau

$+=$ positief significant effect op $5 \%$-niveau

$\begin{array}{lll}\text { 1) zelfstandig werken } & \text { 5) samenwerken } & \text { 9) rekenvaardigheden } \\ \text { 2) creativiteit } & \text { 6) studieplanning } & \text { 10) computervaardigheden } \\ \text { 3) initiatief } & \text { 7) informatie verzamelen en verwerken } & \text { 11) nauwkeurig werken } \\ \text { 4) communicatieve vaardigheden } & \text { 8) taalvaardigheid } & \text { 12) analytische vaardighd. }\end{array}$


Tabel $1 b$

Multivariate analyse van de kans dat schoolverlaters de vaardigheid (heel) veel nodig hebben in de vervolgopleiding

\begin{tabular}{|c|c|c|c|c|c|c|c|c|c|c|c|c|}
\hline VWO nieuwe stijl - HBO & 1 & 2 & 3 & 4 & 5 & 6 & 7 & 8 & 9 & 10 & 11 & 12 \\
\hline \multicolumn{13}{|l|}{ Geslacht } \\
\hline vrouw & ref. & ref. & ref. & ref. & ref. & ref. & ref. & ref. & ref. & ref. & ref. & ref. \\
\hline man & 0 & 0 & - & 0 & - & - & 0 & 0 & 0 & 0 & - & 0 \\
\hline \multicolumn{13}{|l|}{ Profiel } \\
\hline cultuur en maatschappij & 0 & + & 0 & 0 & 0 & 0 & 0 & 0 & 0 & 0 & 0 & 0 \\
\hline economie en maatschappij & ref. & ref. & ref. & ref. & ref. & ref. & ref. & ref. & ref. & ref. & ref. & ref. \\
\hline natuur en gezondheid & 0 & 0 & 0 & 0 & 0 & 0 & 0 & 0 & 0 & 0 & 0 & 0 \\
\hline natuur en techniek & 0 & 0 & 0 & 0 & 0 & 0 & - & 0 & 0 & 0 & 0 & 0 \\
\hline Profieloverstap & 0 & 0 & 0 & 0 & 0 & 0 & 0 & 0 & - & 0 & 0 & 0 \\
\hline $\begin{array}{l}\text { Gemiddeld examencijfer } \\
\text { Hoogst behaalde yooropleidina }\end{array}$ & 0 & 0 & 0 & 0 & 0 & 0 & 0 & 0 & - & 0 & 0 & 0 \\
\hline geen & ref. & ref. & ref. & ref. & ref. & ref. & ref. & ref. & ref. & ref. & ref. & ref. \\
\hline havo & 0 & 0 & 0 & 0 & 0 & 0 & 0 & 0 & 0 & 0 & 0 & 0 \\
\hline anders & 0 & 0 & 0 & 0 & 0 & 0 & 0 & 0 & 0 & 0 & 0 & 0 \\
\hline Duur vwo opleiding & 0 & - & 0 & 0 & 0 & 0 & 0 & 0 & 0 & 0 & 0 & 0 \\
\hline \multicolumn{13}{|l|}{ Sector vervolgopleiding } \\
\hline landbouw & 0 & 0 & 0 & 0 & 0 & 0 & 0 & 0 & 0 & - & 0 & 0 \\
\hline onderwijs & 0 & + & 0 & 0 & 0 & 0 & - & 0 & + & - & - & - \\
\hline techniek & 0 & 0 & 0 & - & 0 & - & 0 & - & 0 & 0 & 0 & 0 \\
\hline economie & ref. & ref. & ref. & ref. & ref. & ref. & ref. & ref. & ref. & ref. & ref. & ref. \\
\hline gezondheidszorg & 0 & 0 & 0 & 0 & 0 & 0 & 0 & - & - & - & 0 & 0 \\
\hline gedrag en maatschappij & 0 & 0 & 0 & 0 & 0 & 0 & 0 & 0 & - & - & - & 0 \\
\hline taal en cultuur & 0 & + & 0 & - & - & 0 & - & - & - & - & 0 & - \\
\hline
\end{tabular}

Antwoord 4 of 5 op een schaal van 1 (vrijwel niet) t/m 5 (heel veel)

ref.= referentie

- = negatief significant effect op 5\%-niveau

$0=$ geen significant effect op $5 \%$-niveau

$+=$ positief significant effect op $5 \%$-niveau

$\begin{array}{lll}\text { 1) zelfstandig werken } & \text { 5) samenwerken } & \text { 9) rekenvaardigheden } \\ \text { 2) creativiteit } & \text { 6) studieplanning } & \text { 10) computervaardigheden } \\ \text { 3) initiatief } & \text { 7) informatie verzamelen en verwerken } & \text { 11) nauwkeurig werken } \\ \text { 4) communicatieve vaardigheden } & \text { 8) taalvaardigheid } & \text { 12) analytische vaardighd. }\end{array}$


Tabel 1c

multivariate analyse van de kans dat schoolverlaters de vaardigheid (heel) veel nodig hebben in de vervolgopleiding

\begin{tabular}{|c|c|c|c|c|c|c|c|c|c|c|c|c|}
\hline VWO nieuwe stijl - WO & 1 & 2 & 3 & 4 & 5 & 6 & 7 & 8 & 9 & 10 & 11 & 12 \\
\hline \multicolumn{13}{|l|}{ Geslacht } \\
\hline vrouw & ref. & ref. & ref. & ref. & ref. & ref. & ref. & ref. & ref. & ref. & ref. & ref. \\
\hline man & 0 & + & - & - & - & - & - & - & - & - & 0 & 0 \\
\hline \multicolumn{13}{|l|}{ Profiel } \\
\hline cultuur en maatschappij & 0 & 0 & 0 & 0 & 0 & 0 & 0 & 0 & 0 & 0 & 0 & 0 \\
\hline economie en maatschappij & ref. & ref. & ref. & ref. & ref. & ref. & ref. & ref. & ref. & ref. & ref. & ref. \\
\hline natuur en gezondheid & 0 & 0 & 0 & 0 & 0 & 0 & 0 & 0 & 0 & 0 & 0 & 0 \\
\hline natuur en techniek & 0 & 0 & 0 & 0 & 0 & 0 & 0 & 0 & 0 & 0 & 0 & 0 \\
\hline Profieloverstap & 0 & 0 & + & 0 & 0 & 0 & 0 & 0 & 0 & 0 & 0 & 0 \\
\hline Gemiddeld examencijfer & 0 & 0 & - & 0 & - & 0 & 0 & - & 0 & 0 & 0 & + \\
\hline \multicolumn{13}{|l|}{ Hoogst behaalde vooropleiding } \\
\hline geen & ref. & ref. & ref. & ref. & ref. & ref. & ref. & ref. & ref. & ref. & ref. & ref. \\
\hline havo & 0 & 0 & 0 & 0 & 0 & 0 & 0 & 0 & 0 & 0 & 0 & 0 \\
\hline anders & 0 & 0 & 0 & 0 & 0 & 0 & 0 & 0 & 0 & 0 & 0 & 0 \\
\hline Duur vwo opleiding & 0 & 0 & 0 & 0 & 0 & 0 & 0 & 0 & 0 & + & 0 & + \\
\hline \multicolumn{13}{|l|}{ Sector vervolgopleiding } \\
\hline landbouw & - & 0 & - & 0 & + & 0 & 0 & 0 & - & - & 0 & 0 \\
\hline techniek & 0 & + & 0 & 0 & + & 0 & 0 & 0 & 0 & + & 0 & 0 \\
\hline economie & ref. & ref. & ref. & ref. & ref. & ref. & ref. & ref. & ref. & ref. & ref. & ref. \\
\hline gezondheidszorg & 0 & 0 & 0 & 0 & 0 & 0 & 0 & - & - & - & 0 & 0 \\
\hline gedrag en maatschappij & 0 & 0 & 0 & 0 & 0 & 0 & + & + & - & - & 0 & 0 \\
\hline taal en cultuur & 0 & 0 & 0 & 0 & - & 0 & + & + & - & - & 0 & 0 \\
\hline recht en openbare orde & 0 & 0 & - & 0 & - & 0 & 0 & - & - & - & + & 0 \\
\hline natuurwetenschappen & - & 0 & 0 & - & 0 & 0 & 0 & 0 & 0 & 0 & + & + \\
\hline
\end{tabular}

Antwoord 4 of 5 op een schaal van 1 (vrijwel niet) t/m 5 (heel veel)

ref.= referentie

- = negatief significant effect op 5\%-niveau

$0=$ geen significant effect op $5 \%$-niveau

$+=$ positief significant effect op $5 \%$-niveau
1) zelfstandig werken
5) samenwerken
2) creativiteit
6) studieplanning
9) rekenvaardigheden
3) initiatief
7) informatie verzamelen en verwerken
10) computervaardigheden
4) communicatieve vaardigheden 8) taalvaardigheid
11) nauwkeurig werken
12) analytische vaardighd. 
Tabel $2 a$

Multivariate analyse van de kans dat schoolverlaters de vaardigheid redelijk tot goed beheersen

\begin{tabular}{|c|c|c|c|c|c|c|c|c|c|c|c|c|}
\hline HAVO nieuwe stijl - HBO & 1 & 2 & 3 & 4 & 5 & 6 & 7 & 8 & 9 & 10 & 11 & 12 \\
\hline \multicolumn{13}{|l|}{ Geslacht } \\
\hline vrouw & ref. & ref. & ref. & ref. & ref. & ref. & ref. & ref. & ref. & ref. & ref. & ref. \\
\hline man & - & - & - & - & 0 & - & - & 0 & - & 0 & - & 0 \\
\hline \multicolumn{13}{|l|}{ Profiel } \\
\hline cultuur en maatschappij & 0 & + & 0 & 0 & 0 & 0 & 0 & + & 0 & 0 & 0 & 0 \\
\hline economie en maatschappij & ref. & ref. & ref. & ref. & ref. & ref. & ref. & ref. & ref. & ref. & ref. & ref. \\
\hline natuur en gezondheid & 0 & 0 & 0 & 0 & 0 & 0 & 0 & 0 & + & 0 & 0 & 0 \\
\hline natuur en techniek & 0 & 0 & 0 & 0 & 0 & 0 & 0 & 0 & + & + & 0 & 0 \\
\hline Profieloverstap & 0 & 0 & 0 & 0 & 0 & 0 & 0 & - & + & 0 & 0 & 0 \\
\hline Gemiddeld examencijfer & + & 0 & 0 & 0 & - & 0 & 0 & 0 & 0 & 0 & 0 & + \\
\hline \multicolumn{13}{|l|}{ Hoogst behaalde vooropleiding } \\
\hline geen & ref. & ref. & ref. & ref. & ref. & ref. & ref. & ref. & ref. & ref. & ref. & ref. \\
\hline mavo & - & 0 & 0 & 0 & - & 0 & 0 & + & 0 & - & 0 & 0 \\
\hline anders & 0 & 0 & 0 & 0 & 0 & 0 & 0 & 0 & 0 & 0 & 0 & 0 \\
\hline Duur havo opleiding & - & 0 & 0 & 0 & 0 & - & 0 & + & 0 & - & 0 & - \\
\hline \multicolumn{13}{|l|}{ Sector vervolgopleiding } \\
\hline landbouw & 0 & 0 & 0 & - & 0 & 0 & 0 & 0 & 0 & 0 & 0 & 0 \\
\hline onderwijs & - & 0 & 0 & 0 & 0 & 0 & 0 & 0 & + & 0 & 0 & 0 \\
\hline techniek & 0 & 0 & 0 & 0 & 0 & 0 & 0 & 0 & 0 & 0 & 0 & 0 \\
\hline economie & ref. & ref. & ref. & ref. & ref. & ref. & ref. & ref. & ref. & ref. & ref. & ref. \\
\hline gezondheidszorg & 0 & 0 & 0 & 0 & 0 & 0 & 0 & 0 & 0 & 0 & 0 & - \\
\hline gedrag en maatschappij & 0 & 0 & 0 & 0 & 0 & - & 0 & 0 & - & 0 & 0 & 0 \\
\hline taal en cultuur & 0 & 0 & 0 & 0 & 0 & 0 & 0 & 0 & 0 & 0 & 0 & 0 \\
\hline
\end{tabular}

antwoordcategorieën: 1) goed 2) redelijk 3) matig 4) slecht

ref. $=$ referentie

- = negatief significant effect op 5\%-niveau

$0=$ geen significant effect op 5\%-niveau

$+=$ positief significant effect op $5 \%$-niveau
1) zelfstandig werken
5) samenwerken
2) creativiteit
6) studieplanning
9) rekenvaardigheden
3) initiatief
7) informatie verzamelen en verwerken
10) computervaardigheden
12) analytiond

4) communicatieve vaardigheden 8) taalvaardigheid 
Tabel $2 b$

Multivariate analyse van de kans dat schoolverlaters de vaardigheid redelijk tot goed beheersen

\begin{tabular}{|c|c|c|c|c|c|c|c|c|c|c|c|c|}
\hline VWO nieuwe stijl - HBO & 1 & 2 & 3 & 4 & 5 & 6 & 7 & 8 & 9 & 10 & 11 & 12 \\
\hline \multicolumn{13}{|l|}{ Geslacht } \\
\hline vrouw & ref. & ref. & ref. & ref. & ref. & ref. & ref. & ref. & ref. & ref. & ref. & ref. \\
\hline man & 0 & 0 & 0 & - & - & - & 0 & 0 & - & 0 & - & 0 \\
\hline \multicolumn{13}{|l|}{ Profiel } \\
\hline cultuur en maatschappij & 0 & + & 0 & 0 & 0 & 0 & 0 & 0 & - & 0 & 0 & 0 \\
\hline economie en maatschappij & ref. & ref. & ref. & ref. & ref. & ref. & ref. & ref. & ref. & ref. & ref. & ref. \\
\hline natuur en gezondheid & 0 & 0 & 0 & 0 & 0 & 0 & 0 & 0 & 0 & 0 & 0 & 0 \\
\hline natuur en techniek & 0 & 0 & 0 & 0 & 0 & 0 & 0 & 0 & + & 0 & 0 & 0 \\
\hline Profieloverstap & 0 & 0 & 0 & 0 & 0 & 0 & 0 & 0 & 0 & 0 & 0 & 0 \\
\hline Gemiddeld examencijfer & + & 0 & 0 & - & 0 & 0 & 0 & 0 & + & 0 & 0 & 0 \\
\hline \multicolumn{13}{|l|}{ Hoogst behaalde vooropleiding } \\
\hline geen & ref. & ref. & ref. & ref. & ref. & ref. & ref. & ref. & ref. & ref. & ref. & ref. \\
\hline havo & 0 & 0 & 0 & 0 & 0 & 0 & 0 & 0 & 0 & 0 & 0 & 0 \\
\hline anders & 0 & 0 & 0 & 0 & 0 & 0 & 0 & 0 & 0 & 0 & 0 & 0 \\
\hline Duur vwo opleiding & 0 & 0 & 0 & 0 & 0 & 0 & 0 & 0 & 0 & 0 & 0 & 0 \\
\hline \multicolumn{13}{|l|}{ Sector vervolgopleiding } \\
\hline landbouw & 0 & 0 & 0 & 0 & 0 & 0 & 0 & 0 & 0 & 0 & 0 & 0 \\
\hline onderwijs & 0 & 0 & 0 & 0 & - & 0 & 0 & 0 & 0 & 0 & 0 & 0 \\
\hline techniek & 0 & 0 & 0 & 0 & 0 & 0 & - & - & 0 & 0 & 0 & 0 \\
\hline economie & ref. & ref. & ref. & ref. & ref. & ref. & ref. & ref. & ref. & ref. & ref. & ref. \\
\hline gezondheidszorg & 0 & 0 & 0 & 0 & 0 & 0 & 0 & 0 & 0 & 0 & 0 & 0 \\
\hline gedrag en maatschappij & 0 & 0 & 0 & 0 & 0 & 0 & 0 & 0 & 0 & 0 & 0 & 0 \\
\hline taal en cultuur & 0 & 0 & 0 & 0 & - & 0 & 0 & 0 & 0 & - & 0 & 0 \\
\hline
\end{tabular}

antwoordcategorieën: 1) goed 2) redelijk 3) matig 4) slecht

ref. $=$ referentie

- = negatief significant effect op 5\%-niveau

$0=$ geen significant effect op 5\%-niveau

$+=$ positief significant effect op $5 \%$-niveau
1) zelfstandig werken
5) samenwerken
2) creativiteit
6) studieplanning
3) initiatief
7) informatie verzamelen en verwerken
9) rekenvaardigheden
10) computervaardigheden
4) communicatieve vaardigheden 8) taalvaardigheid
12) analytische vaardighd. 
Tabel 2c

Multivariate analyse van de kans dat schoolverlaters de vaardigheid redelijk tot goed beheersen

\begin{tabular}{|c|c|c|c|c|c|c|c|c|c|c|c|c|}
\hline VWO nieuwe stijl - WO & 1 & 2 & 3 & 4 & 5 & 6 & 7 & 8 & 9 & 10 & 11 & 12 \\
\hline \multicolumn{13}{|l|}{ Geslacht } \\
\hline vrouw & ref. & ref. & ref. & ref. & ref. & ref. & ref. & ref. & ref. & ref. & ref. & ref. \\
\hline man & - & 0 & - & 0 & 0 & - & 0 & 0 & 0 & + & - & 0 \\
\hline \multicolumn{13}{|l|}{ Profiel } \\
\hline cultuur en maatschappij & 0 & + & 0 & 0 & 0 & - & 0 & 0 & - & 0 & 0 & 0 \\
\hline economie en maatschappij & ref. & ref. & ref. & ref. & ref. & ref. & ref. & ref. & ref. & ref. & ref. & ref. \\
\hline natuur en gezondheid & 0 & 0 & 0 & 0 & 0 & 0 & 0 & 0 & + & 0 & 0 & + \\
\hline natuur en techniek & 0 & 0 & 0 & 0 & 0 & 0 & + & 0 & + & + & 0 & 0 \\
\hline Profieloverstap & 0 & 0 & 0 & 0 & 0 & 0 & 0 & 0 & 0 & 0 & 0 & 0 \\
\hline Gemiddeld examencijfer & + & 0 & 0 & 0 & 0 & + & 0 & + & + & 0 & + & + \\
\hline \multicolumn{13}{|l|}{ Hoogst behaalde vooropleiding } \\
\hline geen & ref. & ref. & ref. & ref. & ref. & ref. & ref. & ref. & ref. & ref. & ref. & ref. \\
\hline havo & 0 & 0 & 0 & 0 & 0 & 0 & 0 & 0 & 0 & 0 & 0 & 0 \\
\hline anders & 0 & 0 & 0 & 0 & 0 & 0 & 0 & 0 & 0 & 0 & 0 & 0 \\
\hline Duur vwo opleiding & 0 & 0 & 0 & 0 & 0 & 0 & 0 & 0 & 0 & 0 & 0 & 0 \\
\hline \multicolumn{13}{|l|}{ Sector vervolgopleiding } \\
\hline landbouw & 0 & 0 & 0 & 0 & 0 & 0 & 0 & 0 & - & 0 & 0 & 0 \\
\hline techniek & 0 & 0 & 0 & - & 0 & 0 & - & 0 & - & - & 0 & 0 \\
\hline economie & ref. & ref. & ref. & ref. & ref. & ref. & ref. & ref. & ref. & ref. & ref. & ref. \\
\hline gezondheidszorg & + & 0 & 0 & 0 & 0 & 0 & 0 & 0 & - & 0 & 0 & 0 \\
\hline gedrag en maatschappij & + & 0 & 0 & 0 & 0 & 0 & 0 & 0 & - & 0 & 0 & 0 \\
\hline taal en cultuur & + & + & 0 & 0 & 0 & 0 & 0 & 0 & - & 0 & 0 & 0 \\
\hline recht en openbare orde & 0 & 0 & 0 & 0 & 0 & 0 & 0 & 0 & - & 0 & 0 & 0 \\
\hline natuurwetenschappen & + & 0 & 0 & - & 0 & 0 & 0 & 0 & - & 0 & 0 & 0 \\
\hline
\end{tabular}

antwoordcategorieën: 1) goed 2) redelijk 3) matig 4) slecht

ref.= referentie

- = negatief significant effect op 5\%-niveau

$0=$ geen significant effect op 5\%-niveau

$+=$ positief significant effect op $5 \%$-niveau

$\begin{array}{llc}\text { 1) zelfstandig werken } & \text { 5) samenwerken } & \text { 9) rekenvaardigheden } \\ \text { 2) creativiteit } & \text { 6) studieplanning } & \text { 10) computervaardigheden } \\ \text { 3) initiatief } & \text { 7) informatie verzamelen en verwerken } & \text { 11) nauwkeurig werken } \\ \text { 4) communicatieve vaardigheden } & \text { 8) taalvaardigheid } & \text { 12) analytische vaardighd. }\end{array}$


Tabel 3

Aandeel HAVO/VWO-schoolverlaters oude en nieuwe stijl dat de betreffende vaardigheid vooral in het HAVO/VWO, HBO/WO of elders heeft geleerd, naar profiel

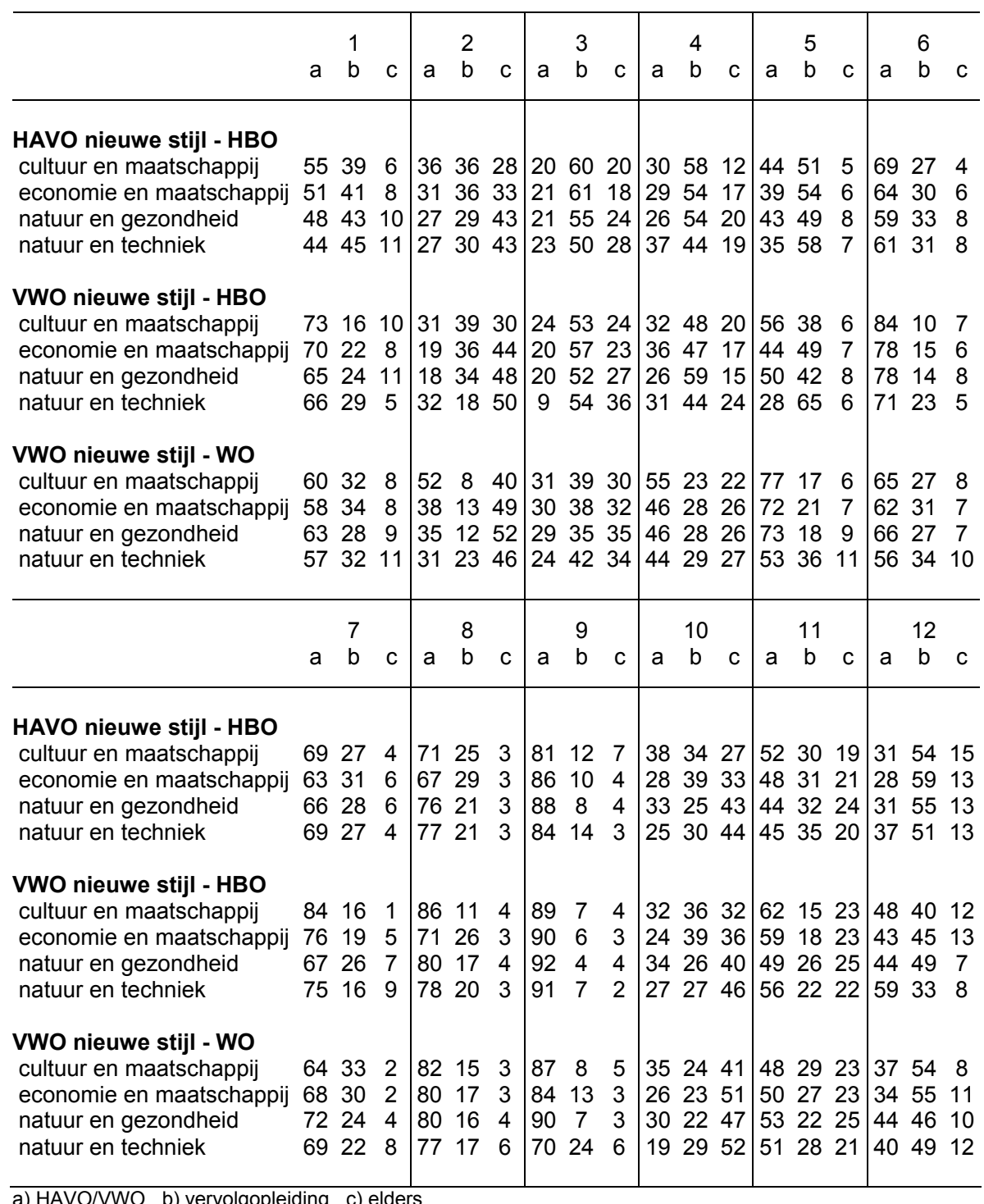

a) HAVO/VWO b) vervolgopleiding c) elders

$\begin{array}{lll}\text { 1) zelfstandig werken } & \text { 5) samenwerken } & \text { 9) rekenvaardigheden } \\ \text { 2) creativiteit } & \text { 6) studieplanning } & \text { 10) computervaardigheden } \\ \text { 3) initiatief } & \text { 7) informatie verzamelen en verwerken } & \text { 11) nauwkeurig werken } \\ \text { 4) communicatieve vaardigheden } & \text { 8) taalvaardigheid } & \text { 12) analytische vaardighd. }\end{array}$


Tabel $4 a$

Multivariate analyse van de kans dat schoolverlaters de vaardigheid vooral hebben geleerd in de vervolgopleiding of elders (t.o.v de HAVO-opleiding)

\begin{tabular}{|c|c|c|c|c|c|c|c|c|c|c|c|c|c|c|c|c|c|c|}
\hline \multirow[t]{2}{*}{ HAVO nieuwe stijl - HBO } & \multicolumn{3}{|c|}{1} & \multicolumn{3}{|c|}{2} & \multicolumn{3}{|c|}{3} & \multicolumn{3}{|c|}{4} & \multicolumn{3}{|c|}{5} & \multicolumn{3}{|c|}{6} \\
\hline & a & $\mathrm{b}$ & $\mathrm{C}$ & $a$ & $\mathrm{~b}$ & $\mathrm{C}$ & $a$ & b & C & a & $\mathrm{b}$ & C & $a$ & $\mathrm{~b}$ & c & a & $b$ & $\mathrm{C}$ \\
\hline \multicolumn{19}{|l|}{ Geslacht } \\
\hline vrouw & & r. & r. & & r. & r. & & r. & r. & & r. & r. & & r. & r. & & r. & r. \\
\hline man & & + & 0 & & 0 & 0 & & 0 & 0 & & 0 & + & & 0 & 0 & & + & 0 \\
\hline \multicolumn{19}{|l|}{ Profiel } \\
\hline cultuur en maatschappij & & 0 & 0 & & - & - & & 0 & + & & 0 & 0 & & 0 & 0 & & 0 & 0 \\
\hline economie en maatschappij & & r. & r. & & r. & r. & & $\mathrm{r}$. & r. & & r. & r. & & r. & r. & & r. & r. \\
\hline natuur en gezondheid & & 0 & 0 & & 0 & 0 & & 0 & 0 & & 0 & 0 & & 0 & 0 & & 0 & 0 \\
\hline natuur en techniek & & 0 & 0 & & - & 0 & & 0 & 0 & & 0 & 0 & & 0 & 0 & & 0 & 0 \\
\hline Profieloverstap & & 0 & 0 & & - & 0 & & 0 & 0 & & 0 & 0 & & 0 & 0 & & 0 & 0 \\
\hline Gemiddeld examencijfer & & 0 & 0 & & 0 & 0 & & 0 & 0 & & 0 & 0 & & + & 0 & & 0 & + \\
\hline $\begin{array}{ll}\text { Hoogst } & \text { behaalde } \\
\text { vooropleiding } & \end{array}$ & & & & & & & & & & & & & & & & & & \\
\hline geen & & r. & r. & & r. & r. & & r. & r. & & r. & r. & & r. & r. & & r. & r. \\
\hline mavo & & 0 & 0 & & 0 & 0 & & 0 & + & & 0 & + & & 0 & + & & 0 & 0 \\
\hline anders & & 0 & 0 & & 0 & 0 & & 0 & + & & 0 & 0 & & 0 & 0 & & 0 & + \\
\hline Duur havo opleiding & & 0 & 0 & & 0 & 0 & & 0 & 0 & & 0 & 0 & & 0 & + & & 0 & 0 \\
\hline \multicolumn{19}{|l|}{ Sector vervolgopleiding } \\
\hline landbouw & & 0 & 0 & & 0 & 0 & & 0 & 0 & & 0 & 0 & & 0 & 0 & & 0 & 0 \\
\hline onderwijs & & - & 0 & & + & + & & 0 & 0 & & - & 0 & & - & 0 & & 0 & 0 \\
\hline techniek & & - & 0 & & 0 & + & & 0 & 0 & & - & - & & 0 & 0 & & 0 & 0 \\
\hline economie & & r. & r. & & r. & r. & & r. & r. & & r. & r. & & r. & r. & & r. & r. \\
\hline gezondheidszorg & & 0 & 0 & & - & 0 & & 0 & 0 & & 0 & 0 & & - & 0 & & 0 & 0 \\
\hline gedrag en maatschappij & & 0 & 0 & & 0 & + & & 0 & 0 & & + & 0 & & 0 & 0 & & 0 & 0 \\
\hline taal en cultuur & & 0 & 0 & & + & + & & - & 0 & & - & 0 & & - & 0 & & 0 & 0 \\
\hline
\end{tabular}

a) HAVO (= referentie)

b) vervolgopleiding

c) elders

$\mathrm{r} .=$ referentie

- = negatief significant effect op 5\%-niveau

$0=$ geen significant effect op $5 \%$-niveau

$+=$ positief significant effect op $5 \%$-niveau

1) zelfstandig werken

2) creativiteit

3) initiatief

5) samenwerken

6) studieplanning

7) informatie verzamelen en verwerken

4) communicatieve vaardigheden 8) taalvaardigheid
9) rekenvaardigheden

10) computervaardigheden

11) nauwkeurig werken

12) analytische vaardighd 
Tabel 4a. (vervolg)

\begin{tabular}{|c|c|c|c|c|c|c|c|c|c|c|c|c|c|c|c|c|c|}
\hline \multirow[t]{2}{*}{ HAVO nieuwe stijl - HBO } & \multicolumn{2}{|l|}{7} & \multicolumn{3}{|c|}{8} & \multicolumn{3}{|c|}{9} & \multicolumn{3}{|c|}{10} & \multicolumn{3}{|c|}{11} & \multicolumn{3}{|c|}{12} \\
\hline & $a b$ & $\mathrm{C}$ & a & $b$ & $\mathrm{C}$ & a & $b$ & c & a & $\mathrm{b}$ & $\mathrm{C}$ & a & $b$ & C & a & $\mathrm{b}$ & c \\
\hline \multicolumn{18}{|l|}{ Geslacht } \\
\hline vrouw & r. & $r$. & & r. & r. & & r. & r. & & r. & r. & & r. & r. & & r. & r. \\
\hline man & 0 & + & & 0 & 0 & & 0 & 0 & & 0 & + & & 0 & - & & 0 & 0 \\
\hline \multicolumn{18}{|l|}{ Profiel } \\
\hline cultuur en maatschappij & 0 & 0 & & 0 & 0 & & + & 0 & & 0 & 0 & & 0 & 0 & & 0 & 0 \\
\hline economie en maatschappij & r. & $r$. & & r. & r. & & r. & r. & & r. & r. & & r. & r. & & r. & r. \\
\hline natuur en gezondheid & 0 & 0 & & 0 & 0 & & 0 & 0 & & 0 & 0 & & 0 & 0 & & 0 & 0 \\
\hline natuur en techniek & 0 & 0 & & 0 & 0 & & 0 & 0 & & 0 & 0 & & 0 & 0 & & 0 & 0 \\
\hline Profieloverstap & 0 & 0 & & 0 & 0 & & 0 & 0 & & 0 & 0 & & 0 & 0 & & 0 & 0 \\
\hline Gemiddeld examencijfer & 0 & 0 & & 0 & 0 & & - & 0 & & 0 & + & & 0 & 0 & & 0 & 0 \\
\hline Hoogst behaalde vooropleiding & & & & & & & & & & & & & & & & & \\
\hline geen & r. & $r$. & & r. & r. & & r. & r. & & r. & r. & & r. & r. & & r. & r. \\
\hline mavo & 0 & 0 & & 0 & 0 & & 0 & 0 & & 0 & 0 & & 0 & 0 & & 0 & 0 \\
\hline anders & 0 & 0 & & 0 & + & & 0 & 0 & & 0 & 0 & & 0 & 0 & & 0 & 0 \\
\hline Duur havo opleiding & 0 & + & & 0 & 0 & & 0 & 0 & & 0 & + & & 0 & 0 & & 0 & 0 \\
\hline \multicolumn{18}{|l|}{ Sector vervolgopleiding } \\
\hline landbouw & 0 & 0 & & 0 & 0 & & 0 & 0 & & 0 & - & & 0 & 0 & & 0 & 0 \\
\hline onderwijs & - & 0 & & - & 0 & & + & + & & - & 0 & & - & 0 & & - & 0 \\
\hline techniek & 0 & 0 & & 0 & 0 & & + & 0 & & 0 & 0 & & 0 & 0 & & 0 & 0 \\
\hline economie & r. & $r$. & & r. & $\mathrm{r}$. & & r. & r. & & r. & r. & & r. & r. & & r. & r. \\
\hline gezondheidszorg & 0 & 0 & & - & 0 & & - & 0 & & - & 0 & & 0 & 0 & & 0 & 0 \\
\hline gedrag en maatschappij & - & 0 & & 0 & 0 & & - & 0 & & - & 0 & & 0 & 0 & & 0 & 0 \\
\hline taal en cultuur & 0 & 0 & & 0 & 0 & & 0 & 0 & & 0 & 0 & & 0 & 0 & & - & 0 \\
\hline
\end{tabular}

a) HAVO (= referentie)

b) vervolgopleiding

c) elders

r.= referentie

- = negatief significant effect op 5\%-niveau

$0=$ geen significant effect op 5\%-niveau

$+=$ positief significant effect op $5 \%$-niveau

$\begin{array}{lll}\text { 1) zelfstandig werken } & \text { 5) samenwerken } & \text { 9) rekenvaardigheden } \\ \text { 2) creativiteit } & \text { 6) studieplanning } & \text { 10) computervaardigheden } \\ \text { 3) initiatief } & \text { 7) informatie verzamelen en verwerken } & \text { 11) nauwkeurig werken } \\ \text { 4) communicatieve vaardigheden } & \text { 8) taalvaardigheid } & \text { 12) analytische vaardighd. }\end{array}$


Tabel $4 b$

Multivariate analyse van de kans dat schoolverlaters de vaardigheid vooral hebben geleerd in de vervolgopleiding of elders (t.o.v de VWO-opleiding)

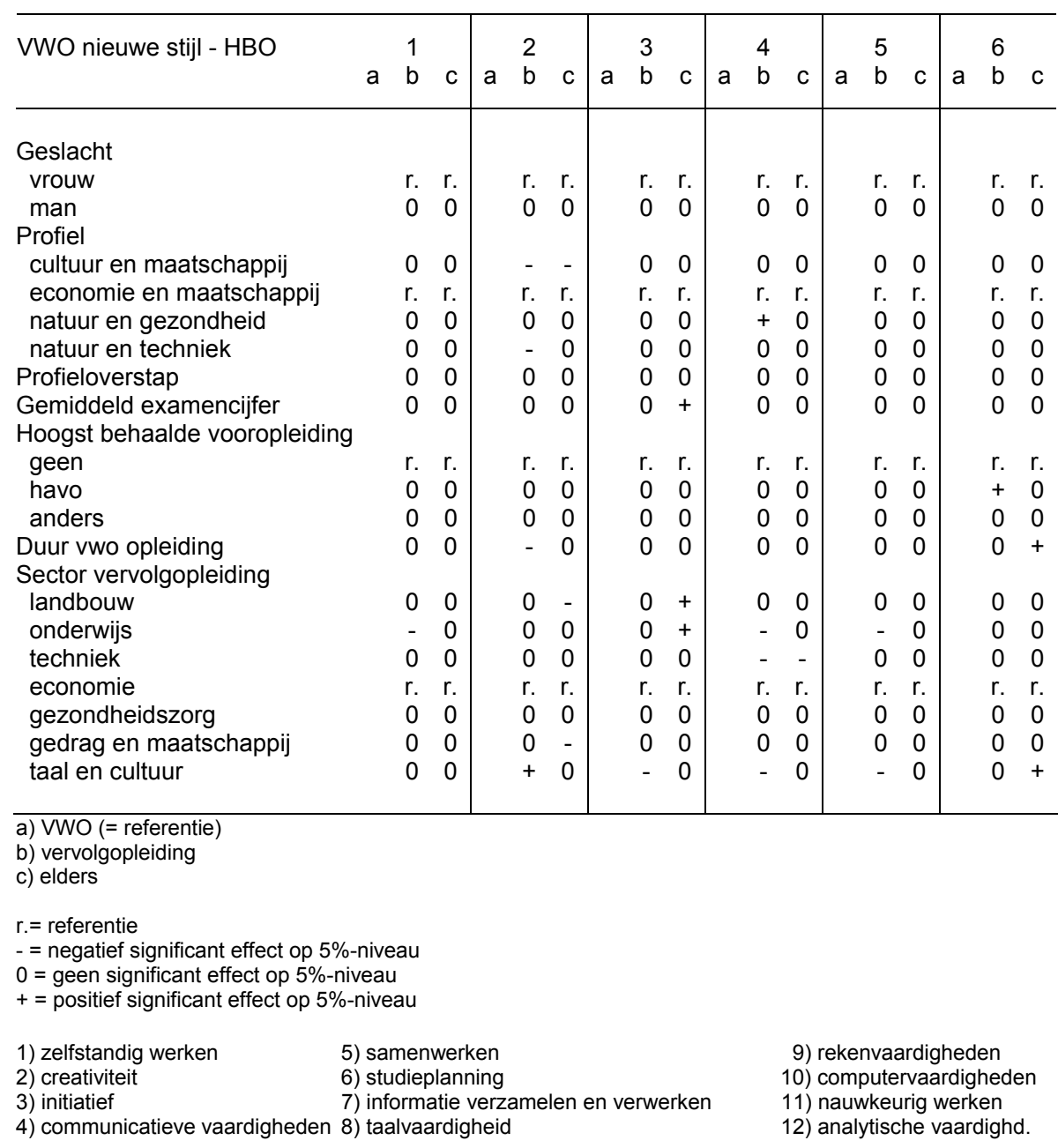


Tabel 4b. (vervolg)

\begin{tabular}{|c|c|c|c|c|c|c|c|c|c|c|c|c|c|c|c|c|}
\hline \multirow{2}{*}{ VWO nieuwe stijl - HBO } & \multicolumn{3}{|c|}{7} & \multicolumn{3}{|c|}{8} & \multicolumn{3}{|c|}{9} & \multicolumn{2}{|c|}{10} & \multicolumn{2}{|c|}{11} & \multicolumn{3}{|c|}{12} \\
\hline & a & $\mathrm{b}$ & c & a & b & c & $a$ & b & c & $a b$ & b c & $a \quad b$ & b c & a & b & c \\
\hline \multicolumn{17}{|l|}{ Geslacht } \\
\hline vrouw & & r. & r. & & r. & r. & & r. & r. & & r. $r$. & & r. $r$. & & r. & \\
\hline $\operatorname{man}$ & & 0 & 0 & & 0 & 0 & & 0 & 0 & & $0 \quad 0$ & & 00 & & 0 & 0 \\
\hline \multicolumn{17}{|l|}{ Profiel } \\
\hline cultuur en maatschappij & & 0 & 0 & & 0 & 0 & & 0 & 0 & & $0-$ & & $\begin{array}{ll}0 & 0\end{array}$ & & 0 & 0 \\
\hline economie en maatschappij & & r. & r. & & r. & r. & & r. & r. & & r. $r$. & & c. $r$. & & r. & r. \\
\hline natuur en gezondheid & & 0 & 0 & & 0 & 0 & & 0 & 0 & & $0 \quad 0$ & & 00 & & 0 & 0 \\
\hline natuur en techniek & & 0 & 0 & & 0 & 0 & & 0 & 0 & & $0 \quad 0$ & & 00 & & - & 0 \\
\hline Profieloverstap & & 0 & 0 & & 0 & 0 & & 0 & 0 & & 00 & & 00 & & 0 & 0 \\
\hline Gemiddeld examencijfer & & 0 & 0 & & 0 & 0 & & 0 & 0 & & $0 \quad 0$ & & 00 & & 0 & - \\
\hline \multicolumn{17}{|l|}{$\begin{array}{l}\text { Hoogst behaalde } \\
\text { vooropleiding }\end{array}$} \\
\hline geen & & r. & r. & & r. & r. & & r. & r. & & r. $r$. & & r. $r$. & & r. & r. \\
\hline havo & & 0 & 0 & & 0 & 0 & & 0 & 0 & & $0+$ & & 00 & & 0 & 0 \\
\hline anders & & 0 & 0 & & 0 & 0 & & 0 & 0 & & $0 \quad 0$ & & 00 & & 0 & 0 \\
\hline Duur vwo opleiding & & 0 & 0 & & + & 0 & & 0 & + & & $0 \quad 0$ & & $0+$ & & 0 & 0 \\
\hline \multicolumn{17}{|l|}{ Sector vervolgopleiding } \\
\hline landbouw & & + & 0 & & 0 & 0 & & 0 & 0 & & 00 & 0 & 00 & & 0 & 0 \\
\hline onderwijs & & 0 & 0 & & - & 0 & & + & + & & -0 & 0 & 00 & & 0 & 0 \\
\hline techniek & & - & 0 & & 0 & 0 & & 0 & 0 & & $0 \quad 0$ & 0 & 00 & & 0 & 0 \\
\hline economie & & r. & r. & & r. & r. & & r. & r. & & r. $r$. & & r. $r$. & & r. & r. \\
\hline gezondheidszorg & & 0 & 0 & & - & 0 & & 0 & 0 & & -0 & 0 & 00 & & 0 & 0 \\
\hline gedrag en maatschappij & & 0 & 0 & & - & 0 & & 0 & 0 & & -0 & 0 & 00 & & 0 & 0 \\
\hline taal en cultuur & & 0 & 0 & & - & 0 & & 0 & 0 & & -0 & 0 & 00 & & - & 0 \\
\hline
\end{tabular}

a) VWO (= referentie)

b) vervolgopleiding

c) elders

$r .=$ referentie

- = negatief significant effect op 5\%-niveau

$0=$ geen significant effect op $5 \%$-niveau

$+=$ positief significant effect op 5\%-niveau

1) zelfstandig werken

5) samenwerken
6) studieplanning

2) creativiteit

3) initiatief

7) informatie verzamelen en verwerken

9) rekenvaardigheden

10) computervaardigheden

4) communicatieve vaardigheden 8) taalvaardigheid

11) nauwkeurig werken

12) analytische vaardighd. 
Tabel 4c

Multivariate analyse van de kans dat schoolverlaters de vaardigheid vooral hebben geleerd in de vervolgopleiding of elders (t.o.v de VWO-opleiding)

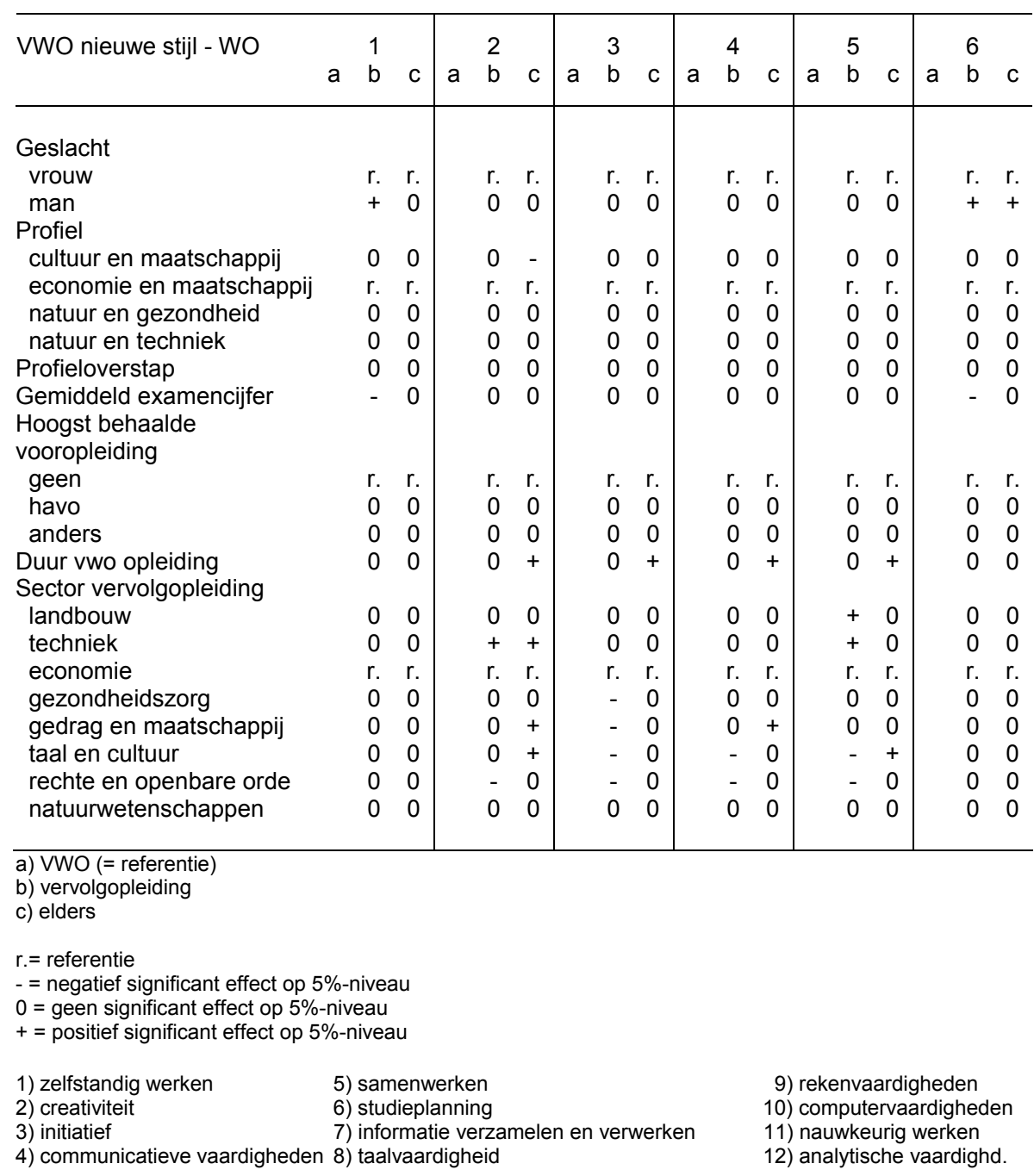


Tabel 4c. (vervolg)

\begin{tabular}{|c|c|c|c|c|c|c|c|c|c|c|c|c|c|c|c|c|c|}
\hline \multirow[t]{2}{*}{ VWO nieuwe stijl - WO } & \multicolumn{2}{|l|}{7} & \multicolumn{3}{|c|}{8} & \multicolumn{3}{|c|}{9} & \multicolumn{3}{|c|}{10} & \multicolumn{3}{|c|}{11} & \multicolumn{3}{|c|}{12} \\
\hline & $a \quad b$ & $\mathrm{C}$ & $a$ & $\mathrm{~b}$ & $\mathrm{c}$ & a & $\mathrm{b}$ & $\mathrm{c}$ & $a$ & $\mathrm{~b}$ & c & a & $\mathrm{b}$ & c & $a$ & $\mathrm{~b}$ & $\mathrm{C}$ \\
\hline \multicolumn{18}{|l|}{ Geslacht } \\
\hline vrouw & r. & $r$. & & r. & r. & & r. & r. & & r. & r. & & r. & r. & & r. & r. \\
\hline man & 0 & 0 & & 0 & 0 & & 0 & 0 & & - & + & & + & 0 & & 0 & 0 \\
\hline \multicolumn{18}{|l|}{ Profiel } \\
\hline cultuur en maatschappij & 0 & 0 & & 0 & 0 & & 0 & 0 & & 0 & 0 & & 0 & 0 & & 0 & 0 \\
\hline economie en maatschappij & r. & $r$. & & r. & r. & & r. & r. & & r. & r. & & r. & r. & & r. & r. \\
\hline natuur en gezondheid & 0 & 0 & & 0 & 0 & & - & 0 & & 0 & 0 & & 0 & 0 & & - & 0 \\
\hline natuur en techniek & 0 & + & & 0 & 0 & & 0 & 0 & & 0 & 0 & & 0 & 0 & & - & 0 \\
\hline Profieloverstap & 0 & 0 & & 0 & 0 & & 0 & 0 & & 0 & 0 & & 0 & 0 & & 0 & 0 \\
\hline $\begin{array}{l}\text { Gemiddeld examencijfer } \\
\text { Hoogst behaalde vooropleiding }\end{array}$ & 0 & 0 & & - & 0 & & 0 & 0 & & 0 & 0 & & 0 & 0 & & - & 0 \\
\hline geen & r. & $r$. & & r. & r. & & r. & r. & & r. & r. & & r. & r. & & r. & r. \\
\hline havo & 0 & 0 & & 0 & 0 & & 0 & 0 & & 0 & 0 & & 0 & 0 & & 0 & 0 \\
\hline anders & 0 & 0 & & 0 & 0 & & 0 & + & & 0 & 0 & & 0 & 0 & & - & 0 \\
\hline Duur vwo opleiding & - & 0 & & 0 & + & & 0 & + & & 0 & 0 & & 0 & 0 & & 0 & 0 \\
\hline \multicolumn{18}{|l|}{ Sector vervolgopleiding } \\
\hline landbouw & 0 & 0 & & 0 & 0 & & 0 & 0 & & 0 & 0 & & 0 & 0 & & 0 & 0 \\
\hline techniek & 0 & 0 & & 0 & 0 & & + & 0 & & + & 0 & & 0 & 0 & & 0 & 0 \\
\hline economie & r. & $r$. & & r. & r. & & r. & r. & & r. & r. & & r. & r. & & r. & r. \\
\hline gezondheidszorg & 0 & 0 & & 0 & 0 & & - & 0 & & - & 0 & & 0 & 0 & & 0 & 0 \\
\hline gedrag en maatschappij & + & 0 & & 0 & 0 & & - & 0 & & - & 0 & & + & 0 & & 0 & 0 \\
\hline taal en cultuur & + & 0 & & 0 & 0 & & - & 0 & & - & 0 & & 0 & 0 & & 0 & 0 \\
\hline rechte en openbare orde & 0 & 0 & & 0 & 0 & & - & 0 & & - & 0 & & + & 0 & & 0 & 0 \\
\hline natuurwetenschappen & 0 & 0 & & 0 & 0 & & 0 & 0 & & 0 & 0 & & + & 0 & & 0 & 0 \\
\hline
\end{tabular}

a) VWO (= referentie)

b) vervolgopleiding

c) elders

r.= referentie

- = negatief significant effect op 5\%-niveau

$0=$ geen significant effect op 5\%-niveau

$+=$ positief significant effect op $5 \%$-niveau
1) zelfstandig werken
5) samenwerken
2) creativiteit
6) studieplanning
3) initiatief
7) informatie verzamelen en verwerken
9) rekenvaardigheden
10) computervaardigheden
4) communicatieve vaardigheden 8) taalvaardigheid
11) nauwkeurig werken
12) analytische vaardighd. 
Tabel $5 a$

Multivariate analyse van de redenen van HAVO schoolverlaters voor het voortijdig verlaten van de $\mathrm{HBO}$ vervolgopleiding

\begin{tabular}{|c|c|c|c|c|c|c|}
\hline HAVO nieuwe stijl - HBO & $\begin{array}{l}\text { Onvol- } \\
\text { doende } \\
\text { gemoti- } \\
\text { veerd }\end{array}$ & $\begin{array}{l}\text { Lessen } \\
\text { niet } \\
\text { interes- } \\
\text { sant }\end{array}$ & $\begin{array}{l}\text { De } \\
\text { opleiding } \\
\text { was te } \\
\text { moeilijk }\end{array}$ & $\begin{array}{l}\text { Achteraf } \\
\text { andere } \\
\text { opleiding } \\
\text { volgen }\end{array}$ & $\begin{array}{l}\text { Wil liever } \\
\text { gaan } \\
\text { werken }\end{array}$ & Anders \\
\hline \multicolumn{7}{|l|}{ Geslacht } \\
\hline vrouw & ref. & ref. & ref. & ref. & ref. & ref. \\
\hline man & + & 0 & 0 & 0 & 0 & - \\
\hline \multicolumn{7}{|l|}{ Profiel } \\
\hline $\begin{array}{l}\text { cultuur en maatschappij } \\
\text { economie en }\end{array}$ & 0 & 0 & 0 & 0 & 0 & 0 \\
\hline maatschappij & ref. & ref. & ref. & ref. & ref. & ref. \\
\hline natuur en gezondheid & 0 & 0 & 0 & 0 & 0 & 0 \\
\hline natuur en techniek & 0 & 0 & 0 & 0 & 0 & 0 \\
\hline Profieloverstap & 0 & 0 & 0 & 0 & 0 & 0 \\
\hline $\begin{array}{l}\text { Gemiddeld examencijfer } \\
\text { Hoogst behaalde }\end{array}$ & - & 0 & - & 0 & 0 & 0 \\
\hline \multicolumn{7}{|l|}{ vooropleiding } \\
\hline geen & ref. & ref. & ref. & ref. & ref. & ref. \\
\hline mavo & 0 & 0 & 0 & 0 & 0 & 0 \\
\hline anders & 0 & 0 & 0 & 0 & 0 & 0 \\
\hline Duur havo opleiding & 0 & 0 & 0 & 0 & 0 & 0 \\
\hline \multicolumn{7}{|l|}{ Sector vervolgopleiding } \\
\hline landbouw & 0 & 0 & 0 & 0 & 0 & 0 \\
\hline onderwijs & 0 & 0 & 0 & 0 & 0 & 0 \\
\hline techniek & 0 & 0 & 0 & 0 & 0 & 0 \\
\hline economie & ref. & ref. & ref. & ref. & ref. & ref. \\
\hline gezondheidszorg & 0 & 0 & - & 0 & 0 & 0 \\
\hline gedrag en maatschappij & 0 & 0 & 0 & 0 & 0 & + \\
\hline taal en cultuur & 0 & 0 & 0 & 0 & 0 & 0 \\
\hline
\end{tabular}


Tabel $5 b$

Multivariate analyse van de redenen van VWO schoolverlaters voor het voortijdig verlaten van de $\mathrm{HBO}$ vervolgopleiding

\begin{tabular}{|c|c|c|c|c|c|c|}
\hline VWO nieuwe stijl - HBO & $\begin{array}{l}\text { Onvol- } \\
\text { doende } \\
\text { gemoti- } \\
\text { veerd }\end{array}$ & $\begin{array}{l}\text { Lessen } \\
\text { niet } \\
\text { interes- } \\
\text { sant }\end{array}$ & $\begin{array}{l}\text { De } \\
\text { opleiding } \\
\text { was te } \\
\text { moeilijk }\end{array}$ & $\begin{array}{l}\text { Achteraf } \\
\text { andere } \\
\text { opleiding } \\
\text { volgen }\end{array}$ & $\begin{array}{l}\text { Wil liever } \\
\text { gaan } \\
\text { werken }\end{array}$ & Anders \\
\hline \multicolumn{7}{|l|}{ Geslacht } \\
\hline vrouw & ref. & ref. & ref. & ref. & ref. & ref. \\
\hline man & 0 & 0 & 0 & 0 & 0 & 0 \\
\hline \multicolumn{7}{|l|}{ Profiel } \\
\hline cultuur en maatschappij & 0 & + & 0 & 0 & 0 & 0 \\
\hline economie en maatschappij & ref. & ref. & ref. & ref. & ref. & ref. \\
\hline natuur en gezondheid & 0 & + & 0 & 0 & 0 & 0 \\
\hline natuur en techniek & 0 & 0 & 0 & 0 & 0 & 0 \\
\hline Profieloverstap & 0 & 0 & 0 & 0 & 0 & 0 \\
\hline $\begin{array}{l}\text { Gemiddeld examencijfer } \\
\text { Hoogst behaalde }\end{array}$ & 0 & 0 & 0 & 0 & 0 & 0 \\
\hline \multicolumn{7}{|l|}{ vooropleiding } \\
\hline geen & ref. & ref. & ref. & ref. & ref. & ref. \\
\hline mavo & 0 & 0 & 0 & 0 & 0 & 0 \\
\hline anders & 0 & 0 & 0 & 0 & 0 & 0 \\
\hline Duur vwo opleiding & 0 & 0 & 0 & + & 0 & 0 \\
\hline \multicolumn{7}{|l|}{ Sector vervolgopleiding } \\
\hline landbouw & 0 & 0 & 0 & 0 & 0 & 0 \\
\hline onderwijs & 0 & 0 & 0 & 0 & 0 & 0 \\
\hline techniek & 0 & 0 & 0 & 0 & 0 & 0 \\
\hline economie & ref. & ref. & ref. & ref. & ref. & ref. \\
\hline gezondheidszorg & 0 & 0 & 0 & 0 & 0 & 0 \\
\hline gedrag en maatschappij & 0 & 0 & 0 & 0 & 0 & 0 \\
\hline taal en cultuur & 0 & 0 & 0 & 0 & 0 & 0 \\
\hline
\end{tabular}

ref.= referentie

- = significant negatief effect op 5\%-niveau

$0=$ geen significant effect op 5\%-niveau

$+=$ positief significant effect op $5 \%$-niveau 
Tabel $5 c$

Multivariate analyse van de redenen van VWO schoolverlaters voor het voortijdig verlaten van de WO vervolgopleiding

\begin{tabular}{|c|c|c|c|c|c|c|}
\hline VWO nieuwe stijl - WO & $\begin{array}{l}\text { Onvol- } \\
\text { doende } \\
\text { gemoti- } \\
\text { veerd }\end{array}$ & $\begin{array}{l}\text { Lessen } \\
\text { niet } \\
\text { interes- } \\
\text { sant }\end{array}$ & $\begin{array}{c}\text { De } \\
\text { opleiding } \\
\text { was te } \\
\text { moeilijk }\end{array}$ & $\begin{array}{l}\text { Achteraf } \\
\text { andere } \\
\text { opleiding } \\
\text { volgen }\end{array}$ & $\begin{array}{l}\text { Wil liever } \\
\text { gaan } \\
\text { werken }\end{array}$ & Anders \\
\hline \multicolumn{7}{|l|}{ Geslacht } \\
\hline vrouw & ref. & ref. & ref. & ref. & ref. & ref. \\
\hline man & 0 & 0 & 0 & 0 & 0 & 0 \\
\hline \multicolumn{7}{|l|}{ Profiel } \\
\hline cultuur en maatschappij & 0 & 0 & 0 & - & 0 & 0 \\
\hline economie en maatschappij & ref. & ref. & ref. & ref. & ref. & ref. \\
\hline natuur en gezondheid & 0 & 0 & 0 & 0 & 0 & 0 \\
\hline natuur en techniek & 0 & 0 & 0 & 0 & 0 & 0 \\
\hline Profieloverstap & 0 & 0 & 0 & 0 & 0 & 0 \\
\hline $\begin{array}{l}\text { Gemiddeld examencijfer } \\
\text { Hoogst behaalde }\end{array}$ & 0 & 0 & - & 0 & 0 & 0 \\
\hline \multicolumn{7}{|l|}{ vooropleiding } \\
\hline geen & ref. & ref. & ref. & ref. & ref. & ref. \\
\hline havo & 0 & 0 & 0 & 0 & 0 & 0 \\
\hline anders & 0 & 0 & 0 & 0 & 0 & 0 \\
\hline Duur vwo opleiding & 0 & 0 & 0 & 0 & 0 & 0 \\
\hline \multicolumn{7}{|l|}{ Sector vervolgopleiding } \\
\hline landbouw & 0 & 0 & 0 & 0 & 0 & 0 \\
\hline techniek & 0 & 0 & 0 & 0 & 0 & 0 \\
\hline economie & ref. & ref. & ref. & ref. & ref. & ref. \\
\hline gezondheidszorg & 0 & - & 0 & 0 & 0 & 0 \\
\hline gedrag en maatschappij & - & - & - & 0 & 0 & 0 \\
\hline taal en cultuur & 0 & 0 & - & 0 & 0 & 0 \\
\hline recht en openbare orde & 0 & - & - & 0 & 0 & 0 \\
\hline natuurwetenschappen & 0 & - & 0 & 0 & 0 & 0 \\
\hline
\end{tabular}

ref.= referentie

- = significant negatief effect op 5\%-niveau

$0=$ geen significant effect op 5\%-niveau

$+=$ positief significant effect op $5 \%$-niveau 
Tabel 6

Aandeel HAVO/VWO-schoolverlaters dat informatie over de studie- en beroepskeuze heeft gekregen, naar profiel

$\begin{array}{lllllllll}1 & 2 & 3 & 4 & 5 & 6 & 7 & 8 & 9\end{array}$

\section{HAVO nieuwe stijl - HBO}

cultuur en maatschappij

economie en maatschappij

natuur en gezondheid

natuur en techniek

$\begin{array}{lllllllll}98 & 99 & 98 & 96 & 76 & 78 & 79 & 89 & 80 \\ 98 & 98 & 98 & 96 & 79 & 83 & 83 & 91 & 83 \\ 98 & 98 & 98 & 95 & 73 & 78 & 80 & 89 & 79 \\ 97 & 97 & 98 & 94 & 77 & 83 & 85 & 91 & 84\end{array}$

VWO nieuwe stijl - HBO

cultuur en maatschappij

economie en maatschappij

natuur en gezondheid

$\begin{array}{ccccccccc}100 & 99 & 99 & 98 & 74 & 75 & 78 & 91 & 84 \\ 98 & 99 & 98 & 97 & 78 & 82 & 81 & 90 & 80 \\ 97 & 98 & 99 & 99 & 75 & 79 & 81 & 87 & 78 \\ 100 & 100 & 100 & 98 & 78 & 80 & 86 & 90 & 85\end{array}$

natuur en techniek

VWO nieuwe stijl - WO

cultuur en maatschappi

economie en maatschappi

$\begin{array}{lllllllll}98 & 99 & 98 & 97 & 79 & 84 & 82 & 88 & 84\end{array}$

natuur en gezondheid

$\begin{array}{cc}98 & 98 \\ 100 & 99\end{array}$

natuur en techniek

$100 \quad 99$

antwoordcategorieën: 1) goed 2) redelijk 3) matig 4) slecht 5) geen informatie gehad

In de tabel is het aandeel schoolverlaters vermeld dat de informatie heeft gekregen (antwoordcategorie 1, 2, 3

of 4)

1) informatie over de mogelijkheden van verschillende vakkenpakketten

2) informatie bij de keuze van een vakkenpakket

3) informatie over vervolgopleidingen

4) informatie over de hulp bij het kiezen van vervolgopleidingen

5 ) informatie over de inhoud van de lessen op de vervolgopleiding

6 ) informatie over de manier waarop les wordt gegeven op de vervolgopleiding

7) informatie over de moeilijkheidsgraad van de vervolgopleiding

8 ) informatie over de beroepen die je met een vervolgopleiding kunt uitoefenen

9 ) informatie over de kans op werk met vervolgopleiding 
Tabel 7a

Multivariate analyse van de kans dat schoolverlaters informatie over de studie- en beroepskeuze hebben gekregen

\begin{tabular}{|c|c|c|c|c|c|c|c|c|c|}
\hline HAVO nieuwe stijl - HBO & 1 & 2 & 3 & 4 & 5 & 6 & 7 & 8 & 9 \\
\hline \multicolumn{10}{|l|}{ Geslacht } \\
\hline vrouw & \multicolumn{9}{|c|}{ referentie } \\
\hline man & 0 & 0 & 0 & 0 & 0 & 0 & 0 & 0 & 0 \\
\hline \multicolumn{10}{|l|}{ Profiel } \\
\hline $\begin{array}{l}\text { cultuur en maatschappij } \\
\text { economie en maatschappij }\end{array}$ & 0 & 0 & \multicolumn{5}{|c|}{ referentie } & 0 & 0 \\
\hline natuur en gezondheid & 0 & 0 & 0 & 0 & 0 & 0 & 0 & 0 & 0 \\
\hline natuur en techniek & 0 & 0 & 0 & - & 0 & 0 & 0 & 0 & 0 \\
\hline Profieloverstap & 0 & - & 0 & 0 & 0 & 0 & 0 & 0 & 0 \\
\hline Gemiddeld examencijfer & 0 & 0 & 0 & 0 & 0 & 0 & 0 & 0 & 0 \\
\hline geen & \multicolumn{9}{|c|}{ referentie } \\
\hline mavo & 0 & 0 & 0 & 0 & 0 & 0 & 0 & 0 & 0 \\
\hline anders & 0 & 0 & 0 & 0 & 0 & 0 & 0 & 0 & 0 \\
\hline Duur havo opleiding & 0 & 0 & 0 & 0 & - & 0 & 0 & - & 0 \\
\hline \multicolumn{10}{|l|}{ Sector vervolgopleiding } \\
\hline landbouw & 0 & 0 & 0 & 0 & 0 & 0 & - & - & 0 \\
\hline onderwijs & 0 & 0 & 0 & + & 0 & 0 & 0 & + & + \\
\hline techniek & 0 & 0 & 0 & 0 & 0 & 0 & 0 & 0 & 0 \\
\hline economie & \multicolumn{9}{|c|}{ referentie } \\
\hline gezondheidszorg & 0 & 0 & 0 & 0 & 0 & 0 & 0 & 0 & 0 \\
\hline gedrag en maatschappij & 0 & 0 & 0 & 0 & - & 0 & 0 & 0 & - \\
\hline taal en cultuur & 0 & 0 & 0 & 0 & 0 & 0 & 0 & 0 & 0 \\
\hline
\end{tabular}

- = negatief significant effect op 5\%-niveau

$0=$ geen significant effect op $5 \%$-niveau

$+=$ positief significant effect op $5 \%$-niveau

1) informatie over de mogelijkheden van verschillende vakkenpakketten

2) informatie bij de keuze van een vakkenpakket

3) informatie over vervolgopleidingen

4) informatie over de hulp bij het kiezen van vervolgopleidingen

5) informatie over de inhoud van de lessen op de vervolgopleiding

6) informatie over de manier waarop les wordt gegeven op de vervolgopleiding

7) informatie over de moeilijkheidsgraad van de vervolgopleiding

8 ) informatie over de beroepen die je met een vervolgopleiding kunt uitoefenen

9) informatie over de kans op werk met vervolgopleiding 
Tabel $7 b$

Multivariate analyse van de kans dat schoolverlaters informatie over de studie- en beroepskeuze hebben gekregen

\begin{tabular}{|c|c|c|c|c|c|c|c|c|c|}
\hline VWO nieuwe stijl - HBO & 1 & 2 & 3 & 4 & 5 & 6 & 7 & 8 & 9 \\
\hline \multicolumn{10}{|l|}{ Geslacht } \\
\hline vrouw & \multicolumn{9}{|c|}{ referentie } \\
\hline man & 0 & 0 & 0 & 0 & 0 & 0 & + & 0 & 0 \\
\hline Profiel & & & & & & & & & \\
\hline cultuur en maatschappij & 0 & 0 & 0 & 0 & 0 & 0 & 0 & 0 & 0 \\
\hline economie en maatschappij & \multicolumn{9}{|c|}{ referentie } \\
\hline natuur en gezondheid & 0 & 0 & 0 & 0 & 0 & 0 & 0 & 0 & 0 \\
\hline natuur en techniek & 0 & 0 & 0 & 0 & 0 & 0 & 0 & 0 & 0 \\
\hline Profieloverstap & 0 & 0 & 0 & 0 & 0 & 0 & 0 & 0 & 0 \\
\hline Gemiddeld examencijfer & 0 & 0 & 0 & 0 & 0 & 0 & 0 & 0 & 0 \\
\hline $\begin{array}{l}\text { Hoogst behaalde vooropleiding } \\
\text { geen }\end{array}$ & \multicolumn{9}{|c|}{ referentie } \\
\hline havo & 0 & 0 & 0 & 0 & 0 & 0 & 0 & 0 & 0 \\
\hline anders & 0 & 0 & 0 & 0 & 0 & 0 & 0 & 0 & 0 \\
\hline Duur vwo opleiding & 0 & 0 & 0 & 0 & 0 & 0 & 0 & 0 & 0 \\
\hline \multicolumn{10}{|l|}{ Sector vervolgopleiding } \\
\hline landbouw & 0 & 0 & 0 & 0 & 0 & 0 & 0 & 0 & 0 \\
\hline onderwijs & 0 & 0 & 0 & 0 & 0 & 0 & 0 & 0 & 0 \\
\hline techniek & 0 & 0 & 0 & 0 & 0 & 0 & 0 & 0 & 0 \\
\hline economie & \multicolumn{9}{|c|}{ referentie } \\
\hline gezondheidszorg & 0 & 0 & 0 & 0 & 0 & 0 & 0 & 0 & 0 \\
\hline gedrag en maatschappij & 0 & 0 & 0 & 0 & - & - & 0 & 0 & - \\
\hline taal en cultuur & 0 & 0 & 0 & 0 & 0 & 0 & 0 & - & 0 \\
\hline
\end{tabular}

- = negatief significant effect op 5\%-niveau

$0=$ geen significant effect op $5 \%$-niveau

$+=$ positief significant effect op $5 \%$-niveau

1) informatie over de mogelijkheden van verschillende vakkenpakketten

2) informatie bij de keuze van een vakkenpakket

3) informatie over vervolgopleidingen

4) informatie over de hulp bij het kiezen van vervolgopleidingen

5) informatie over de inhoud van de lessen op de vervolgopleiding

6 ) informatie over de manier waarop les wordt gegeven op de vervolgopleiding

7) informatie over de moeilijkheidsgraad van de vervolgopleiding

8 ) informatie over de beroepen die je met een vervolgopleiding kunt uitoefenen

9) informatie over de kans op werk met vervolgopleiding 
Tabel 7c

Multivariate analyse van de kans dat schoolverlaters informatie over de studie- en beroepskeuze hebben gekregen

\begin{tabular}{|c|c|c|c|c|c|c|c|c|c|}
\hline VWO nieuwe stijl - WO & 1 & 2 & 3 & 4 & 5 & 6 & 7 & 8 & 9 \\
\hline \multicolumn{10}{|l|}{ Geslacht } \\
\hline vrouw & \multicolumn{9}{|c|}{ referentie } \\
\hline man & 0 & 0 & 0 & 0 & 0 & 0 & - & 0 & 0 \\
\hline \multicolumn{10}{|l|}{ Profiel } \\
\hline cultuur en maatschappij & 0 & 0 & 0 & 0 & 0 & 0 & 0 & 0 & 0 \\
\hline economie en maatschappij & \multicolumn{9}{|c|}{ referentie } \\
\hline natuur en gezondheid & 0 & 0 & 0 & 0 & 0 & 0 & 0 & 0 & 0 \\
\hline natuur en techniek & 0 & 0 & 0 & 0 & 0 & 0 & 0 & + & 0 \\
\hline Profieloverstap & 0 & 0 & 0 & 0 & 0 & 0 & 0 & 0 & 0 \\
\hline Gemiddeld examencijfer & 0 & 0 & 0 & 0 & 0 & 0 & 0 & 0 & 0 \\
\hline $\begin{array}{l}\text { Hoogst behaalde vooropleiding } \\
\text { geen }\end{array}$ & \multicolumn{9}{|c|}{ referentie } \\
\hline havo & 0 & 0 & 0 & 0 & 0 & 0 & 0 & 0 & 0 \\
\hline anders & 0 & 0 & 0 & 0 & 0 & 0 & 0 & 0 & 0 \\
\hline Duur vwo opleiding & 0 & 0 & 0 & 0 & 0 & 0 & 0 & 0 & 0 \\
\hline \multicolumn{10}{|l|}{ Sector vervolgopleiding } \\
\hline landbouw & 0 & 0 & 0 & 0 & 0 & 0 & 0 & 0 & 0 \\
\hline techniek & 0 & 0 & 0 & 0 & 0 & 0 & 0 & 0 & 0 \\
\hline economie & \multicolumn{9}{|c|}{ referentie } \\
\hline gezondheidszorg & 0 & 0 & 0 & 0 & 0 & 0 & 0 & + & 0 \\
\hline gedrag en maatschappij & 0 & 0 & 0 & 0 & 0 & 0 & 0 & 0 & - \\
\hline taal en cultuur & 0 & - & 0 & 0 & 0 & 0 & 0 & 0 & 0 \\
\hline recht en openbare orde & 0 & 0 & 0 & 0 & 0 & 0 & 0 & + & 0 \\
\hline natuurwetenschappen & 0 & 0 & 0 & 0 & - & - & - & 0 & 0 \\
\hline
\end{tabular}

- = negatief significant effect op 5\%-niveau

$0=$ geen significant effect op $5 \%$-niveau

$+=$ positief significant effect op $5 \%$-niveau

1) informatie over de mogelijkheden van verschillende vakkenpakketten

2) informatie bij de keuze van een vakkenpakket

3 ) informatie over vervolgopleidingen

4) informatie over de hulp bij het kiezen van vervolgopleidingen

5 ) informatie over de inhoud van de lessen op de vervolgopleiding

6 ) informatie over de manier waarop les wordt gegeven op de vervolgopleiding

7) informatie over de moeilijkheidsgraad van de vervolgopleiding

8) informatie over de beroepen die je met een vervolgopleiding kunt uitoefenen

9) informatie over de kans op werk met vervolgopleiding 
Tabel 8

Gemiddelde kwaliteitscores HAVO/VWO-schoolverlaters informatie over de studie- en beroepskeuze, naar profiel $^{1}$

$\begin{array}{lllllllll}1 & 2 & 3 & 4 & 5 & 6 & 7 & 8 & 9\end{array}$

HAVO nieuwe stijl - HBO cultuur en maatschappi economie en maatschappij natuur en gezondheid natuur en techniek

$\begin{array}{lllllllll}3,1 & 3,0 & 2,7 & 2,7 & 2,1 & 2,3 & 2,4 & 2,9 & 2,7 \\ 3,0 & 2,9 & 2,6 & 2,5 & 2,0 & 2,2 & 2,3 & 2,6 & 2,6 \\ 3,2 & 3,1 & 2,7 & 2,6 & 2,1 & 2,2 & 2,4 & 2,9 & 2,9 \\ 3,0 & 2,9 & 2,5 & 2,5 & 2,0 & 2,1 & 2,2 & 2,6 & 2,6\end{array}$

VWO nieuwe stijl - HBO cultuur en maatschappij economie en maatschappij natuur en gezondheid

$\begin{array}{lllllllll}3,1 & 3,0 & 2,8 & 2,6 & 2,1 & 2,4 & 2,5 & 2,8 & 2,7 \\ 3,1 & 3,0 & 2,7 & 2,6 & 2,2 & 2,4 & 2,4 & 2,8 & 2,7 \\ 3,3 & 3,2 & 2,9 & 2,7 & 2,3 & 2,3 & 2,5 & 2,9 & 2,7 \\ 3,1 & 3,1 & 2,9 & 2,6 & 2,2 & 2,3 & 2,4 & 2,8 & 2,8\end{array}$
natuur en techniek

VWO nieuwe stijl - WO

cultuur en maatschappij economie en maatschappij

$3,2 \quad 3,1 \quad 2,9 \quad 2,7 \quad 2,2$
natuur en gezondheid

${ }^{1}$ De kwaliteitscores zijn bepaald aan de hand van de vraag over de kwaliteit van negen verschillende informatiebronnen (antwoordcategorieën goed, redelijk, matig slecht). Voor de bepaling van de gemiddelde score zijn de volgende waarden aan de betreffende antwoordcategorieën toegekend; goed=4, redelijk=3, matig $=2$, slecht $=1$

1) informatie over de mogelijkheden van verschillende vakkenpakketten

2) informatie bij de keuze van een vakkenpakket

3 ) informatie over vervolgopleidingen

4) informatie over de hulp bij het kiezen van vervolgopleidingen

5 ) informatie over de inhoud van de lessen op de vervolgopleiding

6 ) informatie over de manier waarop les wordt gegeven op de vervolgopleiding

7) informatie over de moeilijkheidsgraad van de vervolgopleiding

8) informatie over de beroepen die je met een vervolgopleiding kunt uitoefenen

9 ) informatie over de kans op werk met vervolgopleiding 
Tabel 9a

Multivariate analyse van de kwaliteitsscores van de informatie over de studie- en beroepskeuze

\begin{tabular}{|c|c|c|c|c|c|c|c|c|c|}
\hline HAVO nieuwe stijl - HBO & 1 & 2 & 3 & 4 & 5 & 6 & 7 & 8 & 9 \\
\hline \multicolumn{10}{|l|}{ Geslacht } \\
\hline vrouw & \multicolumn{9}{|c|}{ referentie } \\
\hline man & - & 0 & - & - & 0 & 0 & 0 & - & 0 \\
\hline \multicolumn{10}{|l|}{ Profiel } \\
\hline $\begin{array}{l}\text { cultuur en maatschappij } \\
\text { economie en maatschappij }\end{array}$ & 0 & 0 & 0 & 0 & $\begin{array}{l}0 \\
\text { ere }\end{array}$ & 0 & 0 & 0 & 0 \\
\hline natuur en gezondheid & + & + & 0 & 0 & 0 & 0 & 0 & + & + \\
\hline natuur en techniek & 0 & 0 & 0 & 0 & 0 & 0 & 0 & 0 & 0 \\
\hline Profieloverstap & - & 0 & 0 & 0 & 0 & 0 & 0 & 0 & 0 \\
\hline Gemiddeld examencijfer & 0 & + & 0 & 0 & 0 & 0 & 0 & 0 & 0 \\
\hline $\begin{array}{l}\text { Hoogst behaalde vooropleiding } \\
\text { geen }\end{array}$ & \multicolumn{9}{|c|}{ referentie } \\
\hline mavo & 0 & 0 & 0 & 0 & 0 & 0 & 0 & 0 & 0 \\
\hline anders & 0 & 0 & 0 & 0 & 0 & 0 & 0 & 0 & 0 \\
\hline Duur havo opleiding & - & - & 0 & - & 0 & 0 & 0 & 0 & 0 \\
\hline \multicolumn{10}{|l|}{ Sector vervolgopleiding } \\
\hline landbouw & 0 & 0 & 0 & 0 & 0 & 0 & 0 & 0 & 0 \\
\hline onderwijs & 0 & 0 & + & + & 0 & 0 & 0 & + & + \\
\hline techniek & 0 & 0 & 0 & + & 0 & 0 & 0 & 0 & 0 \\
\hline economie & \multicolumn{9}{|c|}{ referentie } \\
\hline gezondheidszorg & 0 & 0 & + & + & 0 & 0 & + & + & + \\
\hline gedrag en maatschappij & 0 & 0 & 0 & 0 & 0 & 0 & 0 & 0 & 0 \\
\hline taal en cultuur & 0 & 0 & 0 & 0 & 0 & 0 & 0 & 0 & 0 \\
\hline
\end{tabular}

${ }^{1}$ De kwaliteitscores zijn bepaald aan de hand van de vraag over de kwaliteit van negen verschillende informatiebronnen (antwoordcategorieën goed, redelijk, matig slecht). Voor de bepaling van de gemiddelde score zijn de volgende waarden aan de betreffende antwoordcategorieën toegekend; goed=4, redelijk=3, matig $=2$, slecht $=1$

- = negatief significant effect op 5\%-niveau

$0=$ geen significant effect op $5 \%$-niveau

$+=$ positief significant effect op $5 \%$-niveau

1) informatie over de mogelijkheden van verschillende vakkenpakketten

2) informatie bij de keuze van een vakkenpakket

3) informatie over vervolgopleidingen

4) informatie over de hulp bij het kiezen van vervolgopleidingen

5 ) informatie over de inhoud van de lessen op de vervolgopleiding

6 ) informatie over de manier waarop les wordt gegeven op de vervolgopleiding

7) informatie over de moeilijkheidsgraad van de vervolgopleiding

8) informatie over de beroepen die je met een vervolgopleiding kunt uitoefenen

9) informatie over de kans op werk met vervolgopleiding 
Tabel $9 b$

Multivariate analyse van de kwaliteitsscores van de informatie over de studie- en beroepskeuze

\begin{tabular}{|c|c|c|c|c|c|c|c|c|c|}
\hline VWO nieuwe stijl - HBO & 1 & 2 & 3 & 4 & 5 & 6 & 7 & 8 & 9 \\
\hline \multicolumn{10}{|l|}{ Geslacht } \\
\hline vrouw & \multicolumn{9}{|c|}{ referentie } \\
\hline man & 0 & 0 & 0 & 0 & 0 & 0 & 0 & 0 & 0 \\
\hline \multicolumn{10}{|l|}{ Profiel } \\
\hline $\begin{array}{l}\text { cultuur en maatschappij } \\
\text { economie en maatschappij }\end{array}$ & 0 & 0 & \multicolumn{6}{|c|}{ referentie } & 0 \\
\hline natuur en gezondheid & + & + & 0 & 0 & 0 & 0 & 0 & 0 & 0 \\
\hline natuur en techniek & 0 & 0 & 0 & 0 & 0 & 0 & 0 & 0 & 0 \\
\hline Profieloverstap & 0 & - & 0 & 0 & 0 & 0 & 0 & 0 & 0 \\
\hline $\begin{array}{l}\text { Gemiddeld examencijfer } \\
\text { Hoogst behaalde vooropleiding }\end{array}$ & 0 & 0 & 0 & 0 & 0 & 0 & 0 & 0 & 0 \\
\hline geen & \multicolumn{9}{|c|}{ referentie } \\
\hline havo & 0 & 0 & 0 & 0 & 0 & 0 & 0 & 0 & 0 \\
\hline anders & 0 & 0 & 0 & 0 & 0 & 0 & 0 & 0 & 0 \\
\hline Duur vwo opleiding & 0 & - & 0 & 0 & 0 & 0 & 0 & 0 & 0 \\
\hline \multicolumn{10}{|l|}{ Sector vervolgopleiding } \\
\hline landbouw & 0 & 0 & 0 & 0 & 0 & 0 & 0 & 0 & 0 \\
\hline onderwijs & 0 & 0 & 0 & 0 & 0 & 0 & 0 & + & + \\
\hline techniek & 0 & 0 & 0 & 0 & 0 & 0 & 0 & 0 & 0 \\
\hline economie & \multicolumn{9}{|c|}{ referentie } \\
\hline gezondheidszorg & 0 & 0 & + & + & 0 & 0 & 0 & + & 0 \\
\hline gedrag en maatschappij & 0 & 0 & 0 & 0 & 0 & 0 & 0 & 0 & 0 \\
\hline taal en cultuur & 0 & 0 & 0 & 0 & 0 & 0 & 0 & 0 & 0 \\
\hline
\end{tabular}

${ }^{1}$ De kwaliteitscores zijn bepaald aan de hand van de vraag over de kwaliteit van negen verschillende informatiebronnen (antwoordcategorieën goed, redelijk, matig slecht). Voor de bepaling van de gemiddelde score zijn de volgende waarden aan de betreffende antwoordcategorieën toegekend; goed=4, redelijk=3, matig $=2$, slecht $=1$

- = negatief significant effect op 5\%-niveau

$0=$ geen significant effect op $5 \%$-niveau

$+=$ positief significant effect op 5\%-niveau

1) informatie over de mogelijkheden van verschillende vakkenpakketten

2) informatie bij de keuze van een vakkenpakket

3) informatie over vervolgopleidingen

4) informatie over de hulp bij het kiezen van vervolgopleidingen

5 ) informatie over de inhoud van de lessen op de vervolgopleiding

6 ) informatie over de manier waarop les wordt gegeven op de vervolgopleiding

7) informatie over de moeilijkheidsgraad van de vervolgopleiding

8 ) informatie over de beroepen die je met een vervolgopleiding kunt uitoefenen

9) informatie over de kans op werk met vervolgopleiding 
Tabel 9c

Multivariate analyse van de kwaliteitsscores van de informatie over de studie- en beroepskeuze

\begin{tabular}{|c|c|c|c|c|c|c|c|c|c|}
\hline VWO nieuwe stijl - WO & 1 & 2 & 3 & 4 & 5 & 6 & 7 & 8 & 9 \\
\hline \multicolumn{10}{|l|}{ Geslacht } \\
\hline vrouw & \multicolumn{9}{|c|}{ referentie } \\
\hline man & - & 0 & - & 0 & 0 & 0 & 0 & 0 & 0 \\
\hline \multicolumn{10}{|l|}{ Profiel } \\
\hline cultuur en maatschappij & 0 & 0 & 0 & 0 & 0 & 0 & 0 & 0 & 0 \\
\hline economie en maatschappij & \multicolumn{9}{|c|}{ referentie } \\
\hline natuur en gezondheid & 0 & 0 & 0 & 0 & 0 & 0 & 0 & 0 & 0 \\
\hline natuur en techniek & 0 & 0 & 0 & 0 & + & 0 & + & 0 & 0 \\
\hline Profieloverstap & 0 & - & 0 & 0 & 0 & 0 & + & 0 & 0 \\
\hline Gemiddeld examencijfer & + & + & 0 & + & 0 & + & + & + & 0 \\
\hline $\begin{array}{l}\text { Hoogst behaalde vooropleiding } \\
\text { geen }\end{array}$ & \multicolumn{9}{|c|}{ referentie } \\
\hline havo & 0 & 0 & + & + & 0 & 0 & 0 & 0 & 0 \\
\hline anders & 0 & 0 & 0 & 0 & 0 & 0 & + & 0 & 0 \\
\hline Duur vwo opleiding & 0 & - & 0 & 0 & 0 & 0 & 0 & 0 & 0 \\
\hline \multicolumn{10}{|l|}{ Sector vervolgopleiding } \\
\hline landbouw & 0 & 0 & 0 & 0 & 0 & 0 & 0 & 0 & 0 \\
\hline techniek & + & 0 & 0 & 0 & 0 & 0 & 0 & 0 & 0 \\
\hline economie & \multicolumn{9}{|c|}{ referentie } \\
\hline gezondheidszorg & 0 & 0 & 0 & 0 & 0 & 0 & 0 & + & 0 \\
\hline gedrag en maatschappij & 0 & 0 & 0 & 0 & 0 & 0 & 0 & 0 & - \\
\hline taal en cultuur & 0 & 0 & 0 & 0 & 0 & - & 0 & 0 & - \\
\hline recht en openbare orde & 0 & 0 & 0 & 0 & 0 & 0 & - & 0 & - \\
\hline natuurwetenschappen & 0 & 0 & 0 & 0 & 0 & 0 & 0 & - & - \\
\hline
\end{tabular}

${ }^{1}$ De kwaliteitscores zijn bepaald aan de hand van de vraag over de kwaliteit van negen verschillende informatiebronnen (antwoordcategorieën goed, redelijk, matig slecht). Voor de bepaling van de gemiddelde score zijn de volgende waarden aan de betreffende antwoord-categorieën toegekend; goed=4, redelijk=3, matig $=2$, slecht $=1$

- = negatief significant effect op 5\%-niveau

$0=$ geen significant effect op $5 \%$-niveau

$+=$ positief significant effect op $5 \%$-niveau

1) informatie over de mogelijkheden van verschillende vakkenpakketten

2) informatie bij de keuze van een vakkenpakket

3) informatie over vervolgopleidingen

4) informatie over de hulp bij het kiezen van vervolgopleidingen

5 ) informatie over de inhoud van de lessen op de vervolgopleiding

6 ) informatie over de manier waarop les wordt gegeven op de vervolgopleiding

7) informatie over de moeilijkheidsgraad van de vervolgopleiding

8) informatie over de beroepen die je met een vervolgopleiding kunt uitoefenen

9) informatie over de kans op werk met vervolgopleiding 
Tabel 10

Aandeel HAVO/VWO-schoolverlaters dat gebruik heeft gemaakt van de betreffende informatiebron, naar profiel $^{*}$

\begin{tabular}{|c|c|c|c|c|}
\hline $\begin{array}{c}\text { Begelei- } \\
\text { ding op } \\
\text { school }\end{array}$ & $\begin{array}{c}\text { Open- } \\
\text { dagen } \\
\text { vervolg- } \\
\text { opleiding }\end{array}$ & $\begin{array}{l}\text { Meeloop- } \\
\text { dagen } \\
\text { vervolg- } \\
\text { opleiding }\end{array}$ & Folders & $\begin{array}{c}\text { Compu- } \\
\text { ters/ } \\
\text { internet }\end{array}$ \\
\hline
\end{tabular}

HAVO nieuwe stijl - HBO

cultuur en maatschappij

economie en maatschappij

natuur en gezondheid

46
53

natuur en techniek

$49 \quad 88$

$\begin{array}{lllll}88 & 33 & 68 & 60 & 20 \\ 86 & 26 & 66 & 62 & 17 \\ 83 & 36 & 69 & 60 & 21 \\ 88 & 31 & 62 & 64 & 14\end{array}$

\section{VWO nieuwe stijl - HBO}

cultuur en maatschappij

economie en maatschappij

natuur en gezondheid

$54 \quad 91$

natuur en techniek

$49 \quad 88$

$49 \quad 90$

$40 \quad 91$

30
36
27
29

75

$64 \quad 27$

VWO nieuwe stijl - WO

cultuur en maatschappij

economie en maatschappij

$57 \quad 91$

natuur en gezondheid

$53-91$

natuur en techniek

$\begin{array}{ll}38 & 84 \\ 40 & 81 \\ 39 & 79 \\ 44 & 77\end{array}$

$\begin{array}{lll}80 & 65 & 24 \\ 74 & 68 & 15\end{array}$

* meerdere antwoorden mogelijk 
Tabel 11

Informatiebron die HAVO/VWO-schoolverlaters het nuttigst vinden bij de studie- beroepskeuze, naar profiel $^{*}$

$\begin{array}{ccccc}\text { Begelei- } & \text { Open- } & \text { Meeloop- } & \text { Folders } & \text { Compu- } \\ \text { ding op } & \text { dagen } & \text { dagen } & \text { Anders } \\ \text { school } & \begin{array}{c}\text { vervolg- } \\ \text { vervolg- }\end{array} & \text { internet } & \\ & \text { opleiding } & \text { opleiding } & & \end{array}$

\begin{tabular}{|c|c|c|c|c|c|c|}
\hline HAVO nieuwe stijl - HBO & 6 & 52 & 20 & 7 & 9 & 7 \\
\hline VWO nieuwe stijl - HBO & 4 & 48 & 18 & 11 & 8 & 11 \\
\hline VWO nieuwe stijl - WO & 4 & 47 & 24 & 12 & 9 & 4 \\
\hline \multicolumn{7}{|l|}{ economie en maatschappij } \\
\hline HAVO nieuwe stijl - HBO & 7 & 49 & 15 & 10 & 12 & 7 \\
\hline VWO nieuwe stijl - HBO & 5 & 46 & 18 & 10 & 10 & 10 \\
\hline VWO nieuwe stijl - WO & 5 & 43 & 24 & 13 & 10 & 6 \\
\hline \multicolumn{7}{|l|}{ natuur en gezondheid } \\
\hline HAVO nieuwe stijl - HBO & 5 & 49 & 21 & 8 & 10 & 8 \\
\hline VWO nieuwe stijl - HBO & 6 & 50 & 17 & 10 & 9 & 9 \\
\hline VWO nieuwe stijl - WO & 4 & 49 & 21 & 10 & 8 & 7 \\
\hline \multicolumn{7}{|l|}{ natuur en techniek } \\
\hline HAVO nieuwe stijl - HBO & 7 & 47 & 18 & 7 & 12 & 9 \\
\hline VWO nieuwe stijl - HBO & 3 & 48 & 23 & 7 & 14 & 5 \\
\hline VWO nieuwe stijl - WO & 4 & 47 & 28 & 7 & 9 & 5 \\
\hline
\end{tabular}

* Eén antwoord mogelijk 
Tabel $12 a$

Multivariate analyse van de kans dat schoolverlaters gebruik maken van de betreffende informatiebron

\begin{tabular}{|c|c|c|c|c|c|c|}
\hline HAVO nieuwe stijl - HBO & $\begin{array}{l}\text { Begelei- } \\
\text { ding op } \\
\text { school }\end{array}$ & $\begin{array}{c}\text { Open- } \\
\text { dagen } \\
\text { vervolg- } \\
\text { opleiding }\end{array}$ & $\begin{array}{l}\text { Meeloop- } \\
\text { dagen } \\
\text { vervolg- } \\
\text { opleiding }\end{array}$ & Folders & $\begin{array}{c}\text { Compu- } \\
\text { ters/ } \\
\text { internet }\end{array}$ & Anders \\
\hline \multicolumn{7}{|l|}{ Geslacht } \\
\hline vrouw & ref. & ref. & ref. & ref. & ref. & ref. \\
\hline man & 0 & - & - & 0 & 0 & 0 \\
\hline \multicolumn{7}{|l|}{ Profiel } \\
\hline cultuur en maatschappij & 0 & 0 & 0 & 0 & 0 & + \\
\hline economie en maatschappij & ref. & ref. & ref. & ref. & ref. & ref. \\
\hline natuur en gezondheid & + & 0 & 0 & 0 & 0 & 0 \\
\hline natuur en techniek & 0 & 0 & + & 0 & 0 & 0 \\
\hline Profieloverstap & 0 & 0 & 0 & 0 & 0 & 0 \\
\hline Gemiddeld examencijfer & + & 0 & 0 & 0 & 0 & 0 \\
\hline \multicolumn{7}{|l|}{ Hoogst behaalde vooropleiding } \\
\hline geen & ref. & ref. & ref. & ref. & ref. & ref. \\
\hline mavo & 0 & 0 & 0 & 0 & 0 & 0 \\
\hline anders & 0 & 0 & 0 & 0 & 0 & 0 \\
\hline Duur havo opleiding & 0 & - & - & 0 & + & 0 \\
\hline \multicolumn{7}{|l|}{ Sector vervolgopleiding } \\
\hline landbouw & 0 & 0 & + & 0 & - & 0 \\
\hline onderwijs & 0 & 0 & + & - & - & 0 \\
\hline techniek & 0 & 0 & 0 & 0 & 0 & 0 \\
\hline economie & ref. & ref. & ref. & ref. & ref. & ref. \\
\hline gezondheidszorg & 0 & 0 & 0 & 0 & 0 & 0 \\
\hline gedrag en maatschappij & 0 & 0 & 0 & 0 & 0 & + \\
\hline taal en cultuur & 0 & 0 & 0 & 0 & 0 & 0 \\
\hline
\end{tabular}

ref. = referentie

- = negatief significant effect op 5\%-niveau

$0=$ geen significant effect op $5 \%$-niveau

$+=$ positief significant effect op $5 \%$-niveau 
Tabel $12 b$

Multivariate analyse van de kans dat schoolverlaters gebruik maken van de betreffende informatiebron

\begin{tabular}{|c|c|c|c|c|c|c|}
\hline HAVO nieuwe stijl - WO & $\begin{array}{l}\text { Begelei- } \\
\text { ding op } \\
\text { school }\end{array}$ & $\begin{array}{c}\text { Open- } \\
\text { dagen } \\
\text { vervolg- } \\
\text { opleiding }\end{array}$ & $\begin{array}{l}\text { Meeloop- } \\
\text { dagen } \\
\text { vervolg- } \\
\text { opleiding }\end{array}$ & Folders & $\begin{array}{c}\text { Compu- } \\
\text { ters/ } \\
\text { internet }\end{array}$ & Anders \\
\hline \multicolumn{7}{|l|}{ Geslacht } \\
\hline vrouw & ref. & ref. & ref. & ref. & ref. & ref. \\
\hline man & 0 & 0 & 0 & 0 & 0 & 0 \\
\hline \multicolumn{7}{|l|}{ Profiel } \\
\hline cultuur en maatschappij & 0 & 0 & 0 & 0 & 0 & 0 \\
\hline economie en maatschappij & ref. & ref. & ref. & ref. & ref. & ref. \\
\hline natuur en gezondheid & 0 & 0 & 0 & 0 & 0 & 0 \\
\hline natuur en techniek & - & 0 & 0 & 0 & 0 & 0 \\
\hline Profieloverstap & 0 & 0 & 0 & 0 & 0 & 0 \\
\hline Gemiddeld examencijfer & 0 & 0 & 0 & 0 & 0 & - \\
\hline \multicolumn{7}{|l|}{ Hoogst behaalde vooropleiding } \\
\hline geen & ref. & ref. & ref. & ref. & ref. & ref. \\
\hline havo & 0 & 0 & 0 & 0 & 0 & 0 \\
\hline anders & 0 & 0 & 0 & 0 & 0 & 0 \\
\hline Duur vwo opleiding & - & 0 & 0 & 0 & - & 0 \\
\hline \multicolumn{7}{|l|}{ Sector vervolgopleiding } \\
\hline landbouw & 0 & 0 & 0 & 0 & 0 & 0 \\
\hline onderwijs & 0 & 0 & 0 & 0 & - & + \\
\hline techniek & 0 & 0 & - & 0 & 0 & 0 \\
\hline economie & ref. & ref. & ref. & ref. & ref. & ref. \\
\hline gezondheidszorg & 0 & 0 & 0 & 0 & 0 & 0 \\
\hline gedrag en maatschappij & 0 & 0 & 0 & 0 & 0 & 0 \\
\hline taal en cultuur & 0 & 0 & 0 & 0 & 0 & 0 \\
\hline
\end{tabular}

ref. = referentie

- = negatief significant effect op 5\%-niveau

$0=$ geen significant effect op $5 \%$-niveau

$+=$ positief significant effect op $5 \%$-niveau 
Tabel $12 c$

Multivariate analyse van de kans dat schoolverlaters gebruik maken van de betreffende informatiebron

\begin{tabular}{|c|c|c|c|c|c|c|}
\hline VWO nieuwe stijl - WO & $\begin{array}{l}\text { Begelei- } \\
\text { ding op } \\
\text { school }\end{array}$ & $\begin{array}{c}\text { Open- } \\
\text { dagen } \\
\text { vervolg- } \\
\text { opleiding }\end{array}$ & $\begin{array}{l}\text { Meeloop- } \\
\text { dagen } \\
\text { vervolg- } \\
\text { opleiding }\end{array}$ & Folders & $\begin{array}{c}\text { Compu- } \\
\text { ters/ } \\
\text { internet }\end{array}$ & Anders \\
\hline \multicolumn{7}{|l|}{ Geslacht } \\
\hline vrouw & ref. & ref. & ref. & ref. & ref. & ref. \\
\hline man & 0 & - & - & - & 0 & 0 \\
\hline \multicolumn{7}{|l|}{ Profiel } \\
\hline cultuur en maatschappij & 0 & 0 & - & 0 & 0 & 0 \\
\hline economie en maatschappij & ref. & ref. & ref. & ref. & ref. & ref. \\
\hline natuur en gezondheid & 0 & - & - & - & 0 & + \\
\hline natuur en techniek & 0 & 0 & 0 & 0 & 0 & 0 \\
\hline Profieloverstap & 0 & 0 & 0 & 0 & + & 0 \\
\hline Gemiddeld examencijfer & 0 & + & + & + & 0 & 0 \\
\hline \multicolumn{7}{|l|}{ Hoogst behaalde vooropleiding } \\
\hline geen & ref. & ref. & ref. & ref. & ref. & ref. \\
\hline havo & 0 & 0 & 0 & 0 & 0 & 0 \\
\hline anders & 0 & 0 & 0 & 0 & 0 & 0 \\
\hline Duur vwo opleiding & - & 0 & 0 & - & 0 & 0 \\
\hline \multicolumn{7}{|l|}{ Sector vervolgopleiding } \\
\hline landbouw & 0 & 0 & 0 & 0 & 0 & 0 \\
\hline techniek & 0 & + & 0 & + & 0 & - \\
\hline economie & ref. & ref. & ref. & ref. & ref. & ref. \\
\hline gezondheidszorg & 0 & 0 & 0 & 0 & 0 & 0 \\
\hline gedrag en maatschappij & 0 & 0 & 0 & 0 & 0 & 0 \\
\hline taal en cultuur & 0 & 0 & 0 & 0 & 0 & 0 \\
\hline recht en openbare orde & 0 & 0 & 0 & 0 & 0 & 0 \\
\hline natuurwetenschappen & 0 & 0 & + & 0 & 0 & 0 \\
\hline
\end{tabular}

ref. = referentie

- = negatief significant effect op 5\%-niveau

$0=$ geen significant effect op $5 \%$-niveau

$+=$ positief significant effect op $5 \%$-niveau 
Tabel 13

Multivariate analyse van de kans dat schoolverlaters een bepaalde informatiebron het nuttigst vinden $^{1}$

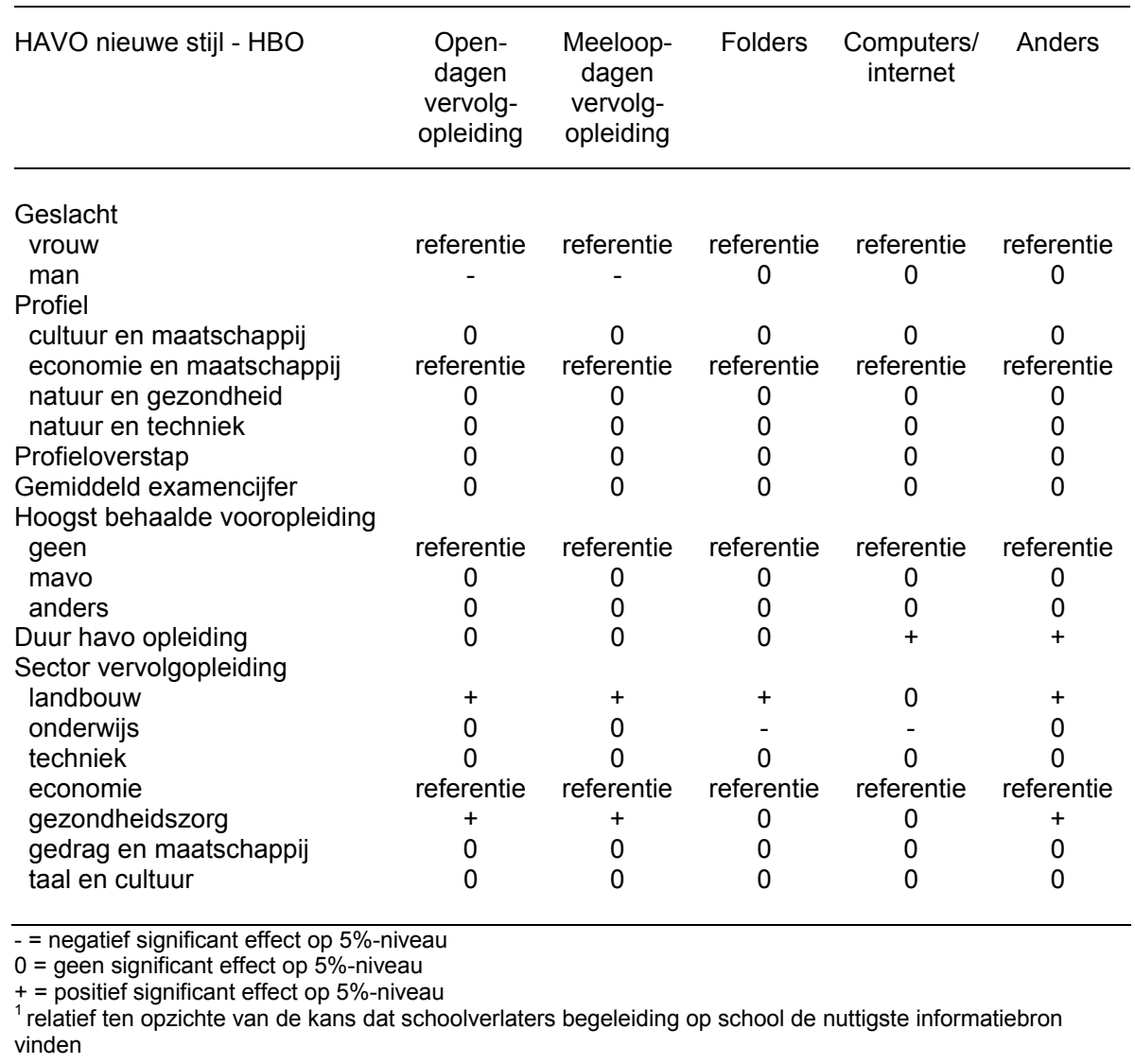


Tabel $13 b$

Multivariate analyse van de kans dat schoolverlaters een bepaalde informatiebron het nuttigst vinden ${ }^{1}$

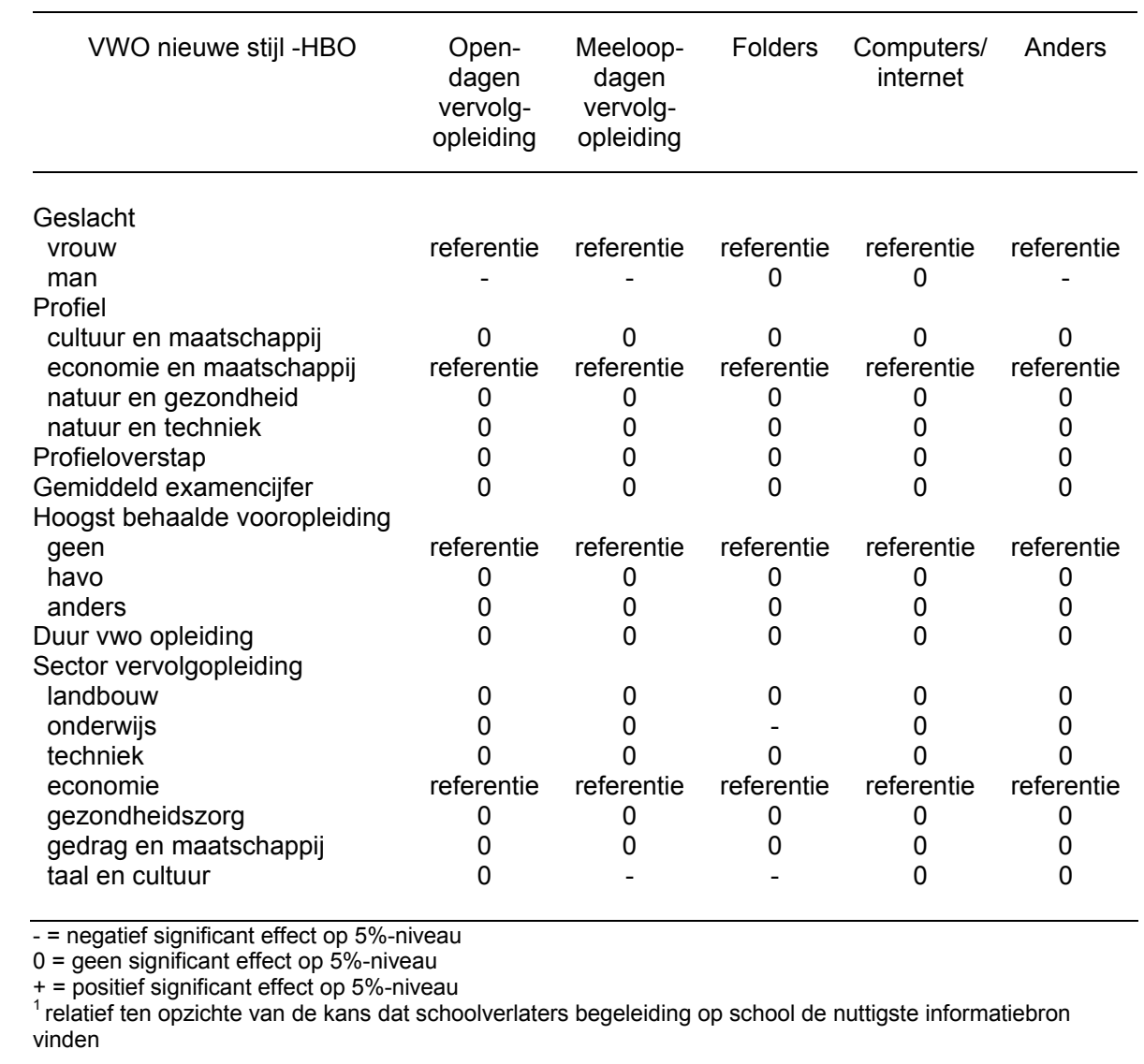


Tabel 13c

Multivariate analyse van de kans dat schoolverlaters een bepaalde informatiebron het nuttigst vinden $^{1}$

\begin{tabular}{|c|c|c|c|c|c|}
\hline VWO nieuwe stijl - WO & $\begin{array}{l}\text { Open- } \\
\text { dagen } \\
\text { vervolg- } \\
\text { opleiding }\end{array}$ & $\begin{array}{l}\text { Meeloop- } \\
\text { dagen } \\
\text { vervolg- } \\
\text { opleiding }\end{array}$ & Folders & $\begin{array}{l}\text { Computers/ } \\
\text { internet }\end{array}$ & Anders \\
\hline \multicolumn{6}{|l|}{ Geslacht } \\
\hline $\begin{array}{l}\text { vrouw } \\
\text { man }\end{array}$ & $\begin{array}{l}\text { referentie } \\
0\end{array}$ & $\begin{array}{c}\text { referentie } \\
-\end{array}$ & $\begin{array}{l}\text { referentie } \\
0\end{array}$ & $\begin{array}{l}\text { referentie } \\
0\end{array}$ & $\begin{array}{c}\text { referentie } \\
0\end{array}$ \\
\hline \multicolumn{6}{|l|}{ Profiel } \\
\hline cultuur en maatschappij & 0 & 0 & 0 & 0 & 0 \\
\hline economie en maatschappij & referentie & referentie & referentie & referentie & referentie \\
\hline natuur en gezondheid & 0 & 0 & 0 & 0 & 0 \\
\hline natuur en techniek & 0 & 0 & 0 & 0 & 0 \\
\hline Profieloverstap & 0 & 0 & 0 & 0 & 0 \\
\hline Gemiddeld examencijfer & 0 & 0 & 0 & - & 0 \\
\hline $\begin{array}{l}\text { Hoogst behaalde vooropleiding } \\
\text { geen }\end{array}$ & referentie & referentie & referentie & referentie & referentie \\
\hline havo & - & 0 & 0 & 0 & 0 \\
\hline anders & 0 & 0 & 0 & 0 & 0 \\
\hline Duur vwo opleiding & 0 & - & 0 & 0 & 0 \\
\hline \multicolumn{6}{|l|}{ Sector vervolgopleiding } \\
\hline landbouw & 0 & 0 & 0 & 0 & 0 \\
\hline techniek & 0 & 0 & 0 & 0 & 0 \\
\hline economie & referentie & referentie & referentie & referentie & referentie \\
\hline gezondheidszorg & + & 0 & 0 & 0 & 0 \\
\hline gedrag en maatschappij & 0 & 0 & 0 & 0 & 0 \\
\hline taal en cultuur & 0 & 0 & + & 0 & 0 \\
\hline recht en openbare orde & 0 & 0 & 0 & 0 & 0 \\
\hline natuurwetenschappen & 0 & 0 & 0 & 0 & 0 \\
\hline
\end{tabular}


Tabel 14

Multivariate analyse van de kans dat HAVO/VWO-schoolverlaters (zeer) tevreden zijn over de hulp die ze hebben gehad bij de keuze van een vervolgopleiding of een beroep

HAVO nieuwe stijl - VWO nieuwe stijl - VWO nieuwe stijl $\mathrm{HBO}$ $\mathrm{HBO}$ WO

Geslacht
vrouw
man
Profiel
cultuur en maatschappij
economie en maatschappij
natuur en gezondheid
natuur en techniek
Profieloverstap
Gemiddeld examencijfer
Hoogst behaalde vooropleiding
geen
mavo
havo
anders
Duur havo/vwo opleiding
Sector vervolgopleiding
landbouw
onderwijs
techniek
economie
gezondheidszorg
gedrag en maatschappij
taal en cultuur
recht en openbare orde
natuurwetenschappen

referentie

0

$+$

referentie

$+$

0

0

referentie

0

0

0

0

0

$+$

referentie

0

0

0

\# referentie

0

0

referentie

0

0

0

0

referentie

0

0

0

0

+
0

referentie

0

0

0

\# referentie

0

0

referentie

0

0

eferentie

0

0

0

\#

referentie

0

natuurwetenschappen

- = negatief significant effect op 5\%-nivea

$0=$ geen significant effect op 5\%-niveau

$+=$ positief significant effect op $5 \%$-niveau 